MARIANA GOMES LOURENÇO SIMÕES

SATISFAÇÃO NA EDUCAÇÃO À DISTÂNCIA EM UMA DISCIPLINA SEMI-

PRESENCIAL NA ÁREA DE SAÚDE 


\author{
UNIVERSIDADE DE BRASÍLIA \\ FACULDADE DE CIÊNCIAS DA SAÚDE \\ PROGRAMA DE GRADUAÇÃO EM CIÊNCIAS DA SAÚDE
}

MARIANA GOMES LOURENÇO SIMÕES

SATISFAÇÃO NA EDUCAÇÃO À DISTÂNCIA EM UMA DISCIPLINA SEMI-

PRESENCIAL NA ÁREA DE SAÚDE

Dissertação apresentada como requisito parcial para obtenção do Título de Mestre em Ciências da Saúde pelo Programa de Pós-Graduação em Ciências da Saúde da Universidade de Brasília - UnB.

Orientadora: Profa. Dra. Ana Paula Dias Ribeiro 


\title{
SATISFAÇÃO NA EDUCAÇÃO À DISTÂNCIA EM UMA DISCIPLINA SEMI- PRESENCIAL NA ÁREA DE SAÚDE
}

Dissertação apresentada como requisito parcial para obtenção do Título de Mestre em Ciências da Saúde pelo Programa de Pós-Graduação em Ciências da Saúde da Universidade de Brasília - UnB.

Aprovada em 02 de março de 2016.

\section{BANCA EXAMINADORA}

\author{
Profa. Dra. Ana Paula Dias Ribeiro \\ Universidade de Brasília
}

Profa. Dra. Soraya Coelho Leal Universidade de Brasília

Prof. Dr. Adriano de Almeida Lima Universidade de Brasília

Profa. Dra. Fernanda Cristina Pimentel Garcia Universidade de Brasília 
Trabalho realizado sob a orientação da Profa. Dra. Ana Paula Dias Ribeiro. As pesquisas foram realizadas via e-mail com alunos de graduação da área de saúde matriculados na disciplina Tópicos Avançados em Promoção e Saúde - TAPS na Universidade de Brasília. 
A Deus, por todo o auxílio bem presente, pelos ensinamentos contínuos, por todo o refrigério encontrado no momento oportuno e pela força, coragem e ânimo para seguir os Seus caminhos.

Aos meus queridos pais, Mércio e Helena, por me amarem incondicionalmente e me ensinarem a valorizar o seu sacrifício, para que eu alcançasse as minhas vitórias.

Ao meu companheiro, Marcelo Simões, por me mostrar que eu era capaz, pela sua paciência, por compreender a minha ausência e por ser meu ombro amigo em todos os momentos. Seu apoio e presença foram imprescindíveis para a realização deste sonho.

À minha filha querida, Ana Beatriz, que, mesmo sendo pequenina, compreendeu de forma gigante as minhas ausências. 
À Profa. Dra. Ana Paula Dias Ribeiro, minha incansável orientadora, que me recebeu com todo o carinho, paciência e compreensão. Obrigada por me orientar e me fazer alcançar esta vitória.

Ao meu amado Prof. Dr. Elioenai Dornelles Alves (in memorium), que me apoiou e me incentivou, mesmo em meio às suas próprias dificuldades, e me deixou um legado de paciência, competência e admiração.

Ao amigo Ms. André Ribeiro, meu colega de UnB, por seu auxílio, que foi indispensável para minha caminhada.

Ao meu cunhado Luís Horácio Sabóia Vieira, por ter me ensinado o caminho das pedras, para um dia alcançar algo que nunca imaginava que fosse capaz. Luís, esta vitória é sua também.

À Cláudia Emir Vieira Galante, por suas correções e ensinamentos durante esta jornada, e ao Alexandre Dídimo Sumizono Vieira, que chegou ao final do trabalho, mas seu auxílio e paciência foram indispensáveis para a concretização deste sonho.

À minha família, Mércio, Helena, Mércia, Edson, Rafael, Ana Paula, Monique, Luís, Giovana, Gabriela, Marco, Hérica, Ana Carolina, Bruno Henrique, Marcelo e Ana Beatriz, por toda a compreensão nos momentos de ansiedade, desesperos, lágrimas, ausências, mas também de alegrais, risadas e brincadeiras.

À secretária de Pós-graduação Edigrês Alves de Sousa, pela solicitude em todos os momentos burocráticos do curso, desde o início até o final.

Ao programa de Pós-graduação em Ciências da Saúde da Universidade de Brasília, na pessoa da atual coordenadora, Eliete Neves, pela oportunidade de formação profissional.

A todos que de alguma forma contribuíram direta ou indiretamente para a realização deste trabalho. 
"Aprender é a única coisa de que a mente nunca se cansa, nunca tem medo e nunca se arrepende."

(Leonardo da Vinci) 


\section{RESUMO}

A Educação à Distância $(\mathrm{EaD})$ cresce no Brasil com credibilidade, incentivada pelo uso das Novas Tecnologias de Comunicação e Informação (NTCls). Considerandose que $\mathrm{EaD}$ é uma tendência no mundo contemporâneo, o profissional de saúde, mais do que qualquer outro, deve dela se utilizar e procurar permanentemente atualizar suas competências técnicas e tecnológicas, sociais e culturais, em respeito aos princípios éticos que regem a sua conduta, de modo que esteja em condições de prestar os melhores cuidados de saúde à população. A satisfação do aluno de $\mathrm{EaD}$ foi um indicador de qualidade encontrado por meio dos resultados obtidos. Os participantes foram alunos da Universidade de Brasília de cursos na área de saúde, matriculados na disciplina semipresencial: Tópicos Avançados em Promoção e Saúde - TAPS, que responderam a um questionário de avaliação de satisfação da EaD em relação à aprendizagem, contendo perguntas sobre as seguintes dimensões: Aluno, Professor, Tutor, Ambiente do Curso/Interação, Curso/Disciplina, Avaliação e Satisfação. Os resultados foram submetidos a uma análise descritiva e estatística, utilizando-se o teste de Fisher para a análise bivariada e regressão logística para formulação de um modelo multivariado com níveis de significância de 0,05 . Os resultados indicaram uma satisfação de aproximadamente $95 \%$, e a dimensão Aluno foi a única capaz de estabelecer um modelo de regressão significativo, com cerca de $56 \%$ da variável satisfação. Entre os pontos considerados facilitadores, a flexibilidade de horário foi o mais comumente citado, seguido pela flexibilidade do local de realização das atividades e fácil acesso ao material didático/conteúdo da disciplina. Em relação aos pontos considerados dificultadores do processo ensino-aprendizagem, a pequena interação entre alunos, docentes e tutores foi o mais citado. Dessa forma, foi possível concluir que a insatisfação quanto à disciplina semipresencial estava mais relacionada à dimensão Aluno e que são necessárias medidas para aumentar a interação entre professores, tutores e alunos, a fim de elevar a qualidade do processo ensino-aprendizagem de disciplinas que usam EaD. 
Palavras-chaves: Educação à Distância, Saúde Pública, Melhoria de Qualidade, Educação Superior, Satisfação do Usuário. 


\begin{abstract}
The Distance Education (DE) grows in Brazil with credibility, encouraged by the use of new Information and Communication Technologies (NICT). Whereas DE is a tendency in the contemporary world, health professionals, more than any other, should use it and seek constantly to update their technical and technological, social and cultural skills in regard to the ethical principles governing their conduct, so that they are able to provide the best health care to the population. The satisfaction of distance education student has a quality indicator found by the results obtained. Participants were students at the University of Brasilia courses in health, enrolled in blended course: Advanced Topics in Health Promotion (TAPS), who answered a questionnaire evaluating satisfaction of Distance Education in relation to learning, containing questions about the following dimensions: Student, Teacher, Tutor, Environment Course / Interaction, Course / Discipline, Evaluation and Satisfaction. The results were submitted to a descriptive and statistical analysis using the Fisher test for bivariate analysis and logistic regression to formulate a multivariate model with 0.05 significance level. The results indicated a satisfaction of approximately $95 \%$, and the dimension Student was the only one to establish a significant regression model, with about $56 \%$ of the variable satisfaction. Among the issues considered facilitators, the schedule flexibility was the most commonly cited, followed by the flexibility of the place of carrying out these activities and easy access to courseware/content of the discipline. Concerning the points considered hindering the teaching-learning process, the little interaction between students, teachers and tutors was the most cited. Thus, it was concluded that the dissatisfaction with the blended discipline was more related to the dimension Student and that measures are needed to increase the interaction between teachers, tutors and students to improve the quality of the teaching-learning process of disciplines using Distance Education.
\end{abstract}

Keywords: Distance Education, Public Health, Quality Improvement, Higher Education, Consumer Behavior. 


\section{LISTA DE QUADROS}

Quadro 1: Componentes essenciais e suas definições na EaD.

Quadro 2: Gerações de EaD.

Quadro 3: Questionário aplicado. 


\section{LISTA DE ILUSTRAÇÕES}

Figura 1: Interface do NESPROM.

Figura 2: Interface mostrando os cursos em EaD na plataforma NESPROM.

Figura 3: Interface da disciplina TAPS.

Figura 4: Interface da disciplina TAPS indicando os tópicos.

Figura 5: Interface da disciplina TAPS indicando a oficina 1.

Figura 6: Interface da disciplina TAPS indicando a oficina 6.

Figura 7: Fluxograma das oficinas de TAPS, oficinas 1 a 3.

Figura 8: Fluxograma das oficinas de TAPS, oficinas 4 a 6.

Figura 9: Dimensões propostas na percepção da satisfação da disciplina semipresencial TAPS.

Figura 10: Gênero dos participantes da pesquisa.

Figura 11: Gráfico em barras representando a frequência (\%) da faixa etária.

Figura 12: Frequência (\%) do estado civil dos respondentes.

Figura 13: Quantidade de filhos dos respondentes (\%).

Figura 14: Frequência (\%) dos cursos da área de saúde dos respondentes.

Figura 15: Gráfico em barras representando a frequência de alunos nos semestres de realização da disciplina TAPS.

Figura 16: Frequência (\%) dos locais de estudo dos respondentes. 


\section{LISTA DE TABELAS}

Tabela 1: Análise descritiva da dimensão Aluno.

Tabela 2: Análise estatística da dimensão Aluno em relação à variável satisfação, utilizando-se o teste exato de Fisher $(\alpha=0,05)$.

Tabela 3: Regressão logística multivariada da dimensão Aluno na variável satisfação.

Tabela 4: Análise descritiva da dimensão Professor.

Tabela 5: Análise estatística da dimensão Professor em relação à variável satisfação, utilizando-se o teste exato de Fisher $(\alpha=0,05)$.

Tabela 6: Regressão logística multivariada da dimensão Professor na variável satisfação.

Tabela 7: Análise descritiva da dimensão Tutor.

Tabela 8: Análise estatística da dimensão Tutor em relação à variável satisfação, utilizando-se o teste exato de Fisher $(\alpha=0,05)$.

Tabela 9: Regressão logística multivariada da dimensão Tutor na variável satisfação.

Tabela 10: Análise descritiva da dimensão Ambiente do Curso/Interação.

Tabela 11: Análise estatística da dimensão Ambiente do Curso/Interação em relação à variável satisfação, utilizando-se o teste exato de Fisher $(\alpha=0,05)$.

Tabela 12: Regressão logística multivariada da dimensão Ambiente do Curso/Interação na variável satisfação.

Tabela 13: Análise descritiva da dimensão Curso/Disciplina.

Tabela 14: Análise estatística da dimensão Curso/Disciplina em relação à variável satisfação, utilizando-se o teste exato de Fisher $(\alpha=0,05)$.

Tabela 15: Regressão logística multivariada da dimensão Curso/Disciplina na variável satisfação.

Tabela 16: Análise descritiva da dimensão Avaliação. 
Tabela 17: Análise estatística da dimensão Avaliação em relação à variável satisfação, utilizando-se o teste exato de Fisher $(\alpha=0,05)$.

Tabela 18: Análise descritiva da dimensão Satisfação.

Tabela 19: Análise estatística da dimensão Satisfação em relação à variável satisfação, utilizando-se o teste exato de Fisher $(\alpha=0,05)$.

Tabela 20: Regressão logística multivariada da dimensão Satisfação na variável satisfação. 


\section{LISTA DE ABREVIATURAS E SIGLAS}

ABED - Associação Brasileira de Educação à Distância.

AVA - Ambiente Virtual de Aprendizagem.

Cibercultura - Conjunto de Técnicas (materiais e intelectuais).

CMS - Course Management System.

EaD - Educação à Distância.

EUA - Estados Unidos da América.

IBGE - Instituto Brasileiro de Geografia e Estatística.

IC - Intervalo de Confiança.

IGC - Índice Geral de Cursos.

INPE - Instituto Nacional de Pesquisas Espaciais.

Interfarma - Associação da Indústria Farmacêutica de Pesquisa.

LDB - Lei de Diretrizes e Bases da Educação Nacional.

LMS - Learning Management System.

MEC - Ministério da Educação.

Moodle - Modular Object-Oriented Dynamic Learning Environment.

NESPROM - Núcleo de Estudos em Educação e Promoção à Saúde.

NTCls - Novas Tecnologias de Comunicação e Informação.

OCDE - Organização para a Cooperação e o Desenvolvimento Econômico.

OD - odds-ratio (razão de chance).

PNADs - Pesquisa Nacional por Amostra de Domicílios.

SGC - Sistema Gerenciador de Curso ou Plataforma virtual.

SUS - Sistema Único de Saúde. 
TAPS - Tópicos Avançados em Promoção e Saúde.

TCLE - Termo de Consentimento Livre e Esclarecido.

UAB - Sistema Universidade Aberta do Brasil.

UnB - Universidade de Brasília.

Unesco - Organização das Nações Unidas para a Educação, Ciência e Cultura.

VLE - Virtual Learning Environment.

Web - Teia ou Rede. 


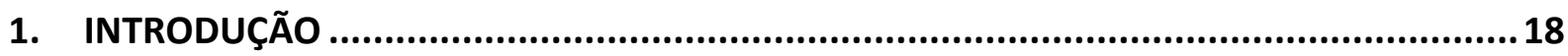

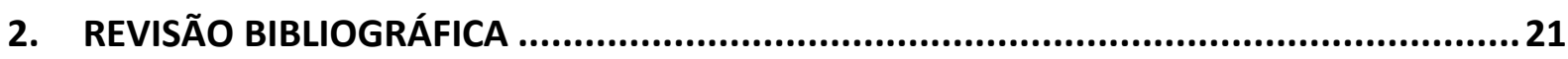

2.2. ENSINO SUPERIOR ........................................................................................... 21

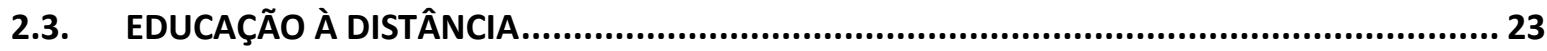

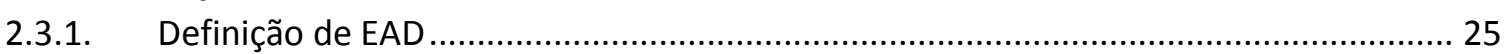

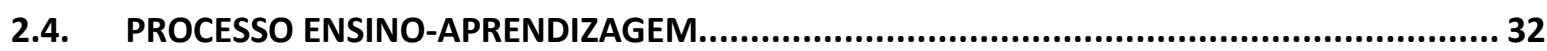

2.4.1. Processo Ensino-Aprendizagem na EAD .............................................................. 33

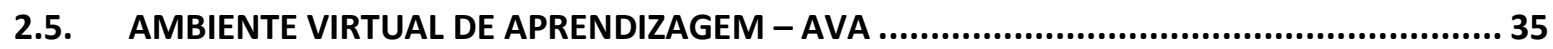

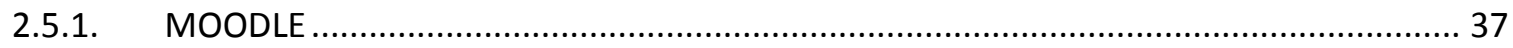

2.5.2. NESPROM (Núcleo de Estudos em Educação e Promoção à Saúde)............................... 41

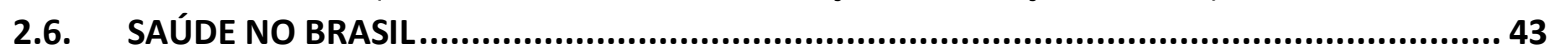

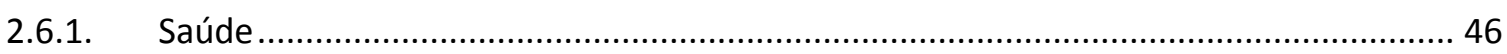

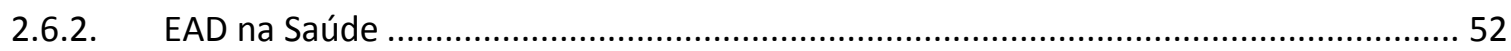

2.7. DEFINIÇÕES DE PESQUISA QUALITATIVA E QUANTITATIVA.........................................5 54

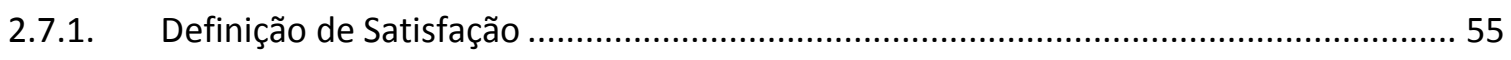

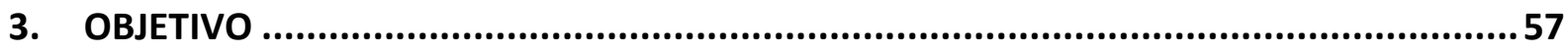

4. METODOLOGIA.................................................................................................58

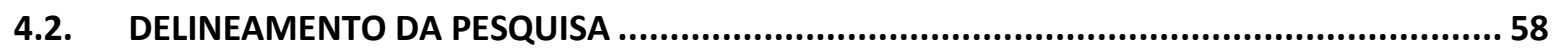

4.3. DESCRIÇÃO DA DISCIPLINA TÓPICOS AVANÇADOS EM PROMOÇÃO E SAÚDE...................59

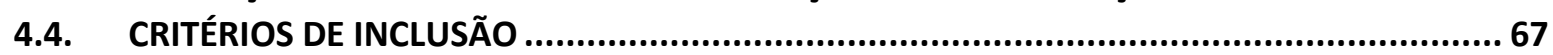

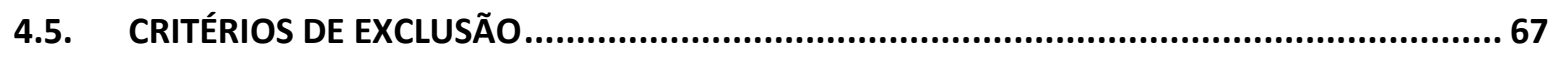

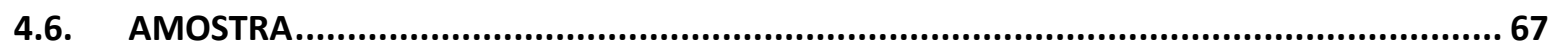

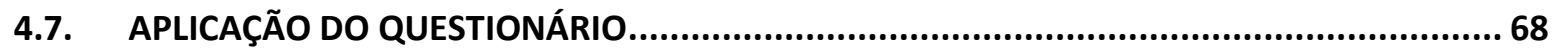

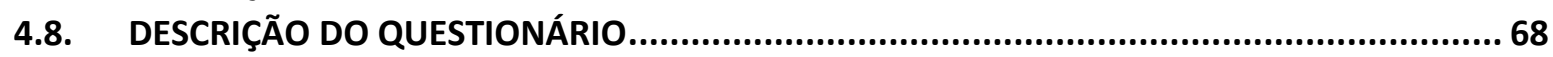

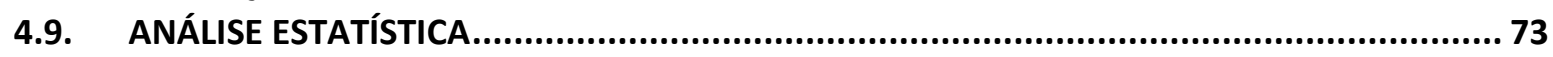

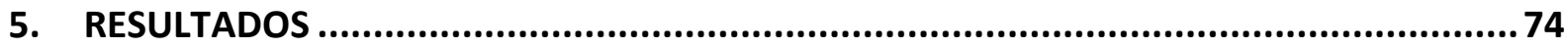

5.2. PERFIL DOS ALUNOS PARTICIPANTES DA DISCIPLINA TAPS .......................................74

5.3. ANÁLISE DESCRITIVA E ESTATÍSTICA DOS COMPONENTES DA DIMENSÃO ALUNO...........78

5.4. ANÁLISE DESCRITIVA E ESTATÍSTICA DOS COMPONENTES DA DIMENSÃO PROFESSOR ... 81

5.5. ANÁLISE DESCRITIVA E ESTATÍSTICA DOS COMPONENTES DA DIMENSÃO TUTOR ............84

5.6. ANÁLISE DESCRITIVA E ESTATÍSTICA DOS COMPONENTES DA DIMENSÃO AMBIENTE DO

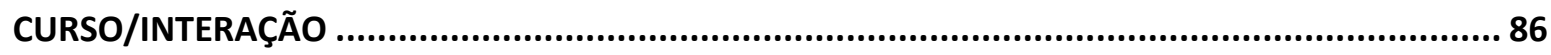

5.7. ANÁLISE DESCRITIVA E ESTATÍSTICA DOS COMPONENTES DA DIMENSÃO

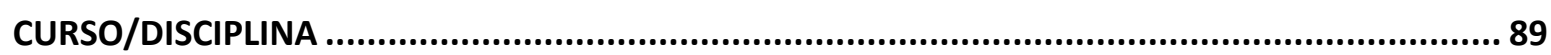

5.8. ANÁLISE DESCRITIVA E ESTATÍSTICA DOS COMPONENTES DA DIMENSÃO AVALIAÇÃO... 92 5.9. ANÁLISE DESCRITIVA E ESTATÍSTICA DOS COMPONENTES DA DIMENSÃO SATISFAÇÃO... 94 5.10. ASPECTOS FACILITADORES E DIFICULTADORES DO PROCESSO DE ENSINO-

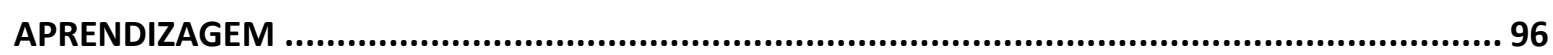

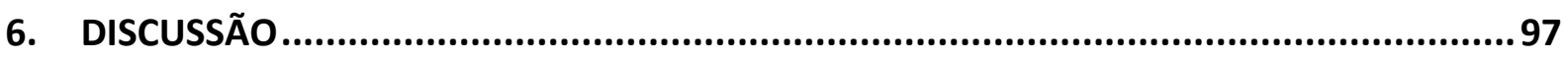

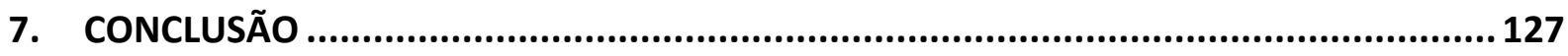

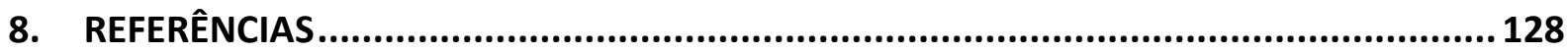




\section{INTRODUÇÃO}

A educação é o elemento principal na construção de uma sociedade fundamentada na informação, no conhecimento e no aprendizado. É utilizada pela sociedade como meio de auxiliar o ser humano a alcançar seu potencial máximo de conhecimento, estimulando-o a colaborar com outros em ações que visam ao bem comum. O Michaelis Dicionário Brasileiro da Língua Portuguesa define educação como "Ato ou efeito de educar; aperfeiçoamento das faculdades físicas intelectuais e morais do ser humano; disciplinamento, instrução, ensino; processo pelo qual uma função se desenvolve e se aperfeiçoa pelo próprio exercício". Sabe-se que parte da desigualdade presente na sociedade brasileira se deve à má distribuição de oportunidades ao desenvolvimento da capacidade de aprender e concretizar algo novo. (ARIEIRA, 2009)

Inicialmente, o uso da Educação à Distância $(\mathrm{EaD})$ foi apontado como a grande solução para resolver a crise de analfabetismo de nosso País. Com o passar do tempo, entretanto, percebeu-se que esse tipo de educação não deveria ser usado somente para esse propósito, mas também poderia ser usado para promover a educação nas diversas fases, locais e culturas. (MACHADO, 2010)

A EaD se define como um tipo de educação planejada que leva o aluno a aprender de forma não convencional. Acontece em um lugar físico diferente do local de ensino, exigindo técnicas especiais de criação do curso e de instrução e comunicação por meio de várias tecnologias e disposições organizacionais e administrativas especiais. (MOORE \& KEARSLEY, 2007)

Representa uma modalidade de ensino que está se destacando no cenário atual, principalmente porque se adapta a diferentes realidades dos alunos que procuram formação e especialização nestes dias conturbados. Compreende um sistema que atende às necessidades de um público específico, atingindo cada vez mais segmentos. Não se trata, portanto, de uma forma facilitada de conseguir títulos, muito menos de formação de baixa qualidade. Há relatos de que as matérias realizadas utilizando-se o Moodle - Modular Object-Oriented Dynamic Learning Environment têm sido mais difíceis, trabalhosas, se comparadas às matérias presenciais. (MEZZARI, 2012) 
Esse crescimento da $\mathrm{EaD}$ é visto como uma grande conquista no ramo educacional, uma vez que a educação tem um importante papel na construção da convicção, conhecimento e atitudes da nova geração de profissionais, de forma democrática. (ABREU, 2010)

Azevedo (2000), apud Malacrida, 2011, diz que uma vantagem da EaD é a flexibilidade, porque não está limitada às condições espaciais e temporais da sala de aula, que obrigam tutor e aluno a se encontrarem em um mesmo momento, e também porque proporciona a todos a condição de usufruírem o direito de acesso ao conhecimento, gerando inclusão independentemente das limitações.

Visto que a EaD é uma tendência no mundo contemporâneo, e a sua principal vantagem a flexibilidade, o profissional de saúde, mais do que qualquer outro, deve dela se utilizar, procurando permanentemente atualizar suas competências técnicas, tecnológicas, sociais e culturais, isso em respeito aos princípios éticos que regem a sua conduta, de modo que esteja em condições de prestar os melhores cuidados de saúde à população.

Levando-se em consideração as dificuldades enfrentadas por profissionais de saúde que atuam em diversas áreas do saber no serviço público e privado, a EaD representa uma excelente estratégia para a educação permanente e contínua, com o auxílio de novas tecnologias. (OLIVEIRA, 2007). Dessa forma, a EaD passa a ser uma ferramenta de grande importância para levar os profissionais da área de saúde a desenvolver a competência continuada, adquirindo conhecimentos atualizados. (SANTOS, 2012)

A união de Novas Tecnologias de Informação e Comunicação (NTICs) com a EaD tem um papel importante na formação permanente e imediata do profissional de saúde, atendendo às suas necessidades e desenvolvendo projetos significativos para o seu aperfeiçoamento em um processo de ação e reação, tornando-se uma ferramenta de grande valia principalmente para o Sistema Único de Saúde - SUS no Brasil. (ABREU, 2010).

As instituições de ensino superior têm se ajustado e incluído o uso da $\mathrm{EaD}$ em sua grade curricular, buscando o aprimoramento e o crescimento da EaD como um processo de ensino-aprendizagem sólido e fundamentado. Para Kubo e Botomé, 2001, o processo de ensino-aprendizagem é um complexo sistema de interações comportamentais entre professores e alunos, em que se adquire conhecimento por meio de trocas constantes de conteúdo e experiências. 
Satisfação, segundo Kotler, 2007, consiste em sensações de prazer ou desprazer resultantes de uma comparação feita pelo próprio aluno em relação ao desempenho do produto, tornando-se um indicador de qualidade, sendo ainda a responsável pela geração de resultados de aprendizagem e qualidade do curso prestado. (Marks, Sibley e Arbaugh, 2005).

Então, a busca pela satisfação do aluno, que implica qualidade do curso, é considerada hoje a maior preocupação das organizações públicas e privadas, que buscam novas estratégias e avanços para alcançar um ensino de excelência, resultando em maior crescimento no mercado. (OLIVEIRA, 2007)

Visto isso, e considerando-se os problemas da área de saúde no nosso País, fazem-se indispensáveis estudos aprofundados sobre a satisfação do aluno que resulte em qualidade de um curso à distância nessa área. A atualização do profissional deverá atender às preocupações de falta ou defasagem de conhecimento, com resultados diretos na saúde pública.

Essas informações nos levaram a questionar se existe satisfação dos alunos na aprendizagem do conteúdo viabilizado na $\mathrm{EaD}$ na área de saúde na Universidade de Brasília, Distrito Federal, em uma matéria semipresencial, de modo que os alunos se tornem competentes e aptos, dando-lhes oportunidade durante e após a formação acadêmica.

A pergunta norteadora desta dissertação foi: Existe satisfação de aprendizagem dentro da EaD na área de saúde?

Esta dissertação tem a expectativa de observar a satisfação de alunos da área de saúde com a qualidade do aprendizado no padrão atual de ensino à distância de uma disciplina semipresencial. Essa avaliação foi fundamentada por meio de pesquisa bibliográfica em sítios eletrônicos e artigos, e utilizada a metodologia de aplicação de um questionário de avaliação do sujeito interessado e respectiva autoavaliação. 


\section{REVISÃO BIBLIOGRÁFICA}

Nos capítulos a seguir, está colocado todo o aporte teórico que foi utilizado como sustentação desta pesquisa, tendo como objetivo auxiliar o pesquisador e o leitor na sua compreensão, permitindo a análise e a comparação dos resultados obtidos.

\subsection{ENSINO SUPERIOR}

O real significado do termo "Ensino Superior" vai muito além do de ensino de terceiro grau, como ficou popularizado, principalmente após as reformas das décadas de 60 e 70.0 saber superior deve ser adquirido mediante o uso de codificações, sistemas, modelos e símbolos da semântica científica e, por isso, foge à praticidade do dia a dia e se reserva aos que disponham de condições especiais para abordá-lo. (Estrutura e Funcionamento do Ensino Superior Brasileiro - Paulo Nathanael P. Souza,1991).

As primeiras universidades surgiram durante o século $\mathrm{V}$, período da Idade Média, principalmente na Europa. O conhecimento era então restrito e sempre ligado à Igreja ou à Corte real. Entretanto, durante o século XV surgiram Universidades Modernas no Ocidente medieval por causa das modificações realizadas devido aos questionamentos que foram levantados sobre os ensinos anteriores, em que não existiam divisões das matérias teóricas existentes, no Direito, Medicina, Política, Educação e Teologia. (OLIVEIRA, 2012). Uma vez que este movimento de reforma começou foi se espalhando pelo norte da Europa e nos Estados Unidos da América, o que levou ao início de instituições não ligadas à Igreja ou a Corte. (OLIVEIRA, 2012).

No Brasil o ensino superior começou a surgir em 1808, com a vinda da Família Real, por meio da criação de escolas médicas na Bahia e Rio de Janeiro. Em 1912, com a vinda da Família Imperial, vieram as instituições culturais e científicas, que levaram à criação de Universidades no país. Mas, ainda assim, não 
eram consideradas universidade brasileira, já que para todos os efeitos era um estabelecimento Português em território Brasileiro. (SOFFNER, 2010)

Já na década de 50 a 70, foram criadas universidades federais em todo 0 Brasil. Cada estado tinha ao menos uma, além das estaduais, municipais e particulares. Com o surgimento de tantas universidades, se fez necessária a criação da Lei de Diretrizes e Bases da Educação Nacional, por João Goulart, legislação que regulamenta o sistema educacional (público e privado) do Brasil até os dias de hoje. A LDB entrou em vigor a partir de 1961 (LDB 4.024/61) e, em 1996 (LDB 9.394/96), sofreu algumas modificações: as leis foram reformuladas e novamente regulamentadas. (SOFFNER, 2010)

Durante a década de 70, houve aumento da concentração de mão de obra urbana, o que levou à exigência de mão de obra qualificada, causando grande procura por ensino superior. O número de matrículas subiu muito, fazendo com que o Governo permitisse que o Conselho Federal de Educação aprovasse milhares de novos cursos. (SOFFNER, 2010)

Com o passar dos anos, o ensino superior cresceu rapidamente e hoje é considerado uma qualificação indispensável para o mercado de trabalho. Com o aumento da procura, fez-se necessária a diversificação da sua oferta. Dessa forma, o Ministério da Educação - MEC definiu que o ensino superior pode e deve ser ministrado nas seguintes modalidades:

$\rightarrow$ Presencial: a presença do aluno é exigida em, pelo menos, $75 \%$ das aulas e todas as avaliações são presenciais.

$\rightarrow$ À Distância (EaD): não há relação presencial entre professor-aluno, o processo de ensino acontece por meio de NTICs, material impresso e on-line. 


\subsection{EDUCAÇÃO À DISTÂNCIA}

A Educação à Distância (EaD) é uma modalidade educativa amplamente recomendada, que, a partir da década de 1990, encontrou campo fértil de desenvolvimento no Estado brasileiro (SANTOS, 2008) e tem crescido no Brasil com credibilidade, incentivada pelas possibilidades decorrentes das Novas Tecnologias de Informação e Comunicação (NTICs) em todos os níveis de graduação. (ABREU, 2010)

A revolução da tecnologia e suas consequências estão determinando uma nova ordem econômica e social nos mais variados campos da vida humana e não poderia deixar de ser assim também na área de educação. (NUNES, 1992). A rápida globalização, que aconteceu no mundo nos últimos anos, levou à necessidade de uma educação permanente e contínua, sendo isso possível somente por meio dos cursos à distância que incorporam e lançam mão dos avanços tecnológicos. (LARA, 2009)

A EaD apresenta elementos indispensáveis desde a sua concepção até o uso deste tipo de ensino. A sua forma de aplicabilidade é de grande valia nos dias de hoje, pois os maiores obstáculos encontrados pelos alunos são a separação física entre professor e aluno e a inflexibilidade temporal. (SANAVRIA, 2008)

Fazem parte da EaD os seguintes componentes essenciais e suas definições: 
Quadro 1 - Componentes essências e suas definições na EaD, de acordo com Marcuzzo, 2013.

\begin{tabular}{|c|c|}
\hline Componentes essenciais & Definições \\
\hline Ambiente- $\rightarrow$ & $\begin{array}{l}\text { Local que proporciona a interação } \\
\text { instantânea ou não dos alunos, } \\
\text { professores, tutores e monitores. }\end{array}$ \\
\hline Professor $\rightarrow$ & $\begin{array}{l}\text { Apresenta-se como um facilitador desse } \\
\text { processo de ensino, juntamente com } \\
\text { sua eficácia e forma de ensinar, ainda } \\
\text { que seja através de pouco contato físico } \\
\text { ou nenhum. }\end{array}$ \\
\hline Tutor $\rightarrow$ & $\begin{array}{l}\text { Pessoa responsável por facilitar a } \\
\text { operação de todas as ferramentas do } \\
\text { sítio eletrônico, observar a atividade do } \\
\text { aluno on-line, corrigir as postagens e } \\
\text { trabalhos e, principalmente, motivar a } \\
\text { turma, trazendo um toque pessoal e } \\
\text { humano. }\end{array}$ \\
\hline Componentes essenciais & Definições \\
\hline Monitor $\rightarrow$ & $\begin{array}{l}\text { Deve ser uma pessoa segura e } \\
\text { conhecedora do conteúdo para tirar } \\
\text { dúvidas, corrigir exercícios e interagir } \\
\text { ativamente com os alunos sempre } \\
\text { dando um feedback. }\end{array}$ \\
\hline Aluno $\rightarrow$ & $\begin{array}{l}\text { Esse é o elemento principal e essencial } \\
\text { no processo de aprendizagem, levando } \\
\text { todos os outros a terem a preocupação } \\
\text { de buscar a sua motivação, levando-o a } \\
\text { adquirir habilidades de analisar e aplicar } \\
\text { o conteúdo aprendido. }\end{array}$ \\
\hline
\end{tabular}

Claro que a organização educacional e a utilização das Novas Tecnologias de Informação e Comunicação (NTICs) influenciam quase que exclusivamente o crescimento expressivo dessa nova forma de ensino, diminuindo essa distância e facilitando a transmissão de conteúdos educativos, independentemente do local que o alunado esteja: em casa, trabalho ou até em uma sala de estudo de apoio. Essa melhoria na forma de transmitir a informação educacional faz com que o processo de aprendizagem se desenvolva naturalmente independentemente do ambiente, levando assim à melhoria da capacitação dos profissionais, dando liberdade e livre acesso aos estudos. (LARA, 2009) 


\subsubsection{Definição de EAD}

Ao longo da história, a Educação à Distância foi conceituada de várias formas. Portanto, não há uma única definição. As diferentes definições dadas aos constituintes do processo de ensino-aprendizagem juntamente com as mídias utilizadas no ensino à distância levaram a chamá-la de Educação à Distância, contribuindo assim para a construção das diversas definições dessa modalidade de ensino. (SOFFENER, 2010)

No sítio eletrônico http://www.educabrasil.com.br/eb/dic/dicionario.asp?id=328 se define Educação à Distância como um processo de ensino-aprendizagem, em que professores e alunos não estão normalmente juntos, fisicamente, mas podem estar conectados, interligados por tecnologias impressas (livros, apostilas, jornais), sonoras (rádio, fitas cassete), audiovisuais (TV, vídeo, CD-ROM) e telemáticas (internet).

A EaD é o aprendizado planejado que ocorre normalmente em um lugar diferente do local do ensino, exigindo técnicas especiais de criação do curso e de instrução, comunicação, por meio de várias tecnologias e disposições organizacionais e administrativas especiais. (MOORE \& KEARSLEY, 2007)

Pode também ter ou não momentos presenciais como a $\mathrm{EaD}$ semipresencial. O ensino à distância abrange as formas de estudo que não são dirigidas e/ou controladas pela presença do professor/tutor na aula, ainda que os alunos se beneficiem do planejamento, orientação e ensinamentos de professores-tutores, ou de algum meio de comunicação social que permite a interação entre tutor e aluno.

Partindo desses princípios, a EaD foi definida pelo art. $1^{\circ}$ do Decreto 5.562/2005 como uma modalidade de ensino na qual a mediação didática e pedagógica nos processos de ensino e aprendizagem ocorre com a utilização de meios e tecnologias de informação e comunicação, com estudantes e professoresltutores desenvolvendo atividades educativas em lugares ou tempos diferentes. (Art. $1^{\circ}$ do Decreto 5.562, de 19 de dezembro de 2005) 
Todas essas definições se completam, chegando-se à conclusão de que a EaD é o meio de comunicação mais adequado e essencial para a geração do século 21, com a ideia principal de que a EaD possa permitir o acesso ao aprendizado e dar maior autonomia ao aluno, sem nenhuma restrição.

Diferentes autores organizaram as várias fases da $\mathrm{EaD}$, no que se convencionou chamar de "gerações de EaD". Como não há um consenso do que caracterizaria todas as etapas, com exceção da primeira e segunda geração, Rosemary Soffner (2010) criou um quadro com uma síntese dessas gerações, do que julgaram ser uma das possíveis organizações, e Santos explicou a quinta geração.

Quadro 2 - Gerações da EaD.

\begin{tabular}{|l|l|}
\hline \multicolumn{1}{|c|}{ Geração } & \multicolumn{1}{|c|}{ Recursos ou mídias } \\
\hline $1^{\text {a }}$ Geração & $\begin{array}{l}\text { material impresso - ensino por } \\
\text { correspondência }\end{array}$ \\
\hline $2^{2}$ Geração & $\begin{array}{l}\text { material impresso, rádio e televisão - rádio } \\
\text { educação e tele-educação }\end{array}$ \\
\hline $3^{\text {a }}$ Geração & $\begin{array}{l}\text { computadores - educação assistida por } \\
\text { computadores }\end{array}$ \\
\hline $4^{\underline{a}}$ Geração & WEB - educação on-line, e-learning. \\
\hline $5^{\text {a }}$ Geração & $\begin{array}{l}\text { NTICs - uso acelerado para todos com } \\
\text { diminuição dos vieses anteriores. (Santos, } \\
\text { 2008) }\end{array}$ \\
\hline
\end{tabular}

Fonte: SOFFNER, 2010, pág. 49 adaptado.

A primeira geração ficou caracterizada pelo uso de correspondência por meio de cartas. Surgiu em meados do século XIX e fez muitos adeptos, porém só foi até os anos 60. Já no início do século $X X$, a EaD foi sustentada e impulsionada pela expansão dos correios. O fruto da Revolução Industrial na época tinha como demanda o desenvolvimento e aprimoramento de adultos com o treinamento profissional, por meio de cursos técnicos para a nova força de trabalho, além da alfabetização de comunidades rurais. (SANTOS, 2008) 
Por meio de material impresso como apostilas, manuais, folhetos entre outros, os conteúdos eram abordados de maneira rudimentar, praticamente uma réplica do ensino presencial tradicional e, ainda, sem interação entre instituição, professorltutor e aluno. (SANTOS, 2008). Infelizmente, ainda hoje, existem instituições que realizam EaD dessa forma maciça e ultrapassada, causando má impressão ao aluno, que acaba transportando esse conceito para todos os locais com EaD, levando à evasão dos cursos.

Com a chegada do rádio, televisão e vídeo, no início da década de 70, a segunda geração ficou conhecida pela junção do uso de meios de comunicação multimídia aos materiais impressos. Apesar de novas formas de disseminação da EaD, o processo de ensino-aprendizagem ainda continuava sendo fadado ao fracasso, pois a forma de utilizar esses mecanismos era individualista, sendo o processo de comunicação unidirecional, reforçando a autoinstrução, ainda que alguns materiais viessem acompanhados de fitas cassetes e/ou apresentação de vídeo. (SANTOS, 2008)

Por maior que fosse o esforço do aluno para se comunicar com o professor por outros meios, a tentativa era inútil, não havia diálogo, muito menos interação entre ambos, o que foi e é um dos geradores de grandes problemas que a EaD tem tentado solucionar até nossos dias: a falta de interação. Outro viés para a $\mathrm{EaD}$ foi a reprodução em série dos conteúdos, desconsiderando as necessidades individuais e a experiência adquirida pelo aluno anteriormente, não se encaixando com a realidade cotidiana. (SANTOS, 2008)

A terceira geração, EaD informatizada, começou a partir da década de 90 e tem assumido a educação como um processo de comunicação, tendo como base a comunicação multidirecional e sincrônica (real time) facilitada pelo avanço das NTICs, representadas por um modelo de aprendizagem por conferência. Houve ganho com a possibilidade de atividades síncronas, porém se perdeu uma das maiores vantagens que se adquiriu com a EaD: a flexibilidade de tempo, sem horário marcado, e de espaço, sem local definido para as conferências. Esse novo modelo foi adotado principalmente pelas Instituições de Ensino Superior - IES, inicialmente, nos Estados Unidos. (SANTOS, 2008) 
Já a quarta geração foi marcada pela flexibilização do processo de aprendizagem, juntando todas as características e vantagens da geração anterior, o que possibilitou que o processo de ensino fosse realizado por meio de uma aprendizagem não linear, interativa e, principalmente, colaborativa, baseada na WEB 2.0, segunda geração de comunidades e serviços oferecidos na internet. Essa nova forma incentivou a formação do autodidata, que tem livre exploração sobre o assunto e livre escolha de busca contínua de informações complementares, sempre melhorando o seu conhecimento. (SANTOS, 2008). A interatividade, que foi considerada um viés nas gerações anteriores, tornou-se imprescindível e importante instrumento no processo de ensino-aprendizagem. Por exemplo, as videoconferências são recursos que objetivam diminuir a sensação de distanciamento físico. (SANTOS, 2008)

Após a divulgação desses recursos disponíveis, surgiram os AVAs (Ambientes Virtuais de Aprendizagem), que são simuladores de uma aula em sala presencial e, assim, torna-se a ganhar a flexibilidade de tempo e local que se havia perdido, sem se esquecer da interatividade pessoal como chave principal para a aprendizagem efetiva. Essa flexibilidade foi possível devido à criação de uma rede de apoio ao estudante, quando não é possível a comunicação em tempo real com tutores/professores ou monitores. A comunicação pode ser feita por meios eletrônicos dos próprios AVAs ou por outros mecanismos com mensagem instantânea: Gmail, MSN, Skype, YaHoo entre outros. (SANTOS, 2008)

Atualmente, nos encontramos na quinta geração da $\mathrm{EaD}$, em que o uso de NTICs continua acelerado e distribuído entre toda a população, com a diminuição dos vieses das gerações anteriores. A EaD mantém a ânsia de continuar crescendo com propósito de diminuir os custos locais e os professores em sala e afetar positivamente a educação, levando melhorias à capacitação em escala global. (SANTOS, 2008)

Segundo seus idealizadores e especialistas, um viés presente na quinta geração é a sobrecarga que os professores sofrem devido às solicitações intermináveis e, muitas vezes, desnecessárias dos alunos por feedback. Mas já se tem uma solução: a criação de uma base de dados inteligentes que armazenem e classifiquem de forma estruturada todo o conteúdo e todo o material relacionado à 
matéria que o aluno poderá precisar para consultas futuras. Isso se tornou uma rica fonte de consulta para os cursos nesse modelo de aprendizagem, levando à diminuição da necessidade extrema e urgente do professorltutor. (SANTOS, 2008)

Estamos tendo, sem dúvida, nessa nova geração a possibilidade de refletir, analisar possibilidades e nos defrontarmos com inúmeras oportunidades jamais pensadas nas outras gerações de educação, procurando e instalando novas formas de EaD, sanando os dificultadores.

A EaD tem sido colocada como uma forma dinâmica, crucial com base legal para ampliação das oportunidades educacionais. Essa nova modalidade de educação tem democratizado o acesso à educação superior e às especializações, apontando os recursos tecnológicos como mediadores mais eficazes no processo de formação humana, propondo novas possibilidades de uma educação ampla e de qualidade sem discriminação. (CENSO, 2011).

Registros históricos colocam que o Brasil estava entres os principais no mundo no desenvolvimento de EaD especialmente até os anos 70. A partir dessa época, o Brasil estagnou por falta de recurso, voltando à ativa somente no final do milênio, gerando nova fase de prosperidade e desenvolvimento por meio da chegada de novas maneiras de disseminar a educação, NTCls. (MATTEI, REJANE, 2012)

A modalidade Educação à Distância tem se difundido por todo o território brasileiro, minimizando os diversos problemas relacionados à educação, em qualquer estágio, levando conhecimento às regiões mais inóspitas sem educação presencial. (SILVEIRA, 2015). A evolução e o avanço tecnológicos com suas consequências estão determinando uma nova ordem econômica e social nos mais variados campos da vida humana e isso não poderia deixar de acontecer na área de educação, justamente porque é conhecido que a educação é a forma de moldar mentes, levando todos a uma evolução de conhecimento. (NUNES, 1992)

Nos dias de hoje, a EaD é vista como um produto de primeira linha, ganhou interatividade, estimulação multimídia, e tudo isso com baixo custo, o que vem estimulando o aluno a cursar $\mathrm{EaD}$ e as instituições a oferecer os cursos, sem contar que o percentual de evasão é menor do que no ensino regular presencial. Com o passar dos anos, a EaD evoluiu consideravelmente, sendo caracterizada e reconhecida de acordo com os recursos tecnológicos utilizados. Por isso, a cada 
semestre, há um aumento na aceitação da população e grande procura por esse tipo de ensino. A Associação Brasileira de Educação à Distância (ABED, 2009) afirma que, em 2007, mais de 2 milhões de brasileiros cursaram alguma matéria em diferentes áreas de conhecimento em EaD.

No que diz respeito à fase atual da $\mathrm{EaD}$, faz-se necessário dizer que nada disso seria possível se não fossem as últimas transformações e evoluções impulsionadas pelas NTICs, que foram extremamente impactantes nas transformações sociais mundiais. Sem isso, não teria acontecido esse boom na EaD, e provavelmente ainda estaríamos utilizando cartas para a nossa comunicação e disseminação da educação. (BRUNNER, 2004).

Em menos de duas décadas, a tecnologia evolui, levando o mundo a grandes mudanças em todas as áreas. A economia mundial, acúmulo do capital, avançou por todo o planeta, tornando-se a economia global, tudo isso devido à nova infraestrutura proporcionada pelas NTICs. (BRUNNER, 2004). Aconteceram ainda transformações grandiosas nas bases filosóficas que regem o sistema social e educacional, sendo significativas nas formas do "saber fazer" e do "fazer saber", entre o fazer e o compreender, levando a uma nova forma de informar e educar, entrando em uma nova fase do conhecimento, diminuindo assim o distanciamento entre a teoria e a prática. (UNESP, 2005)

Isso causou mudanças até culturais, levando a recente geração a uma nova forma de viver, de estudar e de ser. Todos estão sempre "linkados" uns aos outros por meio de mensagens, audiovisuais, e-mail, ou através de redes sociais, que se formam por meio da comunicação mediada por computadores (CMC). Essas mudanças também resultaram em nova forma de fazer amizade, namorar e até casar, criando comunidades com ideias em comuns, compartilhando virtualmente dos mesmos objetivos e interesses. A vantagem de tudo isso é adquirir novos conhecimentos virtuais e simultâneos do saber sem nenhuma exigência de local e hora, conhecimentos que surgem a todo o momento, devido a essa conectividade ininterrupta. Isso leva à percepção clara de que todo o processo de ensinoaprendizagem ganhou novas formas e escalas, sustentadas e impulsionadas pelas explosivas NTICs. (WAQUIL, 2009) 
É nesse contexto atual da nova, integrada e consolidada sociedade da informação e do conhecimento que a Educação à Distância assume seu papel e apropria-se de novas formas e regras nascidas juntas com as NTICs. (RIBEIRO ET ALL, 2008)

A educação como um todo sofreu grandes modificações a partir da LDB № 9.394/96, e, em especial, a EaD foi tratada como uma forma de ensino equivalente ao presencial. Na LDB anterior, a EaD era tratada como um ensino de segunda linha. A EaD ganhou status de ensino regular após a promulgação da LBD $n^{\circ}$ 9.394/96, que se posicionou a favor desse tipo de ensino. Percebeu-se o grande potencial em suas mãos e um forte aliado no atendimento das necessidades constantes de atualização e continuação dos estudos para todos os profissionais de diferentes áreas. (SOFFNER, 2010)

A aprovação da Lei de Diretrizes e Bases n 9.394/96 apresenta-se como uma das principais ações rumo à implementação da EaD em nível superior no País, já que foi a primeira lei nacional a tratar da questão. (SANTOS, 2008). Após a sua aprovação, houve um processo de expansão da educação superior, no processo de reforma do estado e do sistema educativo no Brasil com a bandeira de diversificação e diferenciação das IFES, isso sendo da forma mais dinâmica, levando à ampliação das oportunidades educacionais. Esse discurso ganha força dando um boom expansionista na Educação à Distância (EaD). (SANTOS, 2008)

O Decreto $\mathrm{n}^{\circ}$. 2.494/98, que regulamenta o artigo 80 da LDB, é o que define a Educação à Distância como uma forma de ensino que possibilita a autoaprendizagem, através de recursos didáticos organizados pelos diversos meios de comunicação. A Portaria №. 4.059/04 deu às Instituições de Ensino Superior IES a responsabilidade de utilizar a disseminação do conhecimento através da EaD e, com isso, a procura por cursos à distância no Brasil e o número de alunos aumentaram consideravelmente, o que foi afirmado pela ABED - Associação Brasileira de Educação à Distância - ABED). (DUARTE, 2011)

A EaD tem ganhado espaço em todos níveis de ensino. Grande parte desse espaço se deve aos incentivos governamentais e às NTICs, e isso vem ocorrendo com o propósito eminente de que, por meio dessa modalidade, o problema de democratização de estudo seja resolvido, levando o acesso à educação de forma 
mais rápida e ágil a toda a população independentemente de sua localidade. (MEC, UNESCO, 2007)

Essas leis impulsionaram o crescimento da EaD, alcançando todos, principalmente os que residem na periferia das grandes cidades. Esses conhecem as dificuldades enfrentadas devido a necessitarem de transporte público levando muito tempo para se locomover de um ponto a outro, impossibilitando-os de realizar um curso presencial. Esse tempo gasto com deslocamento seria muito mais bem aproveitado se o indivíduo estivesse participando do seu local de trabalho ou da sua própria residência de cursos à distância. Essa flexibilidade traz a vantagem e possibilidade de o aluno participar de cursos em qualquer lugar do mundo, até mesmo durante uma viagem, seja a negócios ou lazer.

O conceito de $\mathrm{EaD}$ é regido pelo Decreto 5.622/2005, que define a $\mathrm{EaD}$ como modalidade educativa em que a passagem de informação como forma de transmissão de ensino leva à aprendizagem e se dá por meio da utilização de meios e tecnologias de informação e comunicação, com estudantes e professores/tutores desenvolvendo atividades em lugares e/ou tempo diversos.

Essa nova concepção de estudo atende perfeitamente às exigências $e$ necessidades do mercado de trabalho numa perspectiva globalizada e privilegia a interação entre diferentes culturas, tendo como objetivo comum a produção do conhecimento para a formação humana numa perspectiva ampla, suprindo suas necessidades nos dias atuais. O cenário principal da expansão da educação superior por meio da EaD aconteceu durante as três últimas décadas do século $\mathrm{XX}$, especialmente no ano de 1990 devido a chegada da internet ao Brasil. (SOFFNER, 2010)

\subsection{PROCESSO ENSINO-APRENDIZAGEM}

O processo ensino-aprendizagem é definido por Kubo e Botomé, 2001, como um nome para um complexo sistema de interação comportamental entre professores e alunos. Para Paulo Freire, 1996, não existe ensino sem aprendizagem, pois, para ele, educar alguém é um processo em que ocorre acontece intercâmbio constante. 
Esse processo pode ser caracterizado de inúmeras formas diferentes, às vezes colocando o professor em foco ou o aluno. Contudo, independentemente da forma, sempre deve promover um diálogo interligado entre o conteúdo proposto, curricular, e os conteúdos únicos como vivências, histórias, individualidade de ambos os participantes, ganhando como produto final a formação integral da personalidade do aluno através das contribuições. (KUBO e BOTOMÉ, 2001)

O aluno precisa se formar capaz e inteligente, para que, diante de uma situação problemática, ele seja capaz de enfrentar, buscar soluções e resolver as situações. O processo ensino-aprendizagem deve desenvolver a formação de valores, sentimentos que identificam o homem como ser social, que por fim leva à formação plena da personalidade do indivíduo. A confirmação de ter alcançado êxito irá aparecer na resposta que esse indivíduo dará ao surgimento de um problema, lançando mão de todo o conhecimento, sentimentos, desenvolvimento intelectual e físico, juntamente com qualidades e valores, que o levaram a promover ações coletivas através da solidariedade e saber viver em comunidade.

\subsubsection{Processo Ensino-Aprendizagem na EAD}

O processo de ensino-aprendizagem no sistema educacional tradicional pode ser modelizado através do triângulo pedagógico "professor-aluno-conteúdo". Na EaD não podia ser diferente, uma vez que o processo não é só importante e sim essencial. $\mathrm{Na} \mathrm{EaD} \mathrm{o} \mathrm{professor} \mathrm{assume} \mathrm{o} \mathrm{papel} \mathrm{de} \mathrm{mediador,} \mathrm{apresenta} \mathrm{o} \mathrm{conteúdo}$ que será aprendido pelo aluno, e o uso das NTCls se encontra como um acréscimo de elemento no triângulo pedagógico, "professor-aluno-conteúdo-NTCls", transformando o triângulo em um tetraedro, que logicamente deve apresentar novas relações entre os elementos envolvidos. (BRAGA, 2012). Então, as NTCls são as mediadores através de seus grandes recursos, mas ainda existe a necessidade de um estudo aprofundado sobre as influências, vantagens e dificuldades, considerando esse novo tipo de mediador, para que leve a uma aprendizagem eficiente. (BRAGA, 2012) 
A autonomia é extremamente exigida do aluno dentro de sua formação através de um Ambiente Virtual desde o início do processo até o final. Caso contrário, uma divisão errada do tempo ou uma má percepção do ambiente podem atrapalhar a aprendizagem ou até mesmo levar ao abandono da formação. (LINARD, 1995). A passagem do conteúdo por meio do suporte virtual tem grande importância, podendo ser de forma passiva, interativa ou participativa, o que poderá levar a uma influência positiva ou negativa. (www.ufvjm.br/vozes)

Assim, a inserção das NTCls e o seu uso na educação conduz à disseminação do conhecimento, havendo interação importante entre professor, aluno e conteúdo. A interação aluno-computador deve sempre ser de forma fácil, eficiente, estimulante, intuitiva e centrada, levando o aluno a um sentimento de satisfação sobre o seu conhecimento adquirido, gerando aprendizagem.

O uso do computador no ensino tem evoluído. Primeiramente, foi chamado pelo termo "Ambiente Assistido pelo Computador", mudado para o termo "Ambiente Inteligente Assistido pelo Computador" (TCHOUNIKINE, 2002), depois para "Ambiente Interativo de Aprendizagem com o Computador" (BRUILLARD, 1997), para enfim ser concebido como "Ambiente Virtual de Aprendizagem" (AVA). Com este último termo, o foco passa do suporte virtual para a aprendizagem humana. Os AVAs modificam o sistema de relações sociais, em que o dispositivo é o meio de ação e não apenas o intermediário entre o sujeito e o objeto de aprendizagem (LINARD, 1995).

Nos Ambientes Virtuais de Aprendizagem, o aluno deve e precisa ser autônomo, consciente e responsável pelos seus atos, motivando-se a si mesmo e se conhecendo em relação às suas dificuldades com o conteúdo e assim tentar resolvêlas. Levy (1999) define essa cultura com o conceito de Cibercultura: "conjunto de técnicas (materiais e intelectuais), de práticas, de atitudes, de modos de pensamento e de valores que se desenvolvem juntamente com o crescimento do ciberespaço." (LEVY, 1999)

Conclui-se que o uso de AVA é um mediador significativo, assumindo a responsabilidade de disseminar o conteúdo programado com o professor responsável por todo essa configuração como interface interativa. O AVA tem um suporte presente com público alvo correto, com conteúdo interativo e estimulante. A 
forma de apresentação da matéria é decisiva na diminuição da evasão da EaD, pois é ela que leva o aluno a continuar estudando e adquirindo uma boa aprendizagem.

\subsection{AMBIENTE VIRTUAL DE APRENDIZAGEM - AVA}

O Ambiente Virtual de Aprendizagem é um software WEB cujo ambiente possibilita gerenciar conteúdos e administrar cursos virtuais integrando diversas ferramentas (síncronas e assíncronas) devidamente organizadas. Por meio dessas ferramentas é possível disponibilizar conteúdos, criar debates, promover chats, enviar mensagens e acompanhar constantemente o desenvolvimento cognitivo do aluno. Tem como intencionalidade auxiliar o professor em suas funções e dar suporte ao processo de ensino-aprendizagem do aluno. As interações realizadas entre professor, tutor/aluno e aluno/aluno podem variar dependendo do tipo de curso escolhido pela Instituição de Ensino Superior. (MATTAR, 2014)

AVA é o "local virtual" em que, em geral, os cursos na modalidade à distância ou semipresencial acontecem. São ambientes que utilizam plataformas especialmente planejadas para abrigar cursos. Tem origem do inglês "Virtual learning environment" e são softwaresque auxiliam na montagem de cursos acessíveis pela internet. Foi elaborado para ajudar os professores no gerenciamento de conteúdo para seus alunos e na administração do curso. (MATTAR, 2014)

Recentemente, as IES que ofertavam cursos de EaD on-line não utilizavam as AVAs, também conhecidos no Brasil como SGC - Sistema Gerenciador de Curso ou Plataforma Virtual, e-learning. Utilizavam apenas as páginas da internet (sítios eletrônicos) para divulgar informações estáticas da instituição, do curso, da prescrição curricular e disponibilizar conteúdo técnico das disciplinas. (FUJITA, 2010) 
A Criação de Comunidades Virtuais, um tipo de AVA, é um dos princípios que orientam o crescimento inicial do ciberespaço, ao lado da Interconexão e da Inteligência Coletiva. A Comunidade Virtual é um princípio essencial, segundo Lévy, mas necessita ir além de simples Agregação Eletrônica de pessoas para se tornar uma Comunidade Virtual de Aprendizagem. (LEVY, 1999). Isso justificaria a criação de Comunidade Virtual como sendo essencial para o estabelecimento de uma cultura de EaD. Porém, percebe-se que a simples criação de comunidades virtuais não significa a criação de grupos de estudo pela internet, pois aquelas possuem os mais diversos interesses, que vão desde o entretenimento até a distribuição de notícias. Então a comunidade virtual voltada para a educação deve ser criada somente com o foco de divulgar conhecimento.(LEVY, 1999)

Cabe ressaltar que o perfil cognitivo dos alunos que frequentam AVAs é distinto do perfil daqueles que frequentam espaços presenciais. Normalmente se trata de um aluno leitor imersivo (da internet), que por sua vez poderia ser classificado em três níveis: internauta errante, detetive e previdente. (ROSADO, 2015)

O internauta errante é um aluno que explora os ambientes digitais sem ter noção de muita coisa, suas pesquisas são feitas de forma aleatória com várias possibilidades, sem ter o medo de errar. Já o internauta detetive tem uma noção melhor, com responsabilidade de seus atos, sempre aprendendo com suas experiências. E, finalmente, o internauta previdente é aquele aluno que já fez algum curso para aprender a navegar, se sente familiarizado e os erros ocorrem em menor frequência. (SANTAELLA, 2004; apud ROSADO, 2015)

Uma tendência, não apenas no Brasil, tem sido a utilização de AVAs gratuitos, de códigos abertos e/ou livres, já utilizados pela maioria das instituições de ensino em nosso País, com crescente proporção de utilização no caso das instituições públicas. Entre os AVAs gratuitos, o Moodle tornou-se uma escolha bastante comum nos últimos anos. No Brasil, seu uso tem sido ainda reforçado pelo fato de a Universidade Aberta do Brasil (UAB) adotá-lo.(MAIA, 2003)

No caso do Curso de Tópicos Avançados em Promoção da Saúde - TAPS em Ciências da saúde, a plataforma utilizada é o Moodle. Nela existem áreas para apresentação de conteúdos em vídeo, animações, textos, atividades de verificação 
da aprendizagem - não avaliativas e avaliativas. Também estão disponíveis espaços para interação síncrona, por meio de chats, e interação assíncrona, através dos fóruns de discussão. Esses recursos permitem a interação dos estudantes entre si e com a equipe de professores, tutores e monitores.

A organização do Ambiente Virtual permite ao aluno um acompanhamento organizado e sistematizado daquilo que é estudado a cada semana. A recuperação da informação e dos conteúdos estudados também é um dos benefícios proporcionados por cursos à distância que utilizam AVA.

Apesar dos benefícios, também existem os seus malefícios relacionados com a rede social, pois, enquanto as universidades, em geral, lutam para ampliar a adoção de seus Ambientes Virtuais de Aprendizagem, motivadas principalmente pelo uso de novas tecnologias, enfrentam o problema oposto com as redes sociais, pois não conseguem fazer com que os alunos parem de usá-las durante as aulas, o que afeta todo tipo de educação, presencial ou à distância, o que pode ser objeto de estudo no futuro.

\subsubsection{MOODLE}

O Moodle é o acrônimo de "Modular Object-Oriented Dynamic Learning Environment", um software livre, de apoio à aprendizagem, executado em um Ambiente Virtual (ver Ambiente Virtual de Aprendizagem). Ainda, um CMS (Course Management System), também definido como um LMS (Learning Management System) ou VLE (Virtual Learning Environment), é uma plataforma de apoio à aprendizagem à distância em um trabalho colaborativo, baseado nesse software ou plataforma acessível através da internet. Com ele é possível programar estratégias de treinamento à distância com total acompanhamento dos participantes, criar cursos, disponibilizar leituras complementares, criar mecanismos modernos de comunicação síncrona e assíncrona e fazer com que alunos criem e disseminem conhecimentos através de Wiki, glossários, fóruns e bases de dados, entre outras 
funções. Em inglês o verbo "to moodle" significa navegar procurando por algo, enquanto faz várias coisas ao mesmo tempo. (MATTAR, 2014)

Definiremos dentro do Moodle alguns componentes que se encaixam na matéria Tópicos Avançados em Promoção da Saúde - TAPS.

Fórum - é uma atividade do Moodle que permite diálogos assíncronos do grupo sobre um determinado tema. A participação em fóruns pode ser uma parte integral da compreensão de um tema. Além dos professores/ tutores, os alunos podem também avaliar as postagens uns dos outros. Há diversos modelos de fóruns, como o fórum em que o aluno só poderá visualizar as postagens dos colegas após fazer a sua postagem. (MATTAR, 2014)

Lição - consiste em um número de páginas ou slides que podem ter questões intercaladas com classificação e em que o prosseguimento do aluno depende das suas respostas. De acordo com a resposta do aluno, ele pode progredir na lição ou voltar atrás. Dessa forma, "guiamos" o aluno de acordo com o seu desempenho e no final existe uma qualificação. (MATTAR, 2014)

Base de dados - é um compartilhamento de informação de forma organizada e indexada (áudio, vídeo, imagem, apresentação, docs, planilhas etc.). Os próprios alunos podem inserir novos itens na base de dados e comentar os itens já postados pelos colegas. Exemplo: criar uma bibliografia comentada em que cada aluno possa postar e comentar vários itens, anexar arquivos e incluir vídeos. (MATTAR, 2014)

Recursos - servem para incluir conteúdos em um curso. Podem ser textos simples, textos com hiperlinks, arquivos multimídia, diretórios, links. O Moodle possui integração com vários repositórios externos: googledocs, dropbox, picasa e flickr, entre outros. (MATTAR, 2014)

Grupos e agrupamentos - está opção permite que uma turma de alunos seja dividida em pequenos ou grandes grupos, e a partir dos grupos é possível formar os agrupamentos (subgrupos de grupos já formados). Ao criar uma atividade/ recurso, o professor poderá, por exemplo, atribuí-la exclusivamente a um determinado agrupamento. (MATTAR, 2014)

Com o desenvolvimento da Web 2.0, novas plataformas passaram a ser utilizadas como Ambientes Virtuais de Aprendizagem, com características gerais 
mais flexíveis que os AVAs tradicionais. Entre essas plataformas, podem ser mencionados Youtube, Twitter e Facebook. (BUSARELLO, 2013).

A redefinição de uma comunidade virtual orientada especificamente para 'aprendizagem' é difícil. Na verdade, as múltiplas e incessantes trocas que ocorrem em qualquer tipo de comunidade virtual refletem-se em inúmeras e diferenciadas aprendizagens para seus membros [...] Três possibilidades, no entanto, são importantes nas comunidades que possuem fins educativos: a interação, a cooperação e a colaboração on-line. (Tecnologias e Ensino Presencial e a Distância - Kenski, 2006)

Para atingir seus objetivos educacionais, os AVAs necessitam de princípios de comportamento que favoreçam a aprendizagem, como a construção coletiva, a existência de interesse mútuo e regras de resolução de conflitos, permitindo que a simples agregação eletrônica de pessoas se torne uma Comunidade Virtual de Aprendizagem. Para facilitar a criação dessas comunidades, de aprendizagem ou não, surgiram na internet diversos softwares de agregação de pessoas. Entre os muitos, alguns são voltados ao entretenimento, outros à distribuição de notícias até que chegar naqueles focados no sistema de ensino e aprendizagem pela internet. Esses softwares trazem consigo discussões pedagógicas para o desenvolvimento de metodologias educacionais utilizando canais de interação web. Assim, softwares como TelEduc, Moodle, Solar, Sócrates, entre outros, ganham espaço no cotidiano dos educadores virtuais pelo fato de possibilitarem fácil manuseio e controle de aulas, discussões, apresentações, enfim, atividades educacionais de forma virtual. (MOZZER, 2004)

Ambientes digitais de aprendizagem são sistemas computacionais disponíveis na internet, destinados ao suporte de atividades mediadas pelas tecnologias de informação e comunicação. Permitem integrar múltiplas mídias, linguagens e recursos, apresentar informações de maneira organizada, desenvolver interações entre pessoas e objetos de conhecimento, elaborar e socializar produções tendo em vista atingir determinados objetivos. (Educação à distância na internet - Maria Elizabeth Bianconcini de Almeida, 2003)

Com os chamados Ambientes Virtuais de Aprendizagem, a EaD ganhou a possibilidade de organizar cursos de maneira mais controlada, podendo mesclar 
aulas presenciais e à distância. Ganhou ainda a possibilidade de aulas apenas virtuais com integração das novas possibilidades por meio da internet, juntamente com a aproximação entre professores e alunos dentro do processo educativo. $O$ número de ferramentas disponíveis nos AVAs tem crescido a cada dia. São eles: emails, fóruns, conferências, bate-papos, arquivos de textos, wikis, blogs, entre outros. Ressalta-se que, em todos esses ambientes, textos, imagens e vídeos podem circular de maneira a integrar mídias e potencializar o poder de educação através da comunicação. Além disso, a possibilidade de hiperlinks traz o aumento do raio de conhecimento possível de ser desenvolvido pelos alunos. Esses hiperlinks podem ser realizados tanto dentro do próprio ambiente digital de aprendizagem (entre textos indicados ou entre discussões em fóruns diferentes, por exemplo), como também de dentro para fora e de fora para dentro (em casos de pesquisas alargadas de discussões internas, nos quais se pode trazer ou levar conteúdo desenvolvido para a discussão). (RIBEIRO, 2007)

De acordo com a Profa. Dra. Maria Elizabeth Bianconcini de Almeida, 2003, existem três nomenclaturas conhecidas para o modelo de educação à distância: Educação On-line, Educação à Distância e E-Learning.

1- Educação à Distância: realiza-se por diferentes meios (correspondência postal ou eletrônica, rádio, televisão, telefone, fax, computador, internet, entre outros). É um termo abrangente e mantém a relação de discussão de tempo e espaço (distanciamento físico) dentro do processo educacional, porém não é obrigatoriamente dentro do ambiente internet.

2- Educação On-line: realizada obrigatoriamente por meio da internet, esta como meio principal. Pode ser utilizada de forma síncrona ou assíncrona. Tem como características mais enfáticas a velocidade na troca de informações, o feedback entre alunos e professores e o grau de interatividade alcançado.

3- E-Learning: formato de educação à distância com suporte na internet. É muito utilizado por empresas em processos de treinamento de funcionários e seleção de pessoal. Seu foco consiste em organizar e disponibilizar materiais didáticos.

Assim, percebe-se que o modelo de Educação à Distância, dentro do conceito de Educação On-Line, se apresenta como o mais interativo, pois requer das 
ferramentas o uso de forma ideal, despertando a autonomia e construção coletiva do conhecimento, o que reitera a importância dos Ambientes Virtuais de Aprendizagem (AVAs). A utilização dessas ferramentas trouxe à Educação à Distância não só a potencialização dos conceitos de autonomia e construção coletiva, mas também a permanência dos alunos nos cursos. Isso porque, através dessas ferramentas, há a possibilidade da participação ativa de alunos e professores e o incentivo à responsabilidade deles para com o aprendizado.

Dessa forma, entende-se que não há restrições quanto ao uso de determinadas ferramentas de internet por educadores, mas sim a necessidade de que esse conjunto de comportamentos e regras de convivência esteja presente em qualquer atividade educacional via internet, independentemente das ferramentas utilizadas. (MATTAR, 2014)

Nos "AVAs", essa união de cidadãos conectados, agrupados virtualmente em torno de interesses específicos, pode construir uma comunidade a partir do momento em que se estabelecem regras, valores, limites, usos e costumes, a etiqueta, com as restrições e os sentimentos de acolhimento e 'pertencimento' ao grupo." (Tecnologias e Ensino Presencial e a Distância-Kenski, 2006)

\subsubsection{NESPROM (Núcleo de Estudos em Educação e Promoção à Saúde)}

O grupo Nesprom começou suas atividades como um grupo de estudos em 1989, dentro do Departamento de Enfermagem, com atividades extensionistas e de ensino. Nessa época, a atuação era limitada ao ensino de graduação, com algumas participações voluntárias em cursos de pós-graduação em saúde e em desenvolvimento de atividades de extensão e pesquisas. (NESPROM, 2014)

O NESPROM passou a ser reconhecido, como grupo, a partir de 1993, por ocasião do primeiro financiamento pelo Conselho Nacional de Desenvolvimento Científico e Tecnológico - CNPq, embora já tivesse o seu embrião fecundado desde 
1989, através dos primeiros projetos extensionistas de seu coordenador e colaboradores. (NESPROM, 2014)

No período de 1990 a 1993, os estudos voltados à promoção da saúdenutrição vieram fortalecer as tendências e perspectivas da consolidação do grupo, que contribuiu com a comunidade do Paranoá - DF na capacitação/ formação das primeiras turmas de vigilantes de saúde para promoção da saúde. (NESPROM, 2014)

A criação desse grupo foi resultado das experiências adquiridas em três momentos. Primeiramente, o Movimentar Institucional, de 1989 a 1992, que se identifica pela participação em vários projetos e atividades como grupo, caracterizado pelo interesse individual de seus integrantes por um maior compromisso com a Universidade. (NESPROM, 2014)

O Movimentar Organizado, de 1992 a 1993, o segundo momento, se caracterizou pela definição e participação em um primeiro projeto integrado de pesquisa financiado pelo CNPq e, dentro do enfoque da promoção da saúde, juntou vários profissionais. E o terceiro momento foi o Movimentar Interdisciplinar, de 1993 aos dias atuais, que se caracterizou pela participação da equipe de trabalho em projetos interdisciplinares e interinstitucionais, buscando alcançar dois objetivos: primeiro, o da produção científica como grupo; segundo, o da qualificação técnicocientífica dos participantes do grupo. (NESPROM, 2014)

Os relatórios, projetos e documentos produzidos no Departamento de Enfermagem da Universidade de Brasília - UnB, no período de 1990 a 1997, demonstram uma variedade de interesses e buscas em diferentes áreas do conhecimento, predominantemente voltados à melhoria da qualidade de assistência prestada ao cliente e de novas metodologias para o ensino na graduação. Então esse período foi marcada por uma ideia inovadora dentro das linhas de pesquisas do NESPROM, "Determinantes do Processo Saúde-Doença" e "Educação, Cidadania e Sociedade", resultando em implicações e modificações no ensino, na pesquisa e na extensão, não só da enfermagem, mas de outros cursos da área de saúde e educação da Universidade de Brasília. (NESPROM, 2014)

A partir do ano 2000, o grupo criou uma plataforma, Nesprom (Figura 1), para divulgar todas as informações adquiridas e promover os cursos na área da saúde. A disciplina TAPS se encontra hospedada nessa plataforma. 


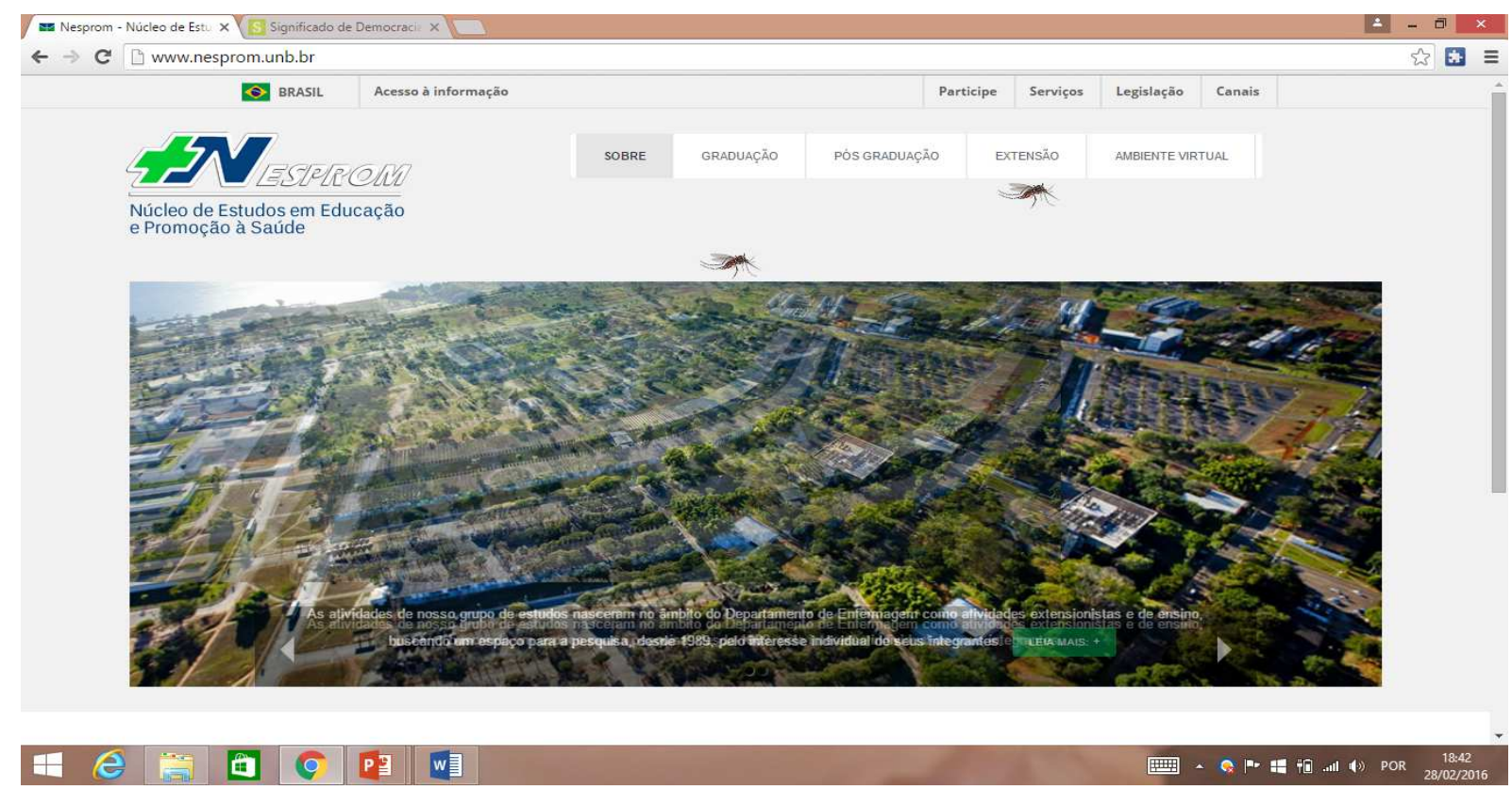

Figura 1 - Interface do NESPROM.

\subsection{SAÚDE NO BRASIL}

O cuidado ao longo da história da humanidade tem sua prática relacionada à cultura e à necessidade de sobrevivência da espécie, muito relacionada ao modo de ser e viver dos seres humanos. (ALVES, 2014). Com a evolução da humanidade nas diversas fases históricas, o cuidado surgiu de modo instintivo, como quando a mãe cuida de seu pequeno bebê indefeso, acompanhado pela necessidade de proteção, como a de se alojar em abrigos contra as alterações climáticas. Contudo, viver em sociedade passou a ser também, ao longo da história, uma prática de cuidado coletivo, que, dependendo do modelo político e econômico em vigência, gera um impacto na vida da população e nas relações interpessoais, o que pode provocar uma satisfação ou insatisfação em relação à qualidade de vida dos sujeitos, suas famílias e comunidades em que vivem. (ALVES, 2014)

A equipe multidisciplinar é um campo de conhecimento em que se formam teorias que orientam as práticas de cuidado durante o processo de cuidado, seja ele 
individual, de acordo com a especialidade, ou de modo coletivo entre a equipe. Este colabora, assim, com o processo saúde - doença - cuidado dos sujeitos, numa perspectiva da atenção (primária, secundária terciária e quartenária) com vistas a uma assistência humanizada, equânime, efetiva e eficiente. (ALVES, 2014)

O cotidiano do trabalho dos profissionais de saúde os leva a conviverem com sentimentos e formas extremas de dor e sofrimento, muitas vezes lhes causando um desgaste físico, psicoemocional e espiritual, que refletem em sua qualidade de vida, de trabalho e de saúde. Esses profissionais, embora tragam o desejo de boas ações e melhorias na saúde, muitas vezes se esquecem de promoverem o seu próprio aprendizado. (ALVES, 2014). A sobrecarga e as condições precárias de trabalho somadas aos dilemas e conflitos cotidianos desse trabalho e a consequente insatisfação profissional acabam por afetar o seu bem-estar, gerando problemas de produção de saúde para o trabalhador. Esse cenário leva, muitas vezes, a um desgaste interno, que reflete na qualidade de vida e de trabalho. (ALVES,2014). As escalas ininterruptas e jornadas exaustivas de plantões, a sobrecarrega de ações, as condições precárias do trabalho, aliadas aos dilemas e conflitos do trabalho na saúde acabam por afetar a subjetividade de cada trabalhador. Com isso, há uma necessidade de o profissional de saúde começar a se harmonizar com a busca por conhecimento atualizado antes de tornar-se um veículo de cuidado e de cura de outro. (ALVES, 2014)

As relações que se estabelecem no mundo tumultuado do trabalho no cotidiano desses profissionais tem privilegiado pouco a qualidade de vida e a valorização do trabalhador, considerando que o grande foco está centrado na imposição da produção em larga escala, na qualidade dos serviços prestados ao outro, na excessiva exploração da mão de obra e nas baixas remunerações. (ALVES, 2014)

Diante de uma crescente demanda populacional e social do mundo cabe aos profissionais da área da saúde, refletirem sobre as questões relacionadas ao sentido humanitário, e a buscarem novos paradigmas e conhecimento para cuidá-lo. Assim a EaD tem o intuito de oferecer uma nova visão para o profissional da saúde e para a sociedade, conduzindo novas maneiras do saber e do fazer para o mundo moderno, para o pós-moderno e para além deste. (ALVES,2014) 
Costenaro e Lacerda, 2001 citam que "os profissionais de saúde não podem limitar sua atenção ao atendimento daquilo que é visível no corpo, é preciso ser oferecido aos profissionais subsídios para que compreendam aquilo que se apresenta de forma invisível aos olhos."

Assim, o processo de Educação à Distância na área da saúde tem como prioridade melhorar o cuidado através de conhecimento adquirido por toda a equipe multidisciplinar na atenção, na assistência e no ensino, por meio de pesquisas e extensões, alcançando melhorias na gestão e na gerencia de serviços de saúde, assim como no controle social na luta em defesa do Sistema Único de Saúde, de forma a obter uma melhor profissionalização da categoria através da inovação tecnológica do cuidado por EaD. (ALVES, 2014).

Nesse contexto do processo de EaD, visualizam-se oportunidades para intercâmbio do conhecimento construído em vários locais para os profissionais da saúde de todo o mundo. Devem-se estimular iniciativas que venham a beneficiar o cuidador para se conhecer melhor e aprender mais, de forma que estará multiplicando o benefício para um contato mais humano e digno nas relações entre os cuidadores e seres cuidados, o que favorece uma assistência mais acolhedora, digna e humanizada. Existe a necessidade eminente de se alimentar o ensino, a pesquisa e a extensão desses profissionais com a contribuição de estudos a respeito da saúde, permitindo a formação de um novo olhar para a área com a criação de uma diferente perspectiva da saúde-doença, incentivando a formação continuada. (ALVES, 2014).

A EaD já conquistou no Brasil maior credibilidade e confiabilidade em cursos de graduação e pós-graduação, tornando-se uma ferramenta indispensável ao Sistema Único de Saúde - SUS, preconizando a educação permanente como um dos pilares da ação voltada para os trabalhadores. (SANTANA, 2015)

Considerando-se que EaD é uma tendência no mundo contemporâneo, o profissional de saúde, mais que qualquer outro profissional, deve procurar permanentemente atualizar-se. As suas competências técnicas, tecnológicas, sociais e culturais devem sempre aprimorar em respeito aos princípios éticos que regem a sua conduta como um profissional apto ao cuidar, de modo que esteja em condições de prestar os melhores cuidados de saúde à população. (CHRISTANTE, 2003) 
A educação é o elemento principal na construção de uma sociedade fundamentada na informação, no conhecimento e no aprendizado. É uma estratégia da sociedade para facilitar que cada indivíduo alcance seu potencial, estimulando-o a colaborar com outros em ações que visam ao bem comum. Parte considerável do desnível entre indivíduos, organizações, regiões e países deve-se à desigualdade de oportunidades relativas ao desenvolvimento da capacidade de aprender e concretizar algo novo. (SANTANA, 2015). A união das novas tecnologias da informação com a EaD tem um papel importante na formação permanente do profissional de saúde, atendendo às suas necessidades e desenvolvendo projetos significativos para o seu aperfeiçoamento em um processo de ação e reação, tornando-se uma ferramenta importantíssima ao serviço de saúde, em especial ao Sistema Único de Saúde No Brasil. (ABREU, 2010)

A Constituição Federal de 1988 estabelece, nos arts. 196 e 197: Saúde é direito de todos e dever do Estado. Garantindo, mediante medidas políticas sociais e econômicas, a redução do risco de doença e de outros agravos e o acesso universal e igualitário às ações e serviços para sua promoção, proteção e recuperação.

Dito isso, fazem-se indispensáveis estudos aprofundados sobre a qualidade da EaD na área de saúde, pois a atualização do profissional deverá atender às preocupações de falta ou defasagem de conhecimento. (COSTA, SANTOS E BRASIL, 2004)

\subsubsection{Saúde}

A História da Saúde Pública no Brasil enfrentou diversas dificuldades institucionais e administrativas decorrentes do limitado desenvolvimento científico, tecnológico e industrial. Da instalação da colônia até a década de 1930, as ações para a saúde eram desenvolvidas sem organização. A partir daí, iniciou-se uma série de transformações com a criação e extinção de diversos órgãos de prevenção e 
controle de doenças. Em 1991, criou-se a Fundação Nacional de Saúde. (SODER, 2011)

No dia 18 de novembro de 1994, com a promulgação da Lei 8.934 , criou-se uma organização dinâmica dos programas de formação continuada em todo o País, que indicou a disposição dos órgãos do governo em suprir as deficiências de educação na área de saúde. (www.planalto. gov.br)

O Sistema Universidade Aberta do Brasil (BRASIL, 2006), de extensiva abrangência, concretizou essa posição estratégica institucional e a opção pela formação na modalidade à distância, acompanhada por vezes da presencial ou semipresencial. O UAB veio ao encontro de uma necessidade imediata, reafirmada pelos resultados da pesquisa e pela compreensão dos órgãos governamentais, devido ao provimento necessário de professores. (NERY, 2014)

A necessidade de pesquisas sobre os programas de formação continuada se justifica à medida que seus resultados e suas repercussões possibilitam aprimorar as ações de gestão dos sistemas educacionais, melhorando os seus programas para atender às necessidades de formação na área da saúde. Igualmente, não se pode deixar de considerar que as soluções são viabilizadas por meio de investimento na formação continuada, considerada de forma ampla. (NERY, 2014).

A tendência ao uso da Ead na formação continuada dos profissionais da saúde vem seguida do desenvolvimento dos profissionais graduados na utilização do universo digital, que faz uso das potencialidades gerenciais e pedagógicas das tecnologias de informação e comunicação. Sendo assim há urgência em atualizar os conhecimentos dos profissionais, cujo déficit costuma ser maior devido ao veloz progresso da ciência nas áreas de medicina e saúde, da indústria de matérias, de medicamentos, de eletrônicos, etc. As descobertas e invenções são amplamente divulgadas pelos meios de comunicação e assim chegam rapidamente. (NERY, 2014)

Giordan, 2005, ao discorrer sobre o ensino de Ciências nos tempos da internet, afirma que os programas de formação à distância devem ser potencializados pela perspectiva de serem executados à distância com alto grau de interatividade, ou seja, comunicação em múltiplas vias, o que quebra a tradição de formação de recursos humanos sob o paradigma da transmissão-recepção. A 
formação de recursos humanos, em especial os que dominam sofisticadas tecnologias em saúde, nem sempre são necessárias na proporção em que são solicitadas. A inovação tecnológica brasileira não tem se desenvolvido para garantir a suficiência em áreas de dependência do SUS, mas deveria alcançar esse objetivo essencial para a consolidação e maturidade do SUS. (SANTOS, 2015)

Então, buscando-se embasar a necessidade da EaD na área da saúde, citamse alguns artigos da Constituição Federal:

Art. 196. A saúde é direito de todos e dever do Estado, garantido mediante políticas sociais e econômicas que visem à redução do risco de doença e de outros agravos e ao acesso universal e igualitário às ações e serviços para sua promoção, proteção e recuperação.

Art. 197. São de relevância pública as ações e serviços de saúde, cabendo ao Poder Público dispor, nos termos da lei, sobre sua regulamentação, fiscalização e controle, devendo sua execução ser feita diretamente ou através de terceiros e, também, por pessoa física ou jurídica de direito privado.

Art. 198. As ações e serviços públicos de saúde integram uma rede regionalizada e hierarquizada e constituem um sistema único, organizado de acordo com as seguintes diretrizes:

I - descentralização, com direção única em cada esfera de governo;

II - atendimento integral, com prioridade para as atividades preventivas, sem prejuízo dos serviços assistenciais;

III - participação da comunidade.

$\S 1^{\circ} \mathrm{O}$ Sistema Único de Saúde será financiado, nos termos do art. 195, com recurso do orçamento da Seguridade Social da União, dos Estados, do Distrito Federal e dos Municípios, além de outras fontes. (Parágrafo único renumerado para $\S 1^{\circ}$ pela Emenda Constitucional oㅜ 29, de 2000) (...)

Art. 199. A assistência à saúde é livre à iniciativa privada.

$\S 1^{0}$ As instituições privadas poderão participar de forma complementar do sistema único de saúde, segundo diretrizes deste, mediante contrato de direito público ou convênio, tendo preferência as entidades filantrópicas e as sem fins lucrativos. 
$\S 2^{\circ}$ É vedada a destinação de recursos públicos para auxílios ou subvenções às instituições privadas com fins lucrativos.

$\S 3^{\circ}$ É vedada a participação direta ou indireta de empresas ou capitais estrangeiros na assistência à saúde no País, salvo nos casos previstos em lei.

$\S 4^{\circ}$ A lei disporá sobre as condições e os requisitos que facilitem a remoção de órgãos, tecidos e substâncias humanas para fins de transplante, pesquisa e tratamento, bem como a coleta, processamento e transfusão de sangue e seus derivados, sendo vedado todo o tipo de comercialização.

Art. 200. Ao Sistema Único de Saúde compete, além de outras atribuições, nos termos da lei:

I - controlar e fiscalizar procedimentos, produtos e substâncias de interesse para a saúde e participar da produção de medicamentos, equipamentos, imunobiológicos, hemoderivados e outros insumos;

II - executar as ações de vigilância sanitária e epidemiológica, bem como as de saúde do trabalhador;

III - ordenar a formação de recursos humanos na área de saúde;

IV - participar da formulação da política e da execução das ações de saneamento básico;

$\underline{V}$ - incrementar em sua área de atuacão o desenvolvimento científico e tecnológico;

$\mathrm{VI}$ - fiscalizar e inspecionar alimentos, compreendido o controle de seu teor nutricional, bem como bebidas e águas para 0 consumo humano;

VII - participar do controle e fiscalização da produção, transporte, guarda e utilização de substâncias e produtos psicoativos, tóxicos e radioativos;

VIII - colaborar na proteção do meio ambiente, nele compreendido o do trabalho.

A saúde acompanhou os processos históricos mundiais e foi remodelada a cada período. Assim também a saúde coletiva passou por altos e baixos, de acordo com o conceito de doença e o conhecimento científico de cada momento. 
Segundo Gilberto Hochman, Paula Xavier dos Santos e Fernando PiresAlves (2009):

Que a saúde e a enfermidade são algo mais que fenômenos biológicos; de que em torno dos cuidados, dos mecanismos de controle e das curas estão dimensões relevantes da história da saúde e da doença [...] e que o processo saúde-doença é revelador de aspectos cruciais da modernidade e da história social, política, intelectual e cultura".

A Saúde no Brasil tem padecido há alguns anos e encontra-se cada dia mais próxima de uma catástrofe. Tem sofrido o descaso e o desrespeito do governo, pois os profissionais não buscam uma boa qualificação, por falta de estímulos, e por falta de remuneração condizente com o trabalho, levando-os ao desinteresse e abandono dos centros de saúde. As unidades de saúde e os hospitais são precários. Não há infraestrutura básica de atendimento, os vínculos profissionais são deficientes e a gestão é deficitária. Existem relatos de má conduta de profissionais que levam a população a uma descrença quanto à solução das dificuldades da saúde em sua dimensão coletiva, enquanto deveria ser desejo de todos ter um SUS eficiente, humano e qualitativo, e não um quebra galho. (SANTOS, 2015)

O Jornal Data Folha relatou que $45 \%$ dos brasileiros identificam a saúde como o principal problema do País. É considerada ruim ou péssima por $62 \%$ da população. A insatisfação é maior nas cidades com mais de 500 mil habitantes. (Interfarma - Associação da Indústria Farmacêutica de Pesquisa, 2012)

Sabemos que a precariedade de recursos e de conhecimentos leva 0 profissional da área a uma inoperância mental, sem estímulo de aprendizagem e com a crença de já saber tudo o que é necessário, pois a repetitividade do cotidiano o leva a essa ideia. Nesse caminho de ineficiência, o governo segue promovendo programas e apostando em projetos que pouco contribuem para o desenvolvimento da saúde, esquecendo-se de injetar ânimo, divulgando melhorias, quando a realidade são hospitais cheios, sem equipe especializada para atendimento, conduzindo ao crescimento da insatisfação da população Assim, muitas vezes não é dado o valor necessário para a saúde pública nem para o profissional, esquecendose da valorização da saúde.

A situação do setor brasileiro de saúde é certamente bem mais complexa que se imagina, pois, a cada quatro anos, a quantidade de conhecimento publicado 
mundialmente duplica, e não há um adequado acompanhamento. São necessárias, portanto, iniciativas para melhorar a qualidade do ensino nessa área e ainda a divulgação dos estudos feitos. Nessa área, através da EaD, muitos esforços e recursos podem ser poupados ou otimizados, desde que estejam de acordo com as necessidades dos profissionais. (COSTA, SANTOS E BRASIL, 2004)

Saúde é direito de todos e dever do Estado (caput do art. 196 da Constituição Federal), garantida mediante ações e serviços qualificados como de relevância pública (parte inicial do art. 197 da Constituição Federal). O direito à saúde é constitucional e indisponível, garantido mediante a implementação de políticas públicas, impondo ao Estado a obrigação de criar condições objetivas que possibilitem o efetivo acesso a tal serviço com qualidade. (STF, 2010)

A ampliação dos centros de saúde e melhoria no atendimento à população através da capacitação de sua equipe é o mínimo que deve ser buscado pelo governo, que não pode se esquivar do dever de oferecer os meios necessários ao gozo do direito à saúde por todos os cidadãos. Se uma pessoa necessita de uma equipe altamente qualificada para garantir o seu direito à saúde, de tratamento médico adequado, é dever solidário da União, do Estado e do Município providenciálo através de incentivos para aprimorar os conhecimentos da equipe de saúde.

Após essa breve reflexão, conclui-se que é de extrema importância o aprimoramento contínuo do conhecimento da classe dos profissionais de saúde, levando-os a um interesse maior em seu setor, melhorando a qualidade de atendimento e tratamento ao paciente. As NTCls, incorporadas à EaD, são um grande incentivo nos processos de formação, pois geram mudanças qualitativas e quantitativas nos serviços de saúde prestados à população. Com a EaD, por meio das NTCls, há possibilidade de aplicação de diferentes recursos de aprendizagem como dissecações "tridimensionais", animações gráficas, animações interativas, tutoriais interativos, animações multimídia interativas, resolução de problemas, apresentação de casos clínicos, transmissão de imagens, e simulação clínica, resultando em aprendizagens significativas. (ABREU, 2010). Nos níveis de graduação e pós-graduação, a EaD já conquistou, no Brasil, maior credibilidade e confiabilidade e deve se tornar ferramenta importante e indispensável ao SUS. 


\subsubsection{EAD na Saúde}

A área de Saúde está se desenvolvendo e crescendo rapidamente em todos os segmentos, gerando oportunidades de trabalho para profissionais qualificados. Devido ao aumento da oferta, se faz necessário procurar atualizar e melhorar as competências permanentemente, devido ao respeito e compromisso com os princípios éticos que regem a sua conduta, na qualidade de profissional da saúde. Contudo, essa qualificação se tornou um desafio permanente, pois muitos profissionais da saúde têm a vida muito atribulada e corrida, faltando-lhes condições favoráveis para se qualificar.

Essa falta de qualificação leva a uma mão de obra despreparada e desinformada, o que conduz muitas vezes a diagnósticos e tratamentos errados por falta de conhecimento, podendo gerar situações irreversíveis. 50\% do conteúdo adquirido durante a formação acadêmica fica obsoleto até o final do curso. Isso somado à multiplicação do volume de material e novidades na área da saúde sem um acompanhamento contínuo resulta em um quadro que não é difícil de imaginar. Ainda existem desafios particulares da profissão que vão surgindo devido ao rápido progresso científico da área, como o profissional ter vários empregos ao mesmo tempo.

A atualização constante leva a benefícios para a população, como o aumento da expectativa de vida, melhorias em formas de diagnósticos e tratamentos diferenciados e eficazes. Também aumenta o nível acadêmico e informacional de toda população, causando mudança no conceito da função do profissional da saúde: o que antes era baseado na força manual, agora, com tantas informações e conhecimentos adquiridos, passa a ser baseado no conhecimento.

A Organização Mundial da Saúde diz: A formação dos profissionais de saúde deve atender às diversas preocupações com o objetivo de saná-las. Deve-se centrar o cuidado de saúde no doente, trabalhar em equipes multidisciplinares, promover a prática do profissional baseada em evidências, melhorar a aplicação das práticas, 
melhorar a utilização das tecnologias de informação e comunicação, trabalhar com incidência na resolução de problemas, divulgar prevenção de doenças e ainda promover o trabalho cooperativo e em equipe. (BRASIL, 2007)

Costa, 2012 afirma em seu artigo que a Educação à Distância na Saúde representa um caminho eficaz para a construção coletiva do conhecimento e para a melhoria das práticas dos trabalhadores, em especial se aplicado ao SUS, tendo como efeito a consolidação de um modelo mais igualitário na saúde do País. Isso leva a entender que a qualidade da saúde no Brasil está intimamente relacionada com a formação e a qualificação dos profissionais da saúde que atuam em diversas instituições de saúde. (COSTA, 2012)

O Ministério da Saúde, então, passou a adotar a Educação à Distância como prática educativa de forma estratégica para possibilitar o acesso de aproximadamente 2,5 milhões de profissionais distribuídos nos mais de 5.000 municípios brasileiros, levando em consideração as realidades específicas de cada um, contextos pessoais, institucionais e profissionais, qualificando todos da mesma forma. (BRASIL, 2007). Essa proposta do uso da EaD se configurou através da tecnologia educacional em saúde na busca de novas alternativas para melhorar a saúde, utilizando-se as NTCls, para que possam oferecer novas perspectivas a formação dos profissionais da saúde no atendimento à população, proporcionando competência e qualidade nos conhecimentos adquiridos pela EaD.

O avanço das tecnologias de informação e comunicação modificou e ainda deve modificar profundamente todo o estilo de vida, pois altera nossa forma de conviver e trabalhar, introduz novos valores, hábitos e tipos de interação social, utilizando essa nova forma de ensinar e aprender. Existem autores que confirmam que a utilização da $\mathrm{EaD}$ na saúde no Brasil já tem disseminado conhecimento a regiões inóspitas do Brasil, levando a mesma qualidade de informações para todos, sem discriminação. Então, devemos estimular mais e mais a procura por formação e qualificação desta mão de obra, especialmente por meio da $\mathrm{EaD}$, utilizando as NTCls. 


\subsection{DEFINIÇÕES DE PESQUISA QUALITATIVA E QUANTITATIVA}

Santos, 2015 apud Minayo, 1994, define: "a pesquisa qualitativa responde a questões muito particulares". Esse tipo de estudo tem a abordagem do tipo que "trabalha com o universo de significados, motivos, aspirações, crenças, valores e atitudes, que corresponde a um espaço mais profundo das relações, dos processos e dos fenômenos que não podem ser reduzidos a operacionalização de variáveis".

Dessa forma, quando se fala de pesquisa qualitativa, está se referindo a uma forma de conhecer o mundo através dos procedimentos conhecidos como qualitativos, que entende que o conhecimento não é isento de valores, de intenção e da história de vida do pesquisador, e muito menos das condições sociopolíticas do momento.

No dicionário informal, a pesquisa quantitativa está definida como tudo pode ser quantificável, o que significa traduzir em números opiniões e informações para classificá-las e analisá-las. Requer o uso de recursos e de técnicas estatísticas.

Como já dizia Paulo Freire: a escolha da pergunta de pesquisa já é, em si, um ato embebido de subjetividade. Pode-se dizer que as abordagens quantitativa e qualitativa tendem à complementariedade.

Santos, 2015, apud Minayo, 1994, que afirma que "o conjunto de dados quantitativos e qualitativos (...) não se opõem. Ao contrário, se complementam, pois, a realidade abrangida por eles interage dinamicamente, excluindo qualquer dicotomia".

Outros autores apoiam as ideias supramencionadas. Para Ludke e André (1986), "o estudo qualitativo (...) é o que se desenvolve numa situação natural, é rico em dados descritivos, tem um plano aberto e flexível e focaliza a realidade de forma complexa e contextualizada". Os autores também mencionam que o foco deste gênero de pesquisas é muito mais o processo do que o produto: "o interesse do pesquisador ao estudar um determinado problema é verificar como ele se manifesta nas atividades, nos procedimentos e nas interações cotidianas", com vistas a acatar a complexidade presente nos contextos variados. 
Qualidade, segundo o dicionário Aurélio, é "propriedade, atributo ou condição das coisas ou das pessoas que as distingue das outras e lhes determina a natureza".

A busca pela qualidade de qualquer procedimento em qualquer área se constitui na maior preocupação das organizações, na atualidade, destacando-se os principais objetivos das organizações em relação ao controle da qualidade e à real necessidade de adoção de novas estratégias administrativas, educativas e pessoais com a finalidade de alcançar um só objetivo, o atendimento de excelência. (SILVA, 1994).

O Ministério da Educação entende que qualidade em IES seria um conjunto de atributos que existem no centro das instituições, aliado ao cumprimento de seus deveres, que alcancem as expectativas de seus alunos e da sociedade, atingindo padrões aceitáveis de desempenho que levam a uma satisfação. (MEC, CONAES, INEP, 2006)

\subsubsection{Definição de Satisfação}

A satisfação, traduzida em palavras, seria sentimento de prazer ou de desapontamento em relação à eficiência de algo ou produto, considerando as expectativas do cliente. (KOTLER, 2007).

Com base nessa definição, a satisfação do aluno de EaD, que é o principal elemento para a geração de resultados em seu aprendizado, será alcançada dentro do processo de ensino-aprendizagem de acordo com os resultados de sua avaliação, de atitudes do aluno dentro do curso e, ainda, sua interação com professor e colegas de curso. (Marks, Sibley e Arbaugh (2005).

Segundo Marks, Sibley e Arbaugh (2005), a satisfação em cursos pela EaD, é consideravelmente influenciada pelo comportamento e atitudes dos professores, tutores e monitores, pois possuem extrema importância na condução do curso com dinamismo, integração e motivação constante dos alunos. Deve-se ainda conhecer o 
perfil dos alunos, seus anseios e necessidades, para que assim se possa chegar o mais próximo de suas expectativas em relação ao curso.

O autor Grasel (2000), apud Marcuzzo, 2013, interliga qualidade com satisfação, concordando que, se o curso tem uma boa qualidade, se torna mais fácil para o aluno encontrar satisfação nele. Sendo assim, ele diz que um curso, para ser considerado de qualidade, precisa de melhorias no processo ensino-aprendizagem e também nas instalações presentes na instituição, como: instalações precisas, estrutura de qualidade, serviços acadêmicos, suporte financeiro viável, política de avaliação institucional, oferta de vagas, jornada de trabalho, qualificação do docente e interação professor/aluno, tutor/aluno e aluno/aluno, entre outras.

O aluno jamais deve ser visto como um mero cliente, ou como uma matéria prima a ser trabalhada, mas deve ser visto como peça primordial no processo de ensino-aprendizagem, pois tem de ser reconhecido como parte inteiramente ativa, podendo até ser considerado como sócio da instituição. Logo, para manter a qualidade do ensino prestado pela Educação à Distância, é necessário compreender as variáveis que influenciam diretamente na satisfação dos alunos.

Então, conclui-se que a satisfação do aluno é um componente indispensável para adquirir conhecimento através do processo ensino-aprendizagem por EaD. Se o aluno está satisfeito, todos os outros fatores estão presentes, senão a maioria deles, o que leva ao aumento de confiança na instituição e na equipe de professores, facilita a interação aluno/conteúdo e causa grande impacto na qualidade do processo educativo.

Conclui-se que a satisfação do aluno e a qualidade do curso estão ligadas ao atendimento das expectativas e anseios dos alunos. (MARCUZZO, 2013) 


\section{OBJETIVO}

O objetivo do presente estudo foi avaliar a satisfação dos alunos da área de Saúde em relação a uma disciplina semipresencial Tópicos Avançados em Promoção e Saúde - TAPS a partir de uma análise quantitativa e qualitativa por meio da aplicação de um questionário. Os objetivos específicos foram:

1. Caracterizar o perfil dos alunos participantes da disciplina TAPS;

2. Identificar e confirmar os principais fatores que explicam a satisfação dos alunos participantes da disciplina;

3. Identificar as dimensões que determinam a satisfação dos alunos;

4. Identificar os aspectos facilitadores e dificultadores enfrentados pelos alunos no processo ensino-aprendizagem de uma disciplina semipresencial. 


\section{METODOLOGIA}

\subsection{DELINEAMENTO DA PESQUISA}

Esta pesquisa foi um estudo de caráter qualitativo e quantitativo que visou avaliar a satisfação na Educação à Distância dos alunos da área de saúde em uma disciplina semipresencial. Foi aprovado pelo Comitê de ética em pesquisa da Faculdade de Ciências da Saúde, sob o número de CAAE 43690414.2.0000.0030.

A pesquisa foi realizada via internet na Universidade de Brasília, que oferece disciplinas à distância semipresenciais, na área de saúde para os cursos de Enfermagem, Farmácia, Medicina, Fisioterapia, Gestão em Saúde, Terapia Ocupacional, Fonoaudiologia, Ciências Farmacêuticas, Educação Física, Nutrição, Odontologia e Psicologia.

A pesquisa consistiu em um levantamento censitário voluntário, com aceite dos participantes por meio do Termo de Consentimento Livre e Esclarecido - TCLE em uma página para esse fim. Foram abordados alunos de graduação da área de saúde que optaram por cursar a matéria Tópicos Avançados em Promoção e Saúde - TAPS, por meio de resposta a um questionário. Esse trabalho foi realizado via email enviado pela própria autora da dissertação e aluna de mestrado na UnB em ciências da saúde. Não houve nenhum tipo de contato prévio com os alunos envolvidos no estudo. A pesquisadora foi conhecida através do e-mail enviado juntamente com o questionário, explicando quem era e apresentando as suas intenções com a pesquisa.

Previamente ao início do questionário, era apresentado ao voluntário o Termo de Consentimento Livre e Esclarecido - TCLE. Caso tivesse interesse em participar da pesquisa, era necessário concordar com o termo, e o voluntário marcava a caixa referente à aceitação. Em seguida, iniciava-se a aplicação do questionário. A coleta de dados foi realizada por meio do link, https://docs.google.com/forms/d/107VMMQLLVgagh4ydViLagapkScM8KLOS1e8nUwfRcsM/viewform?c=0 


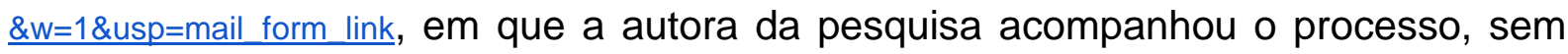
interrupções.

\subsection{DESCRIÇÃO DA DISCIPLINA TÓPICOS AVANÇADOS EM PROMOÇÃO E SAÚDE}

A definição de TAPS do próprio sítio eletrônico sem nenhuma alteração diz: " $A$ Disciplina de Tópicos Avançados em Promoção da Saúde 1 (TAPS1) é uma iniciativa interinstitucional, construída interdisciplinarmente, sob o enfoque filosófico multiprofissional, acrescido da estratégia de educação via rede, como experiência inovadora, crítica e ousada."

TAPS é uma matéria optativa oferecida através do Moodle, modalidade virtual, para alunos da graduação na UnB. Tem como objetivo primordial oferecer ao aluno uma aprendizagem construída coletivamente com sua maior participação. A disciplina disponibilizava um professor responsável. Nesse caso foi o professor Dr. Elioenai Dornelles Alves, que tinha 10 Tutores, 1 (um) para cada turma com 20 alunos, e ainda 20 monitores, sendo 2 para cada 20 alunos.

Uma vez participante do curso do Nesprom - TAPS, o estudante ingressava no Ambiente Virtual através de seu nome de acesso e senha pessoal e intransferível ao sistema (login). Todos os envolvidos no curso, professores, tutores, monitores e alunos, têm a necessidade de preencher uma descrição pessoal, na seção "Perfil" de acordo com aquilo que interesse a cada um expor sobre si, e deve ser colocada uma foto. A trajetória de cada um dos participantes é registrada e pode ser acompanhada através do tópico localizado à esquerda da tela $\rightarrow$ Minhas configurações de perfil $\rightarrow$ relatórios das atividades $\rightarrow$ todos os acessos.

A primeira interface a que tem contato é com a página inicial que mostra, no canto esquerdo, os tópicos. O primeiro é o de mensagens, o segundo é de navegação pelo sítio eletrônico, o terceiro é o de Administração, em que estão as 
configurações que o aluno fez do seu perfil, inclusive a inserção de uma foto recente, e o próximo tópico mostra os usuários on-line. No meio da página se encontra a categoria dos cursos oferecidos (Figura 2). Logo abaixo estão os cursos em que o aluno está inserido e um quadro de busca de todos os cursos abertos.

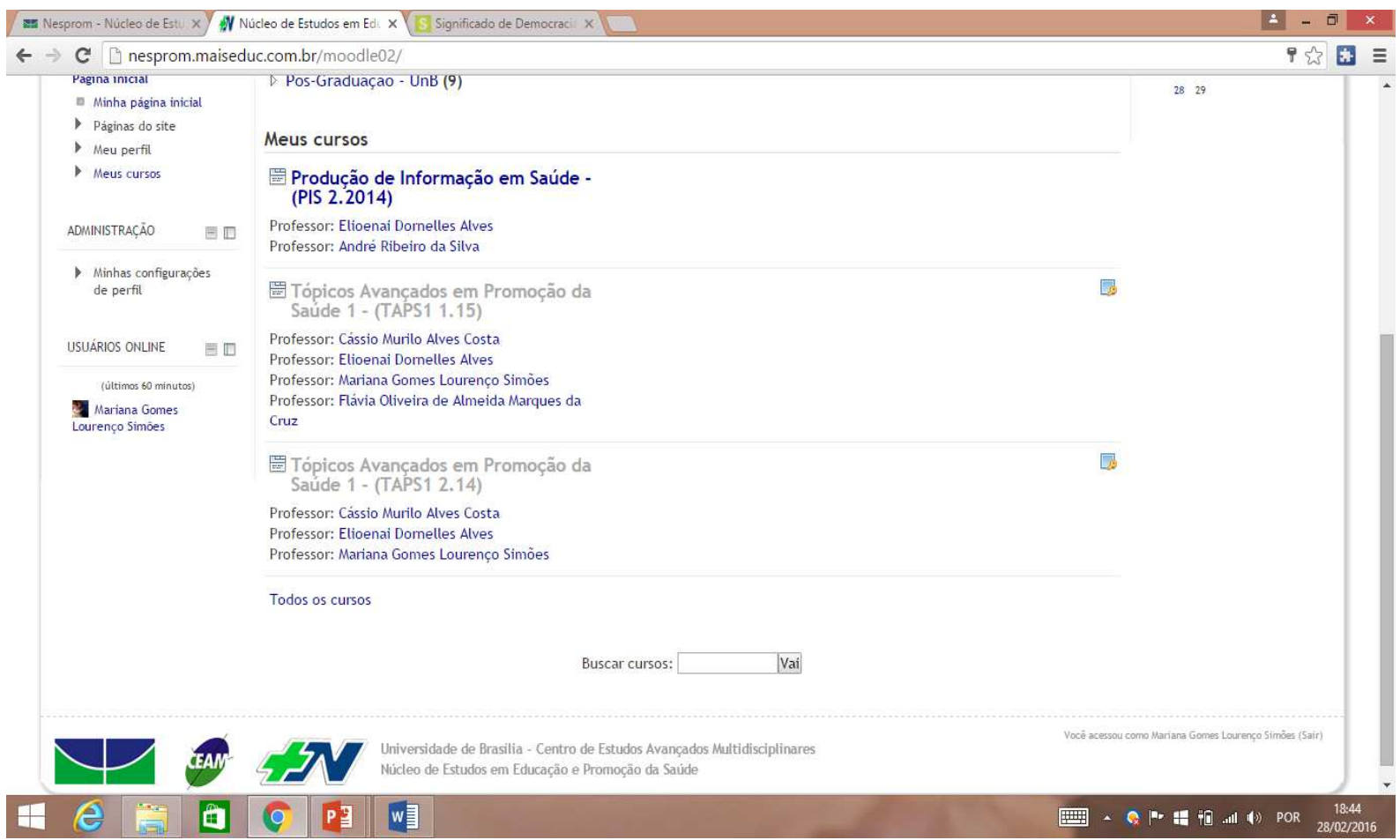

Figura 2 - Interface mostrando os cursos em EaD na plataforma NESPROM.

Ao lado direto, no canto superior, se encontra um calendário, em que fica ajustada e marcada a data de um encontro presencial, para que o aluno veja logo que entrar na plataforma. Ao acessar, meu curso atual, abre-se a página do curso e nela o aluno encontra primeiramente uma descrição do curso (Figura 3). A descrição contém o nome da matéria, o local em que está hospedado, o período letivo, os dias de aulas presenciais, o código da disciplina, a quantidade de créditos, a data de início e os professores e tutores da disciplina. 


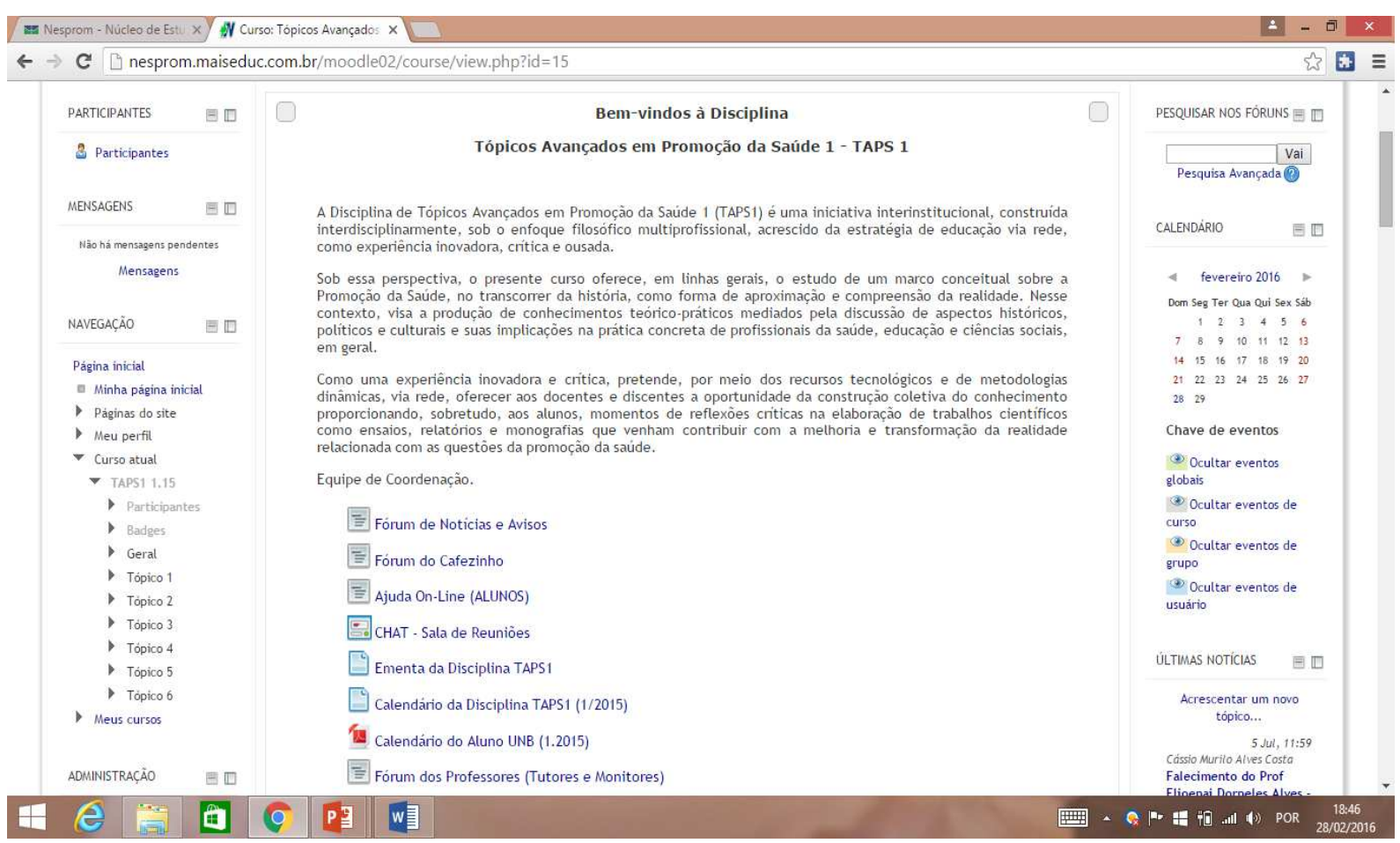

Figura 3 - Interface da disciplina TAPS.

Abaixo o aluno encontrará os tópicos (Figuras 4, 5 e 6). Dentro desses tópicos, em cada um, se encontram os materiais que serão utilizados durante a disciplina, que podem ser acessados. Também encontrará tópicos de fórum de dúvidas, apresentações, Netiquetas (Etiquetas básicas para o mundo virtual), planejamento da disciplina, fórum de notícias, datas de encontros presenciais e o famoso espaço de cafezinho entre amigos. Este último proporciona um ambiente de interação, que permite o agendamento de reuniões virtuais em tempo real entre os participantes do curso, seja para a discussão de algum tema relevante, relacionado às atividades transcorridas nas disciplinas ou não, servindo para melhorar a interação entre alunos. Mais abaixo estão os tópicos das matérias para estudos e para a postagem de atividades com data de entrega definida, que será avaliado pelo tutor (Figura 5). 


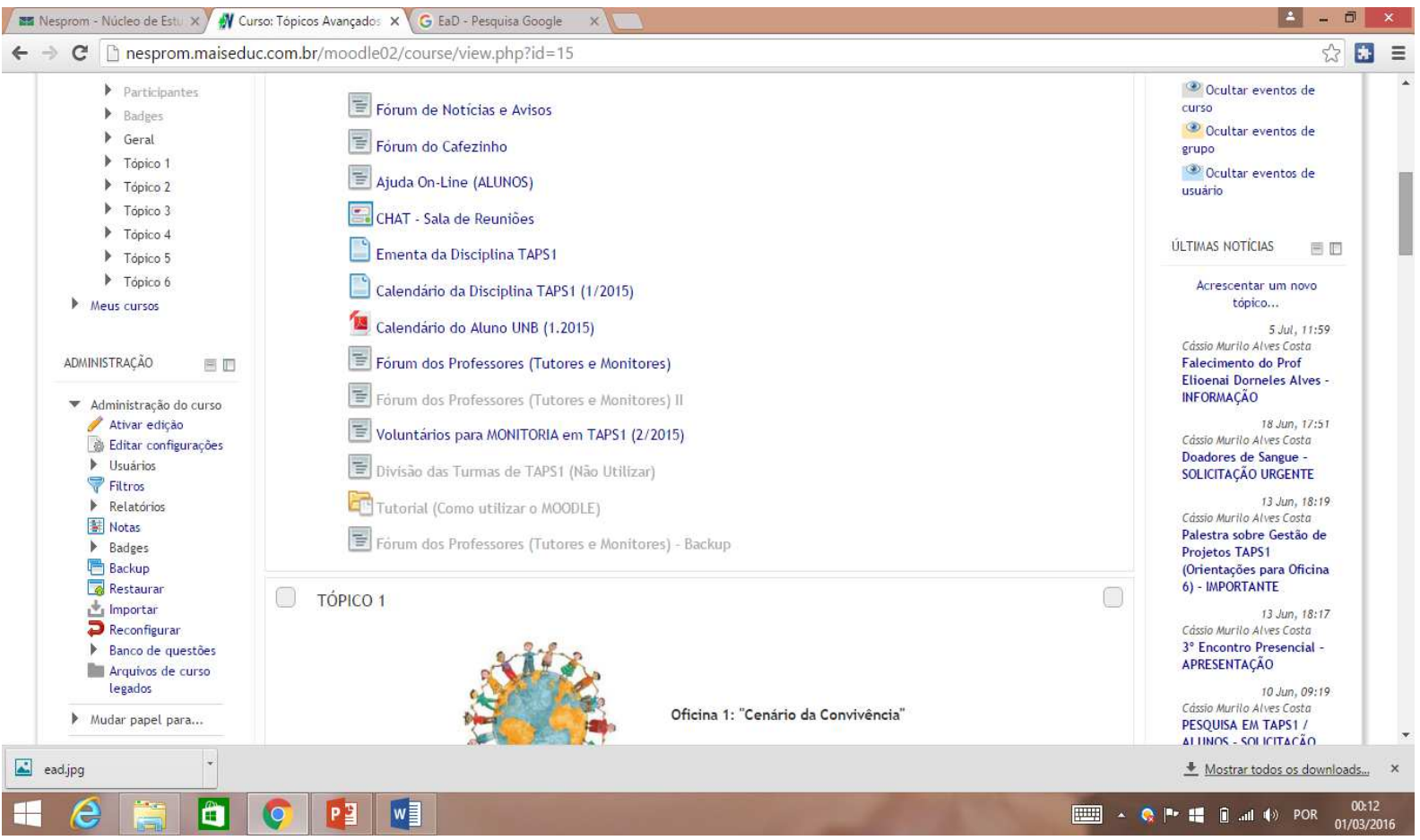

Figura 4 - Interface da disciplina TAPS indicando os tópicos.

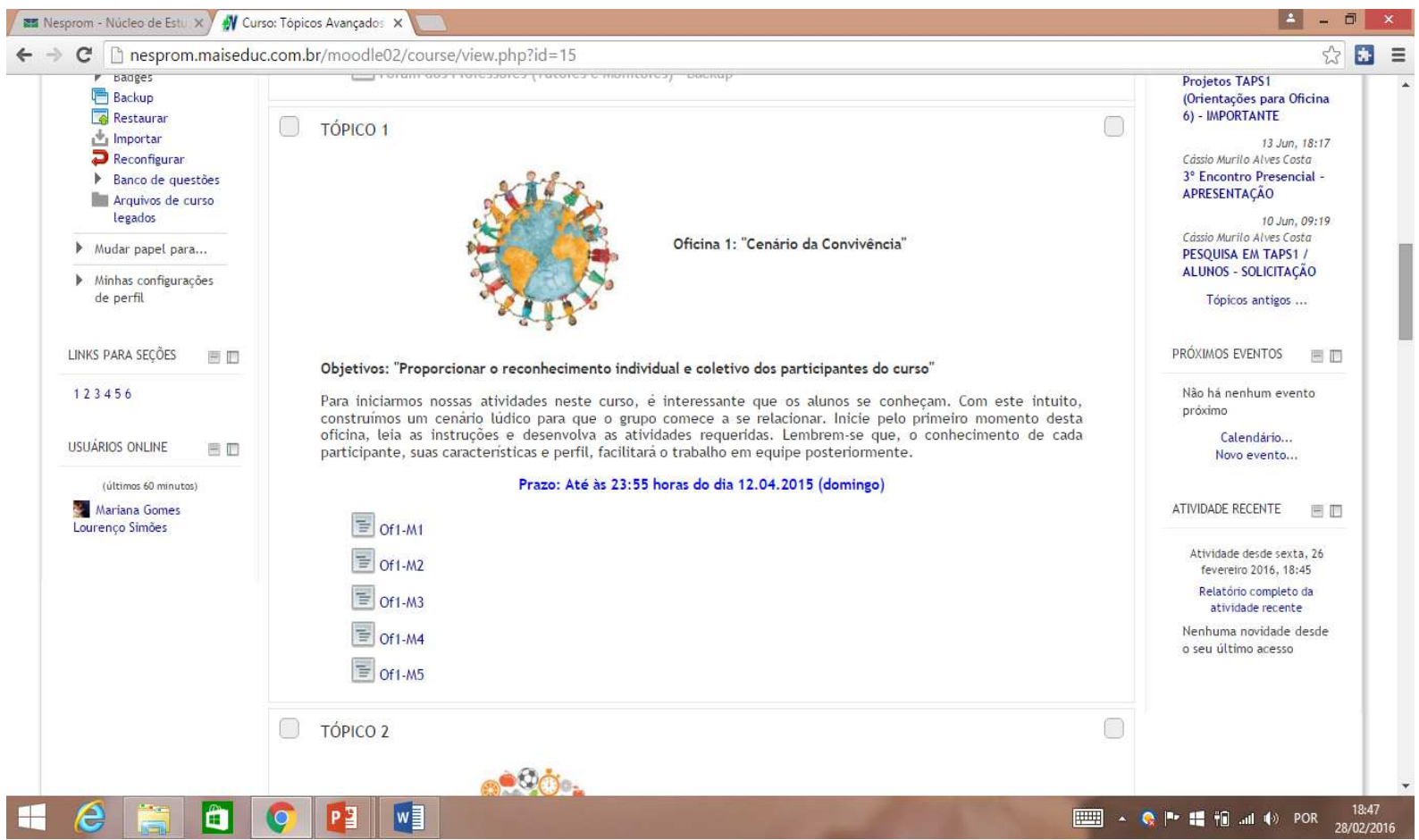

Figura 5 - Interface da disciplina TAPS indicando a oficina 1. 


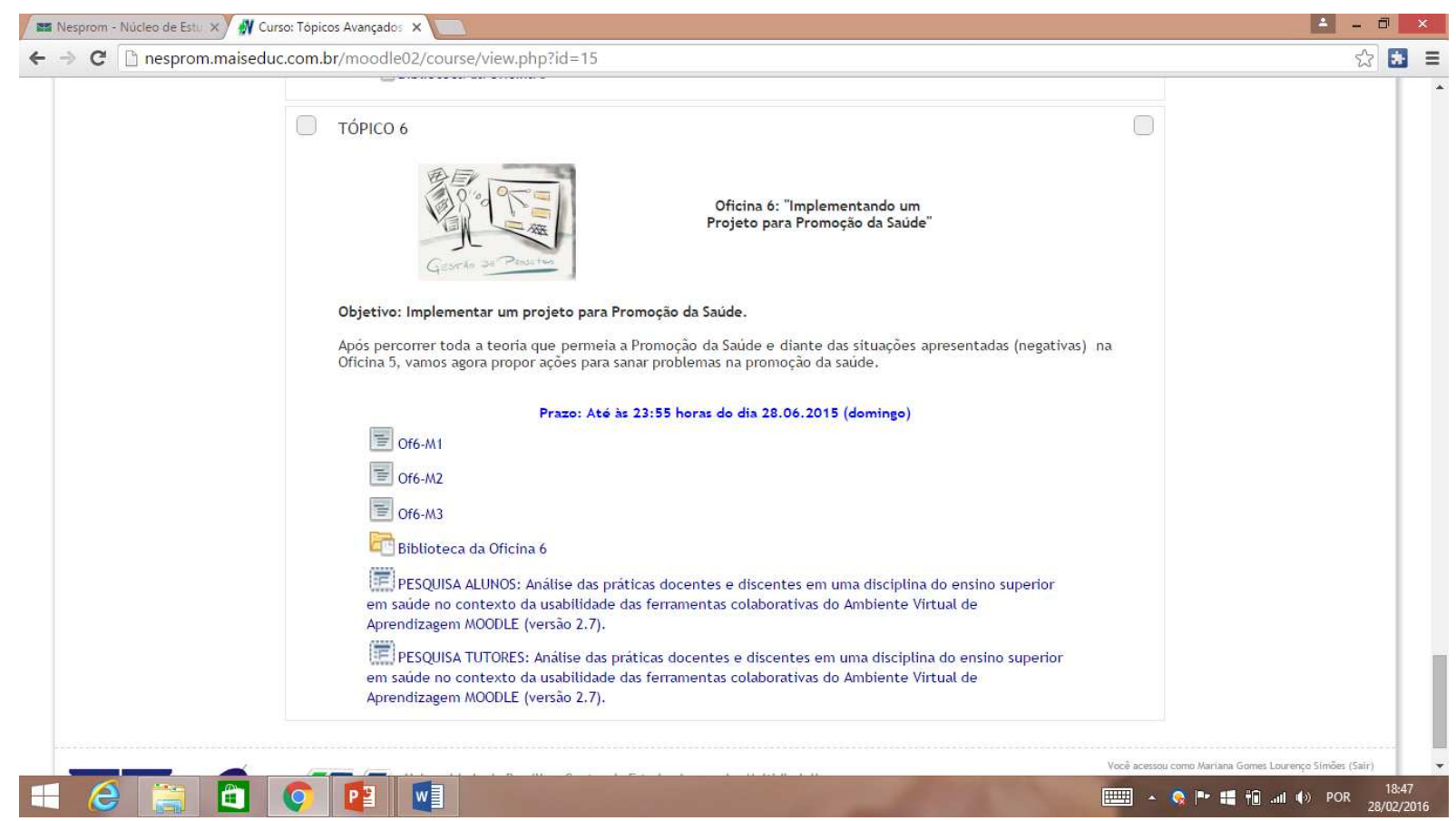

Figura 6 - Interface da disciplina TAPS indicando a oficina 6.

A ambientação on-line acontece na fase inicial do curso, dura em torno de três dias, em que os alunos são estimulados a ser adaptarem ao ambiente Moodle e a conhecer o grupo do qual fazem parte. Inicia-se com a apresentação individual e a participação na apresentação dos colegas com comentários estimuladores, conhecendo a todos. Ainda o tutor responsável envia uma mensagem convidando todos a conhecerem, explorarem a plataforma, explorarem as ferramentas disponíveis, induzindo a uma participação intensa de todos: alunos, tutores, monitores e professores. O tutor responsável pela turma se coloca à disposição para o esclarecimento de dúvidas, indicando o modo pelo qual os questionamentos devem ser encaminhados.

A pesquisa da matéria TAPS foi feita com alunos do $2^{\circ}$ semestre de 2014 e $1^{\circ}$ semestre de 2015. Durante esse período, a disciplina aconteceu da seguinte forma: foram feitos três encontros presenciais de todos os alunos. Na primeira semana de aula, houve o primeiro encontro, para explicar a metodologia e para a apresentação dos alunos, professor, tutor e a formação dos grupos. Os outros dois encontros presenciais foram para apresentar seminários avaliativos do processo de ensinoaprendizagem e para a finalização do curso, com presença obrigatória e avaliativa. 
A disciplina foi dividida em seis oficinas durante um semestre, e cada oficina teve cinco momentos (Tarefas), cada qual com duração de uma semana, com início sempre às $0 h$ de segunda-feira, com finalização às $23 h 55$ do domingo seguinte, para postagens e respostas aos exercícios propostos. As oficinas 1, 2 e 3 foram feitas com a ideia de estimular o aluno a construir seu conhecimento, juntando todas as reflexões do grupo. Na quarta oficina, aconteceu uma fusão de momentos. O momento 1 e 2 caminharam juntos, finalizando ambos duas semanas mais tarde. $O$ terceiro, o quarto e o quinto momentos foram baseados em críticas construtivas e só finalizaram quando completou um mês. A pontuação e a avaliação do aluno foram feitas pelo monitor e conferidas pelo tutor, de acordo com a correção do que foi postado dentro do prazo estipulado. Se o aluno postasse fora do prazo existia uma penalização de perda de pontos. Caso fosse identificado plágio, a nota atribuída ao aluno era sempre 0,0 .

A primeira oficina começou com as apresentações dos alunos $\mathrm{e}$ autoconhecimento chamado de Cenário da Convivência, feito através de um cenário lúdico com animais, para que o grupo começasse a se conhecer, isso foi realizado através de 5 momentos.

A segunda oficina foi Conceitos de Saúde e teve como objetivo levar o aluno a discutir e a construir o que é saúde e a definir os seus conceitos. A terceira oficina, Raízes da Promoção da Saúde, teve como ideia levar à construção de um conhecimento sobre os conceitos da promoção de saúde. Todo esse conhecimento foi embasado com artigos, reportagens e vídeos sobre o assunto, que estavam à disposição dos alunos através da Bibliografia recomendada, com a ideia de aprimorar a busca para além do que foi indicado.

A quarta oficina, Interagindo com a Promoção da Saúde, aparece de uma forma diferente, com a proposta de levar os alunos a uma reflexão coletiva sobre os marcos da Promoção da Saúde no Mundo e na América Latina. Isso foi feito através da fusão de momentos: o $1^{\circ}$ junto com o $2^{\circ}$, e $\circ 3^{\circ}$ momento juntamente com o $4^{\circ} \mathrm{e}$ o 5 momentos. Os primeiros momentos foram realizados através de um trabalho em grupo, no qual a divisão foi feita pelos tutores e repassada aos alunos. Os momentos restantes foram trabalhos individuais. 
A quinta oficina voltou a sua origem em forma, A Promoção da Saúde no Brasil, com o intuito de analisar o desenvolvimento da promoção de saúde na nação brasileira, verificando a existência de coerência nas ações voltadas para a saúde, levando a um questionamento construtivo com intuito de mudança futura.

O sexto momento, Implementando um Projeto para Promoção da Saúde, levou o aluno a utilizar os pontos negativos apresentados na oficina 5 , propondo soluções para os problemas nos momentos 1 a 3 . E no momento 4 existia uma pesquisa intitulada: PESQUISA ALUNOS: Análise das práticas docentes e discentes em uma disciplina do ensino superior em saúde no contexto da usabilidade das ferramentas colaborativas do Ambiente Virtual de Aprendizagem Moodle; e PESQUISA TUTORES: Análise das práticas docentes e discentes em uma disciplina do ensino superior em saúde no contexto da usabilidade das ferramentas colaborativas do Ambiente Virtual de Aprendizagem Moodle. Essa pesquisa da plataforma não foi utilizada em nenhum dos pontos desta pesquisa.

As oficinas e os momentos estão exemplificados no fluxograma abaixo pelas Figuras 7 e 8 . 


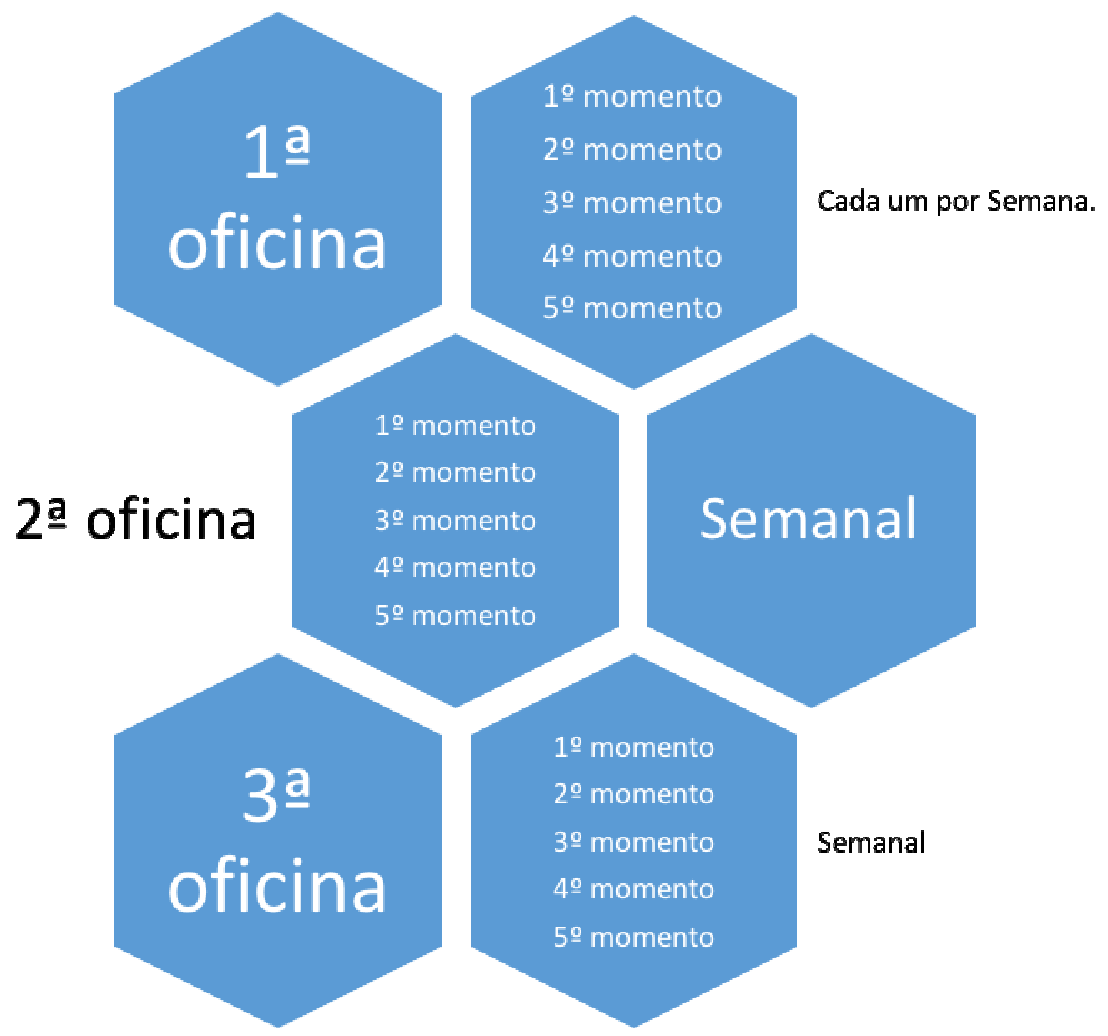

Figura 7 - Fluxograma das oficinas de TAPS, oficinas 1 a 3.

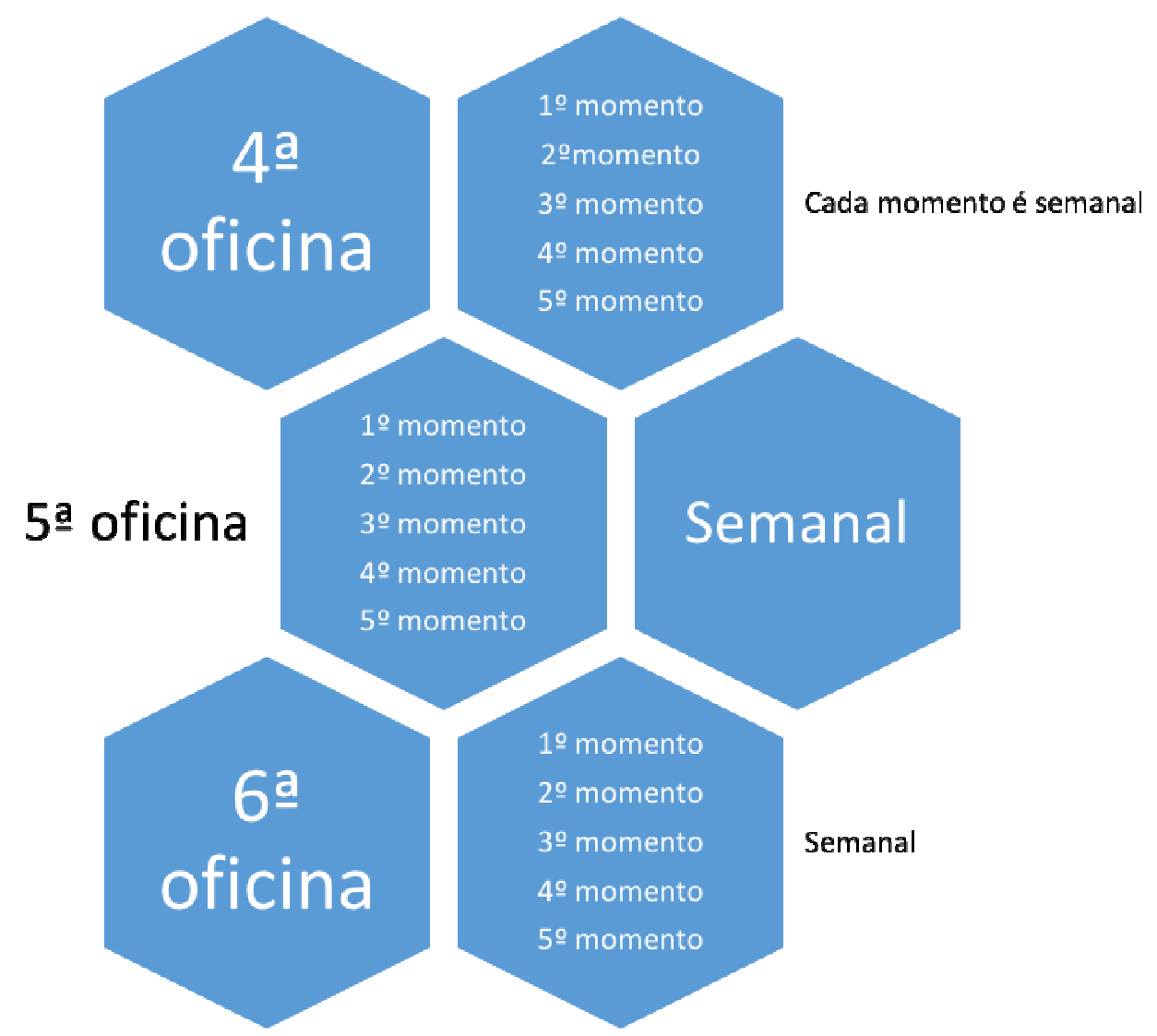

Figura 8 - Fluxograma das oficinas de TAPS, oficinas 4 a 6 . 
A relação e interação existente entre os componentes da disciplina TAPS, professor, tutor, monitor e aluno, era feita, na sua grande maioria, preferencialmente pela plataforma, podendo acontecer por outro meio de comunicação, dependendo da gravidade da questão.

\subsection{CRITÉRIOS DE INCLUSÃO}

Foram observados os seguintes critérios de participação (inclusão) desta pesquisa:

- Aluno matriculado em TAPS no $2^{\circ}$ semestre de 2014 e no $1^{\circ}$ semestre de 2015;

- Aluno de curso de graduação da área da saúde;

- Aceite ao TCLE;

- Presença superior a $75 \%$.

\subsection{CRITÉRIOS DE EXCLUSÃO}

Foram excluídos os alunos que não preenchiam todos os critérios de inclusão, como não completar o curso e não ser da área da saúde.

\subsection{AMOSTRA}

Foi abordado via e-mail o total de 280 alunos. Desses, apenas 107 eram alunos da área de Saúde. Foram respondidos 69 questionários, sendo 1 ainda de 
aluno fora da área da Saúde e outros 3 duplicados. Ao final, 65 questionários foram considerados válidos para a análise, o que corresponde a aproximadamente $61 \%$ da amostra inicial.

\subsection{APLICAÇÃO DO QUESTIONÁRIO}

O questionário foi aplicado via e-mail no período de 08/10/2015 a 05/11/2015 por meio de no máximo 5 tentativas que foram feitas somente via e-mail. Todos os alunos da área de saúde foram incluídos, sendo a amostra constituída por todo o universo.

O tempo necessário para responder o questionário foi em torno de 20 minutos, incluindo as perguntas discursivas, de forma que não houve saturação dos dados e não foi devolvida nenhuma transcrição para os participantes para correção ou comentários.

\subsection{DESCRIÇÃO DO QUESTIONÁRIO}

O questionário aplicado aos alunos foi desenvolvido pela aluna de Mestrado juntamente com o Prof. Dr. Elioenai Dornelles Alves. Esse instrumento não foi validado, sendo o mesmo utilizado na presente pesquisa com o objetivo de identificar os possíveis fatores que influenciam a satisfação dos alunos da área de saúde durante o curso de uma disciplina semipresencial de forma qualitativa e quantitativa.

O questionário foi dividido em 3 sessões, sendo a sessão A constituída por 12 perguntas fechadas (A1-A12), a sessão B por 10 perguntas fechadas (B1-B10) e a 
sessão $C$ por 33 perguntas fechadas (C1-C33) e duas perguntas semiabertas, pois se limitava o número de respostas (C34-C35). O questionário está apresentado abaixo no quadro 3 .

Quadro 3: Questionário aplicado

\begin{tabular}{|l|l|}
\hline A1) Qual sua idade? & a) Menos de 20 \\
anos. & b) 20 a 30 anos. \\
c) 31 a 40 anos. \\
d) 40 a 50 anos. \\
e) 50 anos ou \\
mais.
\end{tabular}




\begin{tabular}{|c|c|}
\hline cidade, ela se situava em uma região? & b) Interior. \\
\hline $\begin{array}{l}\text { A9) Qual seu conhecimento em relação à utilização do } \\
\text { computador? }\end{array}$ & $\begin{array}{l}\text { a) Nenhum. } \\
\text { b) Pouco. } \\
\text { c) Bom. } \\
\text { d) Ótimo. }\end{array}$ \\
\hline $\begin{array}{l}\text { A10) Você possui computador com acesso a internet } \\
\text { em sua residência? }\end{array}$ & $\begin{array}{l}\text { a) Sim. } \\
\text { b) Não. }\end{array}$ \\
\hline $\begin{array}{l}\text { A11) Em que local você desenvolve suas atividades } \\
\text { acadêmicas no Ambiente Virtual? }\end{array}$ & $\begin{array}{l}\text { a) Na UnB. } \\
\text { b) Minha } \\
\text { residência. } \\
\text { c) Meu trabalho. } \\
\text { d) Lan House. } \\
\text { e) Outro. } \\
\end{array}$ \\
\hline $\begin{array}{l}\text { A12) Este curso é o seu primeiro em graduação on- } \\
\text { line? }\end{array}$ & $\begin{array}{l}\text { a) Sim. } \\
\text { b) Não, já sou } \\
\text { formado em uma } \\
\text { graduação } \\
\text { presencial. } \\
\text { c) Não, já sou } \\
\text { formado em outra } \\
\text { graduação pela } \\
\text { EaD. }\end{array}$ \\
\hline B1) Os professores demonstram domínio do conteúdo? & $\begin{array}{l}\text { a) Sim. } \\
\text { b) Não. }\end{array}$ \\
\hline $\begin{array}{l}\text { B2) Os professores esclarecem prontamente minhas } \\
\text { dúvidas? }\end{array}$ & $\begin{array}{l}\text { a) Sim. } \\
\text { b) Não. }\end{array}$ \\
\hline $\begin{array}{l}\text { B3) Os professores são acessíveis fora do horário do } \\
\text { chat ou atividades planejadas on-line? }\end{array}$ & $\begin{array}{l}\text { a) Sim. } \\
\text { b) Não. }\end{array}$ \\
\hline $\begin{array}{l}\text { B4) Os professores apresentam os planos de ensino, } \\
\text { elucidando os objetivos das disciplinas? }\end{array}$ & $\begin{array}{l}\text { a) Sim. } \\
\text { b) Não. }\end{array}$ \\
\hline B5) Os professores são assíduos e pontuais? & $\begin{array}{l}\text { a) Sim. } \\
\text { b) Não. }\end{array}$ \\
\hline $\begin{array}{l}\text { B6) Os professores demonstram interesse no } \\
\text { aprendizado dos alunos? }\end{array}$ & $\begin{array}{l}\text { a) Sim. } \\
\text { b) Não. }\end{array}$ \\
\hline $\begin{array}{l}\text { B7) As explicações dadas pelos professores parecem } \\
\text { claras e adequadas? }\end{array}$ & $\begin{array}{l}\text { a) Sim. } \\
\text { b) Não. }\end{array}$ \\
\hline $\begin{array}{l}\text { B8) Os professores relacionam os conteúdos } \\
\text { trabalhados com a realidade? }\end{array}$ & $\begin{array}{l}\text { a) Sim. } \\
\text { b) Não. }\end{array}$ \\
\hline $\begin{array}{l}\text { B9) Existe um alto nível de interatividade entre } \\
\text { professor/ tutor e alunos? }\end{array}$ & $\begin{array}{l}\text { a) Sim } \\
\text { b) Não. }\end{array}$ \\
\hline $\begin{array}{l}\text { B10) A avaliação (provas, acessos a chats, fóruns, etc.) } \\
\text { serve mais para controlar e classificar o aluno do que } \\
\text { como um processo de correção de rumos e construção } \\
\text { do conhecimento? }\end{array}$ & $\begin{array}{l}\text { a) Sim. } \\
\text { b) Não }\end{array}$ \\
\hline $\begin{array}{l}\text { C1) O Ambiente Virtual de Aprendizagem favorece a } \\
\text { interatividade entre acadêmicos e docentes? }\end{array}$ & $\begin{array}{l}\text { a) Sim. } \\
\text { b) Não. }\end{array}$ \\
\hline $\begin{array}{l}\text { C2) O Ambiente Virtual de Aprendizagem favorece a } \\
\text { interatividade entre acadêmicos e tutores? }\end{array}$ & $\begin{array}{l}\text { a) Sim. } \\
\text { b) Não. }\end{array}$ \\
\hline C3) O Ambiente Virtual de Aprendizagem incentiva a & a) Sim. \\
\hline
\end{tabular}




\begin{tabular}{|c|c|}
\hline comunicação entre colegas? & b) Não. \\
\hline $\begin{array}{l}\text { C4) O Ambiente Virtual de Aprendizagem permite ao } \\
\text { estudante resolver, com rapidez, questões referentes } \\
\text { ao material didático e seus conteúdos? }\end{array}$ & $\begin{array}{l}\text { a) Sim. } \\
\text { b) Não. }\end{array}$ \\
\hline C5) O modelo de tutoria na disciplina é adequado? & $\begin{array}{l}\text { a) Sim. } \\
\text { b) Não. }\end{array}$ \\
\hline $\begin{array}{l}\text { C6) O número de professores/hora disponíveis para os } \\
\text { atendimentos requeridos pelos estudantes é } \\
\text { adequado? }\end{array}$ & $\begin{array}{l}\text { a) Sim. } \\
\text { b) Não. }\end{array}$ \\
\hline $\begin{array}{l}\text { C7) A quantidade de estudantes atendida pelo tutor é } \\
\text { adequada? }\end{array}$ & $\begin{array}{l}\text { a) Sim. } \\
\text { b) Não. }\end{array}$ \\
\hline $\begin{array}{l}\text { C8) Os momentos presenciais são planejados e } \\
\text { informados aos estudantes com antecedência? }\end{array}$ & $\begin{array}{l}\text { a) Sim. } \\
\text { b) Não. }\end{array}$ \\
\hline $\begin{array}{l}\text { C9) Os recursos didáticos utilizados na disciplina são } \\
\text { de boa qualidade? }\end{array}$ & $\begin{array}{l}\text { a) Sim. } \\
\text { b) Não }\end{array}$ \\
\hline $\begin{array}{l}\text { C10) Há compatibilidade da avaliação da aprendizagem } \\
\text { com o conteúdo trabalhado? }\end{array}$ & $\begin{array}{l}\text { a) } \operatorname{Sim} \\
\text { b) Não. }\end{array}$ \\
\hline $\begin{array}{l}\text { C11) Há diversidade de instrumentos de avaliação } \\
\text { (provas, trabalhos, etc.)? }\end{array}$ & $\begin{array}{l}\text { a) Sim. } \\
\text { b) Não. }\end{array}$ \\
\hline $\begin{array}{l}\text { C12) No desenvolvimento da disciplina fica garantida a } \\
\text { relação teoria-prática, respeitadas as especificidades } \\
\text { da disciplina? }\end{array}$ & $\begin{array}{l}\text { a) } \operatorname{Sim} \\
\text { b) Não }\end{array}$ \\
\hline $\begin{array}{l}\text { C13) Os trabalhos de grupo desenvolvidos na disciplina } \\
\text { atingiram os objetivos a que se propuseram? }\end{array}$ & $\begin{array}{l}\text { a) Sim. } \\
\text { b) Não. }\end{array}$ \\
\hline $\begin{array}{l}\text { C14) A carga horária é compatível com o conteúdo da } \\
\text { disciplina? }\end{array}$ & $\begin{array}{l}\text { a) Sim. } \\
\text { b) Não. }\end{array}$ \\
\hline $\begin{array}{l}\text { C15) Há disponibilidade de tempo para o estudo e } \\
\text { desenvolvimento de atividades relacionadas à } \\
\text { disciplina? }\end{array}$ & $\begin{array}{l}\text { a) Sim. } \\
\text { b) Não. }\end{array}$ \\
\hline $\begin{array}{l}\text { C16) Os conteúdos da disciplina estão relacionados } \\
\text { com os conteúdos das demais disciplinas que } \\
\text { compõem o todo da profissão? }\end{array}$ & $\begin{array}{l}\text { a) Sim. } \\
\text { b) Não. }\end{array}$ \\
\hline $\begin{array}{l}\text { C17) O material didático indicado para a disciplina é de } \\
\text { boa qualidade? }\end{array}$ & $\begin{array}{l}\text { a) Sim. } \\
\text { b) Não. }\end{array}$ \\
\hline $\begin{array}{l}\text { C18) Há repetição de conteúdos já abordados em } \\
\text { outras disciplinas? }\end{array}$ & $\begin{array}{l}\text { a) Sim. } \\
\text { b) Não. }\end{array}$ \\
\hline $\begin{array}{l}\text { C19) O curso oferece atividades de aplicação prática } \\
\text { dos conteúdos estudados? }\end{array}$ & $\begin{array}{l}\text { a) Sim. } \\
\text { b) Não. }\end{array}$ \\
\hline $\begin{array}{l}\text { C20) A disciplina proporciona aos estudantes a } \\
\text { oportunidade de desenvolver projetos compartilhados? }\end{array}$ & $\begin{array}{l}\text { a) Sim. } \\
\text { b) Não. }\end{array}$ \\
\hline $\begin{array}{l}\text { C21) Os estudantes recebem respostas rápidas a suas } \\
\text { dúvidas, incentivos e orientação quanto ao progresso } \\
\text { nos estudos? }\end{array}$ & $\begin{array}{l}\text { a) Sim. } \\
\text { b) Não. }\end{array}$ \\
\hline $\begin{array}{l}\text { C22) É assegurada a flexibilidade no atendimento ao } \\
\text { estudante, oferecendo horários ampliados para o } \\
\text { atendimento tutorial? }\end{array}$ & $\begin{array}{l}\text { a) Sim. } \\
\text { b) Não. }\end{array}$ \\
\hline $\begin{array}{l}\text { C23) O curso no Moodle vale-se de diferentes } \\
\text { modalidades comunicacionais para promover a } \\
\text { interação em tempo real entre docentes, tutores } e\end{array}$ & $\begin{array}{l}\text { a) Sim. } \\
\text { b) Não. }\end{array}$ \\
\hline
\end{tabular}




\begin{tabular}{|c|c|}
\hline estudante? & \\
\hline $\begin{array}{l}\text { C24) É facilitada a interação entre estudantes, por meio } \\
\text { de atividades coletivas, presenciais ou via ambiente de } \\
\text { aprendizagem? }\end{array}$ & $\begin{array}{l}\text { a) Sim. } \\
\text { b) Não. }\end{array}$ \\
\hline $\begin{array}{l}\text { C25) O Ambiente Virtual de Aprendizagem incentiva a } \\
\text { comunicação entre colegas? }\end{array}$ & $\begin{array}{l}\text { a) Sim. } \\
\text { b) Não. }\end{array}$ \\
\hline $\begin{array}{l}\text { C26) } \vec{E} \text { assegurado o padrão de qualidade no } \\
\text { atendimento aos estudantes pelos tutores e demais } \\
\text { profissionais do curso? }\end{array}$ & $\begin{array}{l}\text { a) Sim. } \\
\text { b) Não. }\end{array}$ \\
\hline $\begin{array}{l}\text { C27) O material didático é estruturado em linguagem } \\
\text { dialógica, de modo a promover autonomia do estudante } \\
\text { desenvolvendo sua capacidade para aprender e } \\
\text { controlar o próprio desenvolvimento? }\end{array}$ & $\begin{array}{l}\text { a) Sim. } \\
\text { b) Não. }\end{array}$ \\
\hline $\begin{array}{l}\text { C28) A disciplina proporciona aos estudantes construir } \\
\text { o conhecimento? }\end{array}$ & $\begin{array}{l}\text { a) Sim. } \\
\text { b) Não. }\end{array}$ \\
\hline $\begin{array}{l}\text { C29) Você está satisfeito com a aprendizagem } \\
\text { decorrente da disciplina? }\end{array}$ & $\begin{array}{l}\text { a) Sim. } \\
\text { b) Não. }\end{array}$ \\
\hline C30) Você adquiriu algum conhecimento a mais? & $\begin{array}{l}\text { a) Sim. } \\
\text { b) Não. }\end{array}$ \\
\hline $\begin{array}{l}\text { C31) Você acredita que foi válido o investimento feito } \\
\text { em matérias Moodle? }\end{array}$ & $\begin{array}{l}\text { a) Sim. } \\
\text { b) Não. }\end{array}$ \\
\hline $\begin{array}{l}\text { C32) Você acha que o aprendizado por EAD tem boa } \\
\text { qualidade? }\end{array}$ & $\begin{array}{l}\text { a) Sim. } \\
\text { b) Não. }\end{array}$ \\
\hline C33) Vecêfariłąsutra matéria em Moodle? & $\begin{array}{l}\text { a) Simpaliação } \\
\text { b) Não. }\end{array}$ \\
\hline $\begin{array}{l}\text { C34) Que aspectos você destaca como facilitador } \\
\text { nesse processo de ensino-aprendizagiemaçandine (se } \\
\text { possível, cite três)? }\end{array}$ & $\begin{array}{l}\text { a) Sim. } \\
\text { b) Não. }\end{array}$ \\
\hline $\begin{array}{l}\text { C35) Que aspectos você destaca como dificultador } \\
\text { nesse próetşo de ensino-aprendizagem on-line (se } \\
\text { possível, cite três)? }\end{array}$ & $\begin{array}{l}\text { a) } \operatorname{Sim}_{\text {Curso/ }} \\
\text { b) NąQisciplina }\end{array}$ \\
\hline
\end{tabular}

\section{Ambiente/}

Interação

O modelo do questionário incluiu 7 timençã̃o Ambiente do Curso/Interação, Curso/Disciplina, Avaliação e Satisfação, conforme apresentado na Figura 9. Esta última foi objeto de pesquisa do presente estudo. 
Figura 9 - Dimensões propostas na percepção da satisfação da disciplina semipresencial TAPS.

\subsection{ANÁLISE ESTATÍSTICA}

Após a coleta, as respostas foram transpostas para o Excel e posteriormente adequado para o programa estatístico STATA, versão 12.1, por meio dos quais se realizou a análise quantitativa. Primeiramente, foram realizadas análises estatísticas de frequência relacionadas às variáveis sociodemográficas e demais variáveis para todas as sessões do questionário.

Após a análise estatística descritiva, buscou-se explorar os dados do modelo realizando uma análise bivariada dos componentes das diversas dimensões e outras características da população com a variável dependente satisfação (item C29 do questionário). $\mathrm{O}$ teste exato de Fisher foi empregado com o nível de significância de 0,05 .

Em seguida, foi realizada a Regressão Logística Multivariada. O uso de técnicas multivariadas é recomendado quando o objeto de estudo exige eficiência estatística. Entre elas estão regressão múltipla, análise fatorial, análise multivariada de variância, análise discriminante entre outras. Essas técnicas, entretanto, 
possibilitam ao pesquisador testar somente uma relação em uma análise, ou seja: mesmo técnicas que permitem múltiplas variáveis dependentes (análise multivariada de variância e análise canônica) representam apenas uma relação entre variáveis dependentes e independentes. O nível de significância adotado foi de 0,05.

\section{RESULTADOS}

\subsection{PERFIL DOS ALUNOS PARTICIPANTES DA DISCIPLINA TAPS}

No que se refere ao gênero, obteve-se que aproximadamente $74 \%$ dessa população era do sexo feminino (48 participantes) e $26 \%$ do sexo masculino (17 participantes), conforme ilustrado na Figura 10.

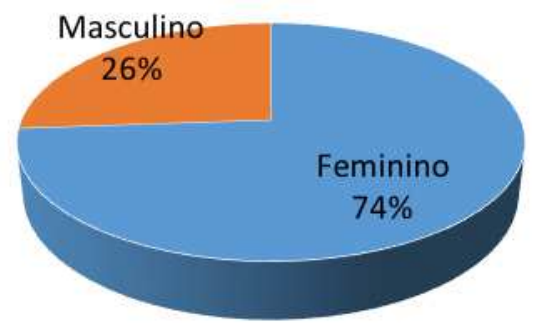

Figura 10 - Gênero dos participantes da pesquisa. 
No que diz respeito à idade dos respondentes, cerca de 58 participantes estão dentro da faixa etária entre 20 e 30 anos, 2 dentro da faixa etária de 31 a 40 anos, 3 dentro da faixa etária entre 41 e 50 anos e 2 com idade superior a 50 anos (Figura 5).

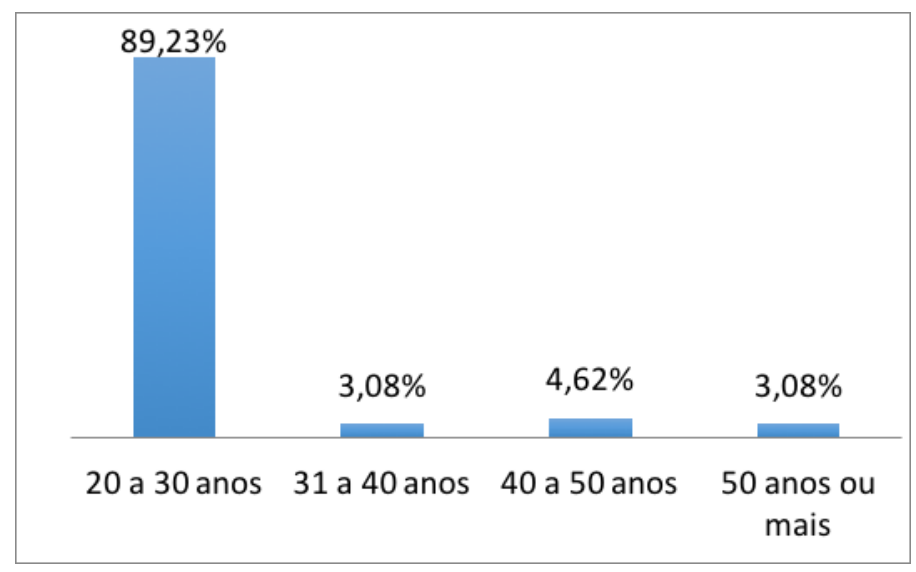

Figura 11 - Gráfico em barras representando a frequência (\%) da faixa etária.

Em relação ao estado civil, os dados obtidos demonstram o seguinte perfil (Figura 4): a maioria dos alunos $(89,23 \%)$ são solteiros, a parcela de casados é de $10,77 \%$, correspondendo, respectivamente, a 58 e 7 alunos.

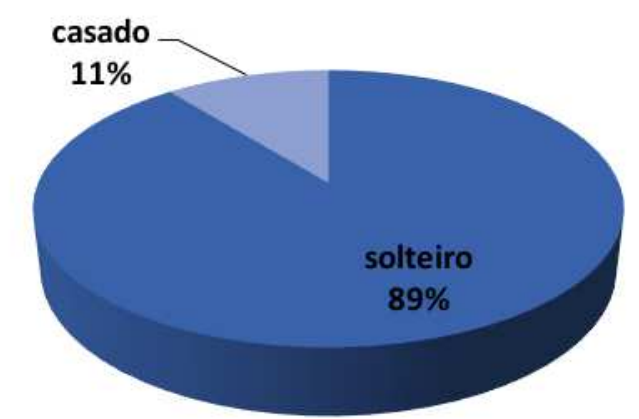

Figura 12 - Frequência (\%) do estado civil dos respondentes.

No que tange à quantidade de filhos, a maior parcela dessa população é solteira. A maioria dos alunos respondentes também não possuíam filhos $(86,15 \%)$. Ainda, cinco alunos possuíam 1 filho e quatro alunos 3 filhos (Figura 7 ). 
Figura 13 - Quantidade de filhos dos respondentes (\%).

Em relação aos cursos da saúde, foram listados os cursos de Ciências farmacêuticas, Educação Física, Nutrição, Gestão em Saúde coletiva, Enfermagem e Terapia Ocupacional. Desses, o curso de Enfermagem foi o que apresentou maior número de alunos inscritos na disciplina TAPS, seguido pelos cursos de Educação Física e Terapia Ocupacional, conforme apresentado na Figura 8.

\footnotetext{
—iências farmacêuticas Educaçã Física

Enfermagem Nutrição

- Saúde coletiva Terapia Ocupacional
}

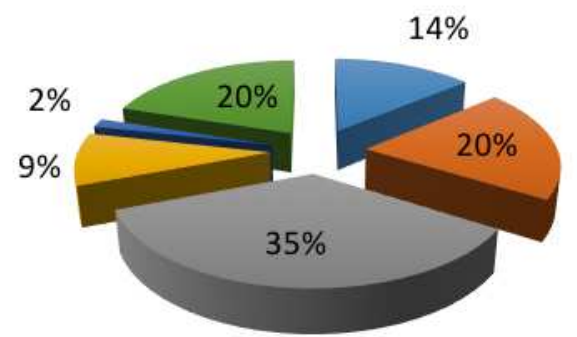

Figura 14 - Frequência (\%) dos cursos da área de saúde dos respondentes.

Ainda em relação ao semestre em que o respondente realizou a disciplina TAPS, observou-se que a maior parte dos alunos estava no oitavo e nono semestre do curso, 32 e $43 \%$, respectivamente (Figura 15). 


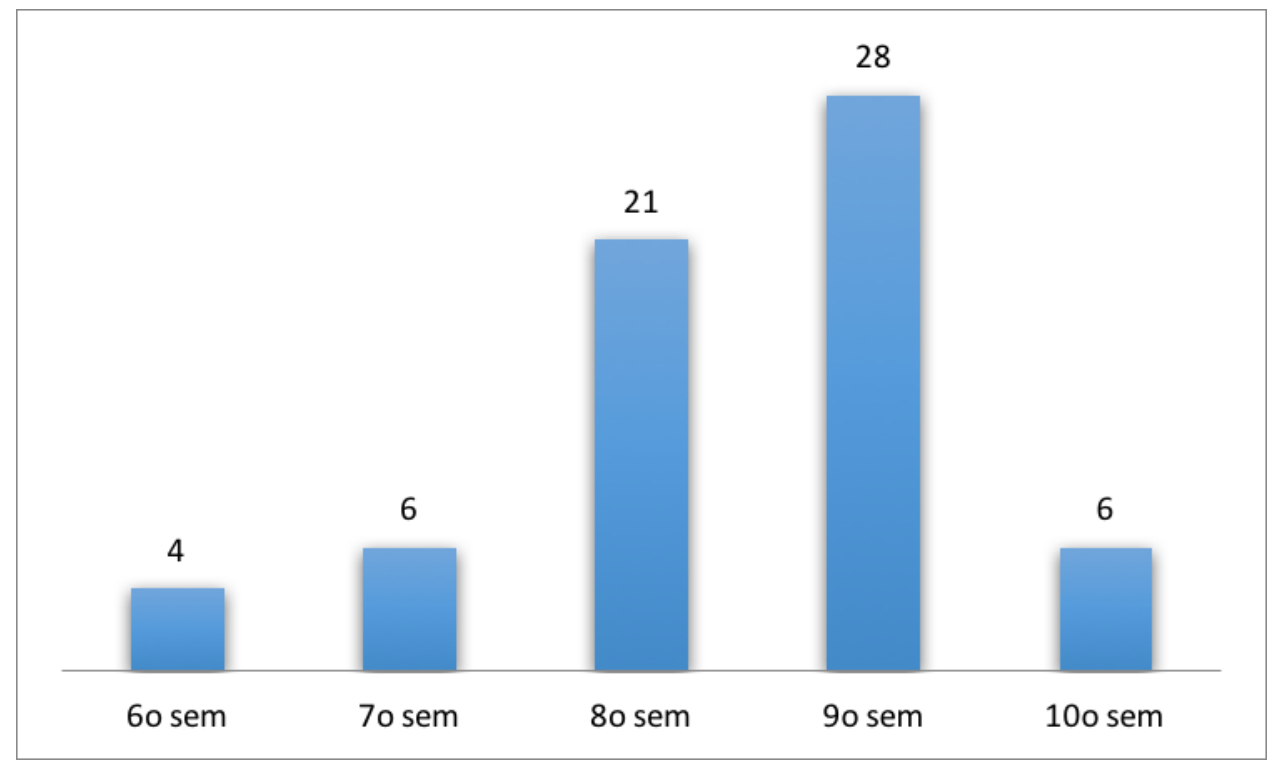

Figura 15 - Gráfico em barras representando a frequência de alunos nos semestres de realização da disciplina TAPS.

No que tange à formação do ensino médio e fundamental dos alunos, a maioria estudou em escolas particulares $(53,85 \%)$, seguida por escola pública $(32,31 \%)$, parcialmente pública $(7,69 \%)$ e parcialmente particular $(6,15 \%)$, o que corresponde a 35, 21, 5 e 4 alunos, respectivamente. Em geral, a localização da escola era central (82\%).

Em relação ao local de acesso prioritário em que o aluno desenvolveu suas atividades acadêmicas no Ambiente Virtual, dos 65 indivíduos, 57 utilizaram como local de acesso a sua residência, representando $87,69 \%$, e apenas $3 \%$ realizaram as atividades acadêmicas no Ambiente Virtual na UnB, conforme demonstrado na Figura 16.

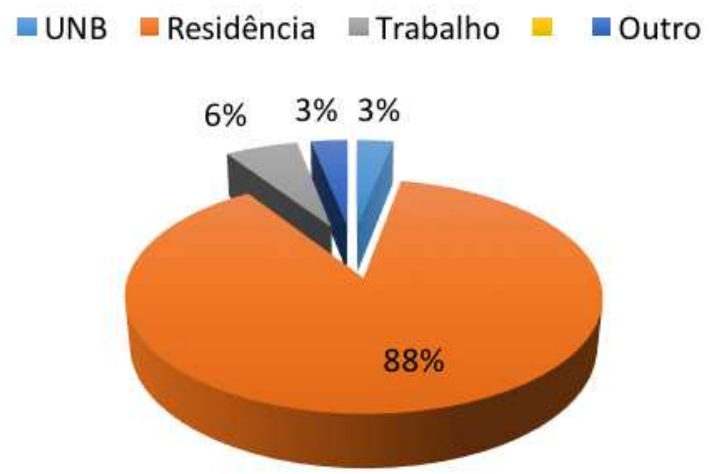

Figura 16 - Frequência (\%) dos locais de estudo dos respondentes. 


\subsection{ANÁLISE DESCRITIVA E ESTATÍSTICA DOS COMPONENTES DA DIMENSÃO ALUNO}

Conforme descrito na sessão dos Métodos, o questionário aplicado continha 3 partes, que incluíram perguntas que avaliavam a satisfação do aluno frente às dimensões Professor, Tutor, Curso, Ambiente do curso/interação, Avaliação, Aluno e Satisfação. Neste tópico, será apresentada a análise descritiva e estatística das perguntas referentes à dimensão Aluno, que compreendem os seguintes itens do questionário: A4, A5, A6, A9, A10, A12. A análise descritiva está apresentada na Tabela 1.

Tabela 1: Análise descritiva da dimensão Aluno.

\begin{tabular}{ll}
\hline \multicolumn{1}{c}{ Itens do questionário } & \multicolumn{1}{c}{ Análise descritiva } \\
\hline A4) Qual sua carga horária de trabalho & a) 8 a 10 horas: $35,38 \%$ \\
semanal? & b) 10 a 20 horas: $20,00 \%$ \\
& c) 21 a 30 horas: $20,00 \%$ \\
& d) 31 a 40 horas: $10,77 \%$ \\
A5) Sua carga horária de trabalho interfere & e) Acima de 41 horas: \\
no rendimento do seu aprendizado? & A) Sim: $35,38 \%$ \\
& b) Não: $27,69 \%$ \\
A6) Quantas horas você dedica & c) Às vezes: $32,31 \%$ \\
semanalmente para leitura do material e & d) Quase nunca: $4,62 \%$ \\
desenvolvimento das atividades? & a) Nenhuma: $1,54 \%$ \\
A9) Qual seu conhecimento em relação à & c) a a 4 horas: $70,77 \%$ \\
utilização do computador? & d) Mais de 8 horas: $1,54 \%$ \\
& b) Pouco: $6,15 \%$ \\
A10) Você possui computador com acesso a & a) Sim: $96,92 \%$ \\
\hline
\end{tabular}


internet em sua residência?

A12) Este curso é o seu primeiro em graduação on-line? b) Não: $3,08 \%$

a) $\operatorname{Sim}: 72,31 \%$

b) Não, já sou formado em uma graduação presencial: $24,62 \%$

c) Não, já sou formado em outra graduação pela EaD:

Para análise da influência dos constructos das dimensões do Aluno na Satisfação do Aluno, a técnica recomendada é regressão logística dos itens que compõem cada dimensão. A fim de compor o modelo multivariado de regressão logística, realizou-se uma análise bivariada dos componentes da dimensão Aluno e outras características da população com a variável dependente satisfação (item C29 do questionário). O teste exato de Fisher foi empregado com o nível de significância de 0,05 . Os resultados estão apresentados na Tabela 2.

Tabela 2: Análise estatística da dimensão Aluno em relação à variável satisfação, utilizando-se o teste exato de Fisher $(\alpha=0,05)$.

\begin{tabular}{l|c}
\hline \multicolumn{1}{c|}{ Itens avaliados na dimensão Aluno } & $\begin{array}{c}\text { Análise estatística (valor de } \\
\text { p) }\end{array}$ \\
\hline $\begin{array}{l}\text { Gênero } \\
\text { Idade }\end{array}$ & 0,722 \\
Estado civil & 0,373 \\
Carga horária de trabalho semanal & 0,758 \\
$\begin{array}{l}\text { Interferência no rendimento do seu } \\
\text { aprendizado }\end{array}$ & 1,0 \\
$\begin{array}{l}\text { Horas dedicadas semanalmente para leitura } \\
\text { do material e desenvolvimento das } \\
\text { atividades }\end{array}$ & 0,619 \\
\hline $\begin{array}{l}\text { Conhecimento em relação à utilização do } \\
\text { computador }\end{array}$ & 1,0 \\
$\begin{array}{l}\text { Posse de computador com acesso a internet } \\
\text { na própria residência }\end{array}$ & 0,120 \\
Primeira graduação on-line? & 1,0 \\
\hline
\end{tabular}

Observa-se que nenhum dos itens avaliados na dimensão Aluno apresentou valores estatisticamente significantes $(p>0,05)$. Dessa forma, as frequências 
observadas para cada item não são diferentes das frequências esperadas, o que determina não existir uma associação significativa entre a variável satisfação e as demais vinculadas à dimensão Aluno.

$\mathrm{Na}$ proposição de um modelo de regressão logística multivariado para a dimensão Aluno, observou-se que o modelo quando incluiu todos os itens apresentou um valor de $p=0,0390$, considerado significativo. Esse modelo determinou um $R^{2}$ de valor 0,5666 , o que significa que o modelo explica aproximadamente $56 \%$ da variável satisfação, ainda que todas elas em separado não tenham sido estatisticamente significativas (Tabela 3 ).

Tabela 3: Regressão logística multivariada da dimensão Aluno na variável satisfação.

\begin{tabular}{cccc}
\hline Variável & OR ajustada & 95\% IC & Valor de $\mathbf{p}$ \\
\hline Gênero & 4.07 & $0.12-137.8$ & 0,434 \\
Estado civil & $6.71 \mathrm{e}-13$ & 0 & 0,996 \\
$\boldsymbol{A 4}$ & 11.69816 & 0.6981283 & 0,087 \\
& & 196.0198 & \\
$\boldsymbol{A 5}$ & 0.8355499 & 0.1588644 & 0,832 \\
& & 4.394589 & \\
$\boldsymbol{A 6}$ & 353.5845 & 0.0244185 & 0,230 \\
& & 5119967 & \\
$\boldsymbol{A 9}$ & 0.0479007 & 0.0007968 & 0,146 \\
$\boldsymbol{A 1 0}$ & 21427.71 & 0.0818676 & 0,117 \\
$\boldsymbol{A 1 2}$ & $5.83 \mathrm{e}+07$ & $5.61 \mathrm{e}+09$ & \\
Modelo & & 0 & 0,998 \\
\hline
\end{tabular}

OD: odds-ratio (razão de chance); IC: intervalo de confiança; $R^{2}=0,5666$

As variáveis idade e filhos não foram computadas no modelo, uma vez que todos os respondentes que se julgaram insatisfeitos com a disciplina estavam na 
faixa etária de 20 a 30 anos e não possuíam filhos. Observa-se que nenhuma das variáveis avaliadas apresentaram valor de $p>0,05$. Entretanto, o modelo foi considerado significativo.

\subsection{ANÁLISE DESCRITIVA E ESTATÍSTICA DOS COMPONENTES DA DIMENSÃO PROFESSOR}

Neste tópico, será apresentada a análise descritiva e estatística das perguntas referentes à dimensão Professor, que compreendem os seguintes itens do questionário de B1 a B8. A análise descritiva está apresentada na Tabela 4.

Tabela 4: Análise descritiva da dimensão Professor.

\begin{tabular}{|c|c|}
\hline Itens do questionário & Análise descritiva (\%) \\
\hline $\begin{array}{l}\text { B1) Os professores demonstram domínio do } \\
\text { conteúdo? }\end{array}$ & Sim: 100 \\
\hline $\begin{array}{l}\text { B2) Os professores esclarecem prontamente } \\
\text { minhas dúvidas? }\end{array}$ & $\begin{array}{l}\text { Sim: } 92,31 \\
\text { Não: } 6,15 \\
\text { Não respondeu: } 1,54\end{array}$ \\
\hline $\begin{array}{l}\text { B3) Os professores são acessíveis fora do } \\
\text { horário do chat ou atividades planejadas on- } \\
\text { line? }\end{array}$ & $\begin{array}{l}\text { Sim: } 80 \\
\text { Não: } 20\end{array}$ \\
\hline $\begin{array}{l}\text { B4) Os professores apresentam os planos } \\
\text { de ensino, elucidando os objetivos das } \\
\text { disciplinas? }\end{array}$ & $\begin{array}{l}\text { Sim: } 95,38 \\
\text { Não: } 4,62\end{array}$ \\
\hline $\begin{array}{l}\text { B5) Os professores são assíduos e } \\
\text { pontuais? }\end{array}$ & $\begin{array}{l}\text { Sim: } 92,31 \\
\text { Não: } 7,69\end{array}$ \\
\hline $\begin{array}{l}\text { B6)Os professores demonstram interesse no } \\
\text { aprendizado dos alunos? }\end{array}$ & $\begin{array}{l}\text { Sim: } 95,38 \\
\text { Não:4,62 }\end{array}$ \\
\hline
\end{tabular}




\section{B7)As explicações dadas pelos professores Sim: 90,77 parecem claras e adequadas? Não:9,23 \\ B8)Os professores relacionam os conteúdos Sim:96,92 trabalhados com a realidade? Não:3,08}

Observa-se que, para a maioria dos itens que avaliaram o componente Professor, se apresentaram valores superiores a 90\% de afirmação. Somente para o item acessibilidade fora do período programado para o chat ou atividades da disciplina foi observado um valor de $80 \%$.

A fim de compor o modelo multivariado de regressão logística, realizou-se uma análise bivariada dos componentes da dimensão Professor com a variável dependente satisfação (item C29 do questionário). O teste exato de Fisher foi empregado com o nível de significância de 0,05. Os resultados estão apresentados na Tabela 5.

Tabela 5: Análise estatística da dimensão professor em relação à variável satisfação, utilizando-se o teste exato de Fisher $(\alpha=0,05)$.

\begin{tabular}{lc}
\hline \multicolumn{1}{c}{ Itens avaliados na dimensão Professor } & $\begin{array}{c}\text { Análise estatística } \\
\text { (valor de p) }\end{array}$ \\
\hline Domínio do conteúdo. & $\begin{array}{c}100 \% \text { de } \\
\text { concordância } \\
1,0\end{array}$ \\
Esclarecimento imediato das dúvidas. & 0,400 \\
\hline $\begin{array}{l}\text { Acessibilidade fora do horário do chat ou atividades } \\
\text { planejadas on-line. }\end{array}$ & 0,824 \\
\hline $\begin{array}{l}\text { Apresentação dos planos de ensino, elucidando os } \\
\text { objetivos das disciplinas. }\end{array}$ & 0,280 \\
\hline Assiduidade e pontualidade. & 0,824 \\
Interesse no aprendizado dos alunos. & 0,672 \\
\hline Explicações claras e adequadas. & \\
\hline
\end{tabular}




\section{Relação dos conteúdos trabalhados com a realidade. $\quad 0,880$}

Observa-se que nenhum dos itens avaliados na dimensão Professor apresentou valores estatisticamente significantes $(p>0,05)$, de forma que as frequências observadas para cada item não são diferentes das frequências esperadas.

No modelo de regressão logística multivariado para a dimensão Professor, observou-se que o modelo, quando inclui todos os itens, apresenta um valor de $p$ $=0,126$, não sendo considerado significativo. Esse modelo determinou um $R^{2}$ de valor 0,0884 , o que significa que o modelo explica aproximadamente $9 \%$ da variável satisfação, ainda que todas elas em separado não tenham sido estatisticamente significativas (Tabela 6).

Tabela 6: Regressão logística multivariada da dimensão Professor na variável satisfação.

\begin{tabular}{cccc}
\hline Variável & OR ajustada & 95\% IC & Valor de $\mathbf{p}$ \\
\hline B5 & 12.33 & $0.61-250.5$ & 0,102 \\
Modelo & & & 0,126
\end{tabular}

OD: odds-ratio (razão de chance); IC: intervalo de confiança; $\mathrm{R}^{2}=0,0884$

As variáveis $\mathrm{B} 2, \mathrm{~B} 3, \mathrm{~B} 4, \mathrm{~B} 6, \mathrm{~B} 7$ e $\mathrm{B} 8$ não foram computadas no modelo, uma vez que todos os respondentes que se julgaram insatisfeitos com a disciplina responderam positivamente esses itens. Ainda, o item B1 não foi considerado no modelo, uma vez que houve $100 \%$ de concordância entre os respondentes. Observa-se que o item B5 apresentou valor de $p>0,05$, não sendo considerado estatisticamente significativo. 


\subsection{ANÁLISE DESCRITIVA E ESTATÍSTICA DOS COMPONENTES DA} DIMENSÃO TUTOR

Neste tópico, será apresentada a análise descritiva e estatística das perguntas referentes à dimensão Tutor, que compreendem os seguintes itens do questionário: B9, C5, C6, C7 e C21. A análise descritiva está apresentada na Tabela 7.

Tabela 7: Análise descritiva da dimensão Tutor.

\begin{tabular}{|c|c|}
\hline Itens do questionário & Análise descritiva (\%) \\
\hline $\begin{array}{l}\text { B9) Existe um alto nível de interatividade } \\
\text { entre professor/ tutor e alunos? }\end{array}$ & $\begin{array}{l}\text { Sim:63,08 } \\
\text { Não:36,92 }\end{array}$ \\
\hline $\begin{array}{l}\text { C5) O modelo de tutoria na disciplina é } \\
\text { adequado? }\end{array}$ & $\begin{array}{l}\text { Sim: } 87,69 \\
\text { Não: } 12,31\end{array}$ \\
\hline $\begin{array}{l}\text { C6) O número de professores/tutor/hora } \\
\text { disponíveis para os atendimentos } \\
\text { requeridos pelos estudantes é adequado? }\end{array}$ & $\begin{array}{l}\text { Sim: } 86,15 \\
\text { Não: } 13,85\end{array}$ \\
\hline $\begin{array}{l}\text { C7) A quantidade de estudantes atendida } \\
\text { pelo tutor é adequada? }\end{array}$ & $\begin{array}{l}\text { Sim: } 90,77 \\
\text { Não: } 9,23\end{array}$ \\
\hline $\begin{array}{l}\text { C21) Os estudantes recebem respostas } \\
\text { rápidas a suas dúvidas e incentivos e } \\
\text { orientação quanto ao progresso nos } \\
\text { estudos? }\end{array}$ & $\begin{array}{l}\text { Sim: } 84,62 \\
\text { Não: } 15,38\end{array}$ \\
\hline $\begin{array}{l}\text { C26) É assegurado o padrão de qualidade no } \\
\text { atendimento aos estudantes pelos tutores e }\end{array}$ & $\begin{array}{l}\text { Sim: } 81,54 \\
\text { Não: } 18,46\end{array}$ \\
\hline
\end{tabular}


demais profissionais do curso?

Na dimensão Tutor, observa-se que somente o item C6, número de alunos por tutor, ficou com margem superior a $90 \%$ de afirmação. O item B9, que avalia a interação entre tutor e alunos, foi o que recebeu os menores valores positivos, e $63 \%$ dos respondentes afirmaram ter um alto nível de interatividade entre esses grupos.

Novamente, realizou-se uma análise bivariada dos componentes da dimensão Tutor com a variável dependente satisfação (item C29 do questionário). O teste exato de Fisher foi empregado com o nível de significância de 0,05. Os resultados estão apresentados na Tabela 8.

Tabela 8: Análise estatística da dimensão Tutor em relação à variável satisfação, utilizando-se o teste exato de Fisher $(\alpha=0,05)$.

\begin{tabular}{lc}
\hline \multicolumn{1}{c}{ Itens avaliados na dimensão Tutor } & $\begin{array}{c}\text { Análise estatística } \\
\text { (valor de p) }\end{array}$ \\
\hline $\begin{array}{l}\text { Alto nível de interatividade entre professor/ tutor e } \\
\text { alunos. }\end{array}$ & 0,473 \\
Modelo de tutoria na disciplina adequado. & 0,583 \\
$\begin{array}{l}\text { Número de professores/hora disponíveis para os } \\
\text { atendimentos requeridos pelos estudantes } \\
\text { adequado. }\end{array}$ & 0,458 \\
$\begin{array}{l}\text { Quantidade de estudantes atendida pelo tutor } \\
\text { adequada. }\end{array}$ & 0,672 \\
$\begin{array}{l}\text { Os estudantes recebem respostas rápidas a suas } \\
\text { dúvidas e incentivos e orientação quanto ao } \\
\text { progresso nos estudos. } \\
\text { Padrão de qualidade no atendimento aos } \\
\text { estudantes pelos tutores e demais profissionais do } \\
\text { curso assegurado. }\end{array}$ & 0,504 \\
\hline
\end{tabular}


Observa-se que nenhuma dos itens avaliados na dimensão Tutor apresentou valores estatisticamente significantes $(p>0,05)$, sendo as frequências observadas semelhantes estatisticamente às frequências esperadas.

No modelo de regressão logística multivariado para a dimensão Tutor, observou-se que o modelo quando inclui todos os itens apresenta um valor de $p=$ 0,4247, não sendo considerado significativo. Esse modelo determinou um $R^{2}$ de valor 0,0639 , o que significa que o modelo explica aproximadamente $6 \%$ da variável satisfação, ainda que todas elas em separado não tenham sido estatisticamente significativas (Tabela 9).

Tabela 9: Regressão logística multivariada da dimensão Tutor na variável satisfação.

\begin{tabular}{cllc}
\hline Variável & OR ajustada & 95\% IC & Valor de $\mathbf{p}$ \\
\hline B9 & 1.63 & $0.18-14.4$ & 0,661 \\
C6 & 5.41 & $0.34-85.6$ & 0,231 \\
Modelo & & & 0,4247 \\
\hline
\end{tabular}

OD: odds-ratio (razão de chance); IC: intervalo de confiança; $\mathrm{R}^{2}=0,0639$

As variáveis C5, C7, C21 e C26 não foram computadas no modelo, uma vez que todos os respondentes que se julgaram insatisfeitos com a disciplina responderam positivamente a esses itens. Observa-se que os itens B9 e C6 apresentaram valor de $p>0.05$, não sendo considerados estatisticamente significativos.

\subsection{ANÁLISE DESCRITIVA E ESTATÍSTICA DOS COMPONENTES DA DIMENSÃO AMBIENTE DO CURSO/INTERAÇÃO}

Neste tópico, será apresentada a análise descritiva e estatística das perguntas referentes à dimensão Ambiente do Curso/Interação, que compreendem os seguintes itens do questionário: C1 a C4; C23 a C25. A análise descritiva está apresentada na Tabela 10. 
Tabela 10: Análise descritiva da dimensão Ambiente do Curso/Interação.

\begin{tabular}{ll}
\hline \multicolumn{1}{c}{ Itens do questionário } & Análise descritiva (\%) \\
\hline $\begin{array}{l}\text { C1) O Ambiente Virtual de aprendizagem } \\
\text { favorece a interatividade entre acadêmicos e } \\
\text { docentes? }\end{array}$ & $\begin{array}{c}\text { Nim: } 47,69 \\
\text { Não: } 52,31\end{array}$ \\
$\begin{array}{ll}\text { C2) O Ambiente Virtual de aprendizagem } \\
\text { favorece a interatividade entre acadêmicos e } \\
\text { tutores? }\end{array}$ & Sim: 81,54 \\
$\begin{array}{l}\text { C3) O Ambiente Virtual de aprendizagem } 18,46 \\
\text { incentiva a comunicação entre colegas? }\end{array}$ & Sim: 61,54 \\
& Não: 38,46 \\
\hline $\begin{array}{l}\text { C4) O Ambiente Virtual de aprendizagem } \\
\text { permite ao estudante resolver, com rapidez, } \\
\text { questôes referentes ao material didático e } \\
\text { seus conteúdos? }\end{array}$ & Não: 18,46 \\
$\begin{array}{l}\text { C23) O curso no Moodle vale-se de } \\
\text { diferentes modalidades comunicacionais } \\
\text { para promover a interação em tempo real } \\
\text { entre docentes, tutores e estudante? }\end{array}$ & Sim: 69,23 \\
$\begin{array}{ll}\text { C24) É facilitada a interação entre } 30,77 \\
\text { estudantes, por meio de atividades } \\
\text { coletivas, presenciais ou via ambiente de } \\
\text { aprendizagem? }\end{array}$ & \\
$\begin{array}{l}\text { C25) O Ambiente Virtual de Aprendizagem } \\
\text { incentiva a comunicação entre colegas? }\end{array}$ & Nim: 84,62 \\
\hline
\end{tabular}

Na dimensão Ambiente do Curso/Interação encontra-se pela primeira vez um item cujo aspecto negativo foi maior que o positivo (item C1). Ainda, nessa dimensão observa-se que todos os itens possuem valores inferiores a $90 \%$ de afirmação, sendo 4 deles inferiores a $70 \%$. Fica evidenciado que os respondentes observam a dificuldade na interação tanto com professor/tutor quanto com os demais colegas, e o Ambiente Virtual não foi um fator decisivo nessa abordagem de ensino à distância.

Em seguida, realizou-se uma análise bivariada dos componentes da dimensão Ambiente do Curso/Interação com a variável dependente satisfação (item C29 do questionário). O teste exato de Fisher foi empregado com o nível de significância de 0,05. Os resultados estão apresentados na Tabela 11.

Tabela 11: Análise estatística da dimensão Ambiente do Curso/Interação em relação à variável satisfação, utilizando-se o teste exato de Fisher $(\alpha=0,05)$, 


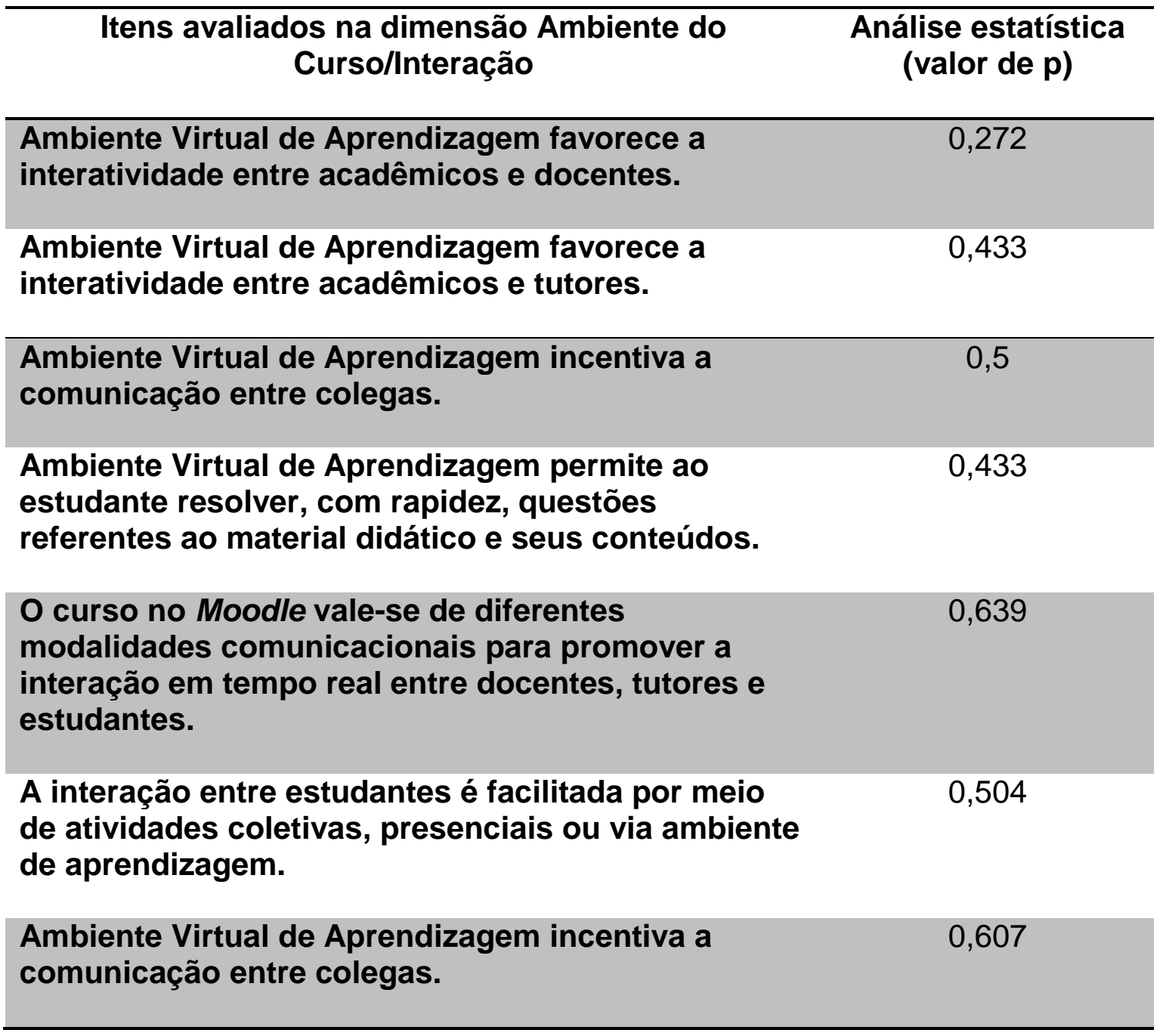

Observa-se que nenhum dos itens avaliados na dimensão Ambiente do Curso/Interação apresentou valores estatisticamente significantes $(p>0,05)$.

No modelo de regressão logística multivariado para a dimensão Ambiente do Curso/Interação, observou-se que o modelo, quando inclui todos os itens, apresenta um valor de $\mathrm{p}=0,8776$, não sendo considerado significativo. Esse modelo determinou um $\mathrm{R}^{2}$ de valor 0,0459, o que significa que o modelo explica aproximadamente $5 \%$ da variável satisfação, ainda que todas elas em separado não tenham sido estatisticamente significativas (Tabela 12).

Tabela 12: Regressão logística multivariada da dimensão Ambiente do Curso/Interação na variável satisfação.

\begin{tabular}{lccc}
\hline Variável & $\begin{array}{c}\text { OR } \\
\text { ajustada }\end{array}$ & $95 \%$ IC & Valor de p \\
\hline
\end{tabular}




\begin{tabular}{cccc}
\hline C1 & 0.53 & $0.04-6.79$ & 0,626 \\
C3 & 0.50 & $0.019-13.7$ & 0,684 \\
C23 & 1.71 & $0.11-25.6$ & 0,696 \\
C25 & 3.54 & $0.27-46.3$ & 0,336 \\
Modelo & & & 0,8776 \\
\hline \multicolumn{2}{r}{ ratio (razão de chance); IC: intervalo de confiança; $\mathrm{R}^{2}=0,0459$}
\end{tabular}

As variáveis C2, C4 e C24 não foram computadas no modelo, uma vez que todos os respondentes que se julgaram insatisfeitos com a disciplina responderam positivamente esses itens. Observa-se que os itens C1, C3, C23 e C25 apresentaram valor de $p>0.05$, não sendo considerados estatisticamente significativos.

\subsection{ANÁLISE DESCRITIVA E ESTATÍSTICA DOS COMPONENTES DA DIMENSÃO CURSO/DISCIPLINA}

Neste tópico, será apresentada a análise descritiva e estatística das perguntas referentes à dimensão Curso/Disciplina, que compreendem os seguintes itens do questionário: C8, C9 C12, C14 a C20, C22, C27 e C28. A análise descritiva está apresentada na Tabela 13.

Tabela 13: Análise descritiva da dimensão Curso/Disciplina.

\begin{tabular}{|c|c|}
\hline Itens do questionário & Análise descritiva (\%) \\
\hline $\begin{array}{l}\text { C8) Os momentos presenciais são } \\
\text { planejados e informados aos estudantes } \\
\text { com antecedência? }\end{array}$ & $\begin{array}{l}\text { Sim: } 92,31 . \\
\text { Não: } 7,69 .\end{array}$ \\
\hline $\begin{array}{l}\text { C9) Os recursos didáticos utilizados na } \\
\text { disciplina são de boa qualidade? }\end{array}$ & $\begin{array}{l}\text { Sim: } 98,46 . \\
\text { Não: } 1,54 .\end{array}$ \\
\hline $\begin{array}{l}\text { C12) No desenvolvimento da disciplina fica } \\
\text { garantida a relação teoria-prática, } \\
\text { respeitadas as especificidades da } \\
\text { disciplina? }\end{array}$ & $\begin{array}{l}\text { Sim: } 72,31 . \\
\text { Não: } 27,69 .\end{array}$ \\
\hline C14) A carga horária é compatível com o & Sim: 95,38. \\
\hline
\end{tabular}




\begin{tabular}{|c|c|}
\hline conteúdo da disciplina? & Não: 4,62 . \\
\hline $\begin{array}{l}\text { C15) Há disponibilidade de tempo para o } \\
\text { estudo e desenvolvimento de atividades } \\
\text { relacionadas à disciplina? }\end{array}$ & $\begin{array}{l}\text { Sim: } 90.77 . \\
\text { Não: } 9,23 .\end{array}$ \\
\hline $\begin{array}{l}\text { C16) Os conteúdos da disciplina estão } \\
\text { relacionados com os conteúdos das demais } \\
\text { disciplinas que compõem o todo da } \\
\text { profissão? }\end{array}$ & $\begin{array}{l}\text { Sim: } 95,38 \\
\text { Não: } 4,62\end{array}$ \\
\hline $\begin{array}{l}\text { C17) O material didático indicado para a } \\
\text { disciplina é de boa qualidade? }\end{array}$ & $\begin{array}{l}\text { Sim: } 95,38 \\
\text { Não: } 4,62\end{array}$ \\
\hline $\begin{array}{l}\text { C18) Há repetição de conteúdos já } \\
\text { abordados em outras disciplinas? }\end{array}$ & $\begin{array}{l}\text { Sim: } 78,46 \\
\text { Não: } 21,54\end{array}$ \\
\hline $\begin{array}{l}\text { C19) O curso oferece atividades de } \\
\text { aplicação prática dos conteúdos estudados? }\end{array}$ & $\begin{array}{l}\text { Sim: } 56,92 \\
\text { Não: } 43,08\end{array}$ \\
\hline $\begin{array}{l}\text { C20) A disciplina proporciona aos } \\
\text { estudantes a oportunidade de desenvolver } \\
\text { projetos compartilhados? }\end{array}$ & $\begin{array}{l}\text { Sim: } 69,23 \\
\text { Não: } 30,77\end{array}$ \\
\hline $\begin{array}{l}\text { C22) É assegurada a flexibilidade no } \\
\text { atendimento ao estudante, oferecendo } \\
\text { horários ampliados para o atendimento } \\
\text { tutorial? }\end{array}$ & $\begin{array}{l}\text { Sim: } 69,23 \\
\text { Não: } 30,77\end{array}$ \\
\hline $\begin{array}{l}\text { C27) O material didático é estruturado em } \\
\text { linguagem dialógica, de modo a promover } \\
\text { autonomia do estudante, desenvolvendo sua } \\
\text { capacidade para aprender e controlar o } \\
\text { próprio desenvolvimento? }\end{array}$ & $\begin{array}{l}\text { Sim: } 92,31 \\
\text { Não: } 6,15 \\
\text { NR: } 1,54\end{array}$ \\
\hline $\begin{array}{l}\text { C28) A disciplina proporciona aos } \\
\text { estudantes construir o conhecimento? }\end{array}$ & $\begin{array}{l}\text { Sim: } 98,46 \\
\text { Não: } 1,54\end{array}$ \\
\hline
\end{tabular}

$\mathrm{Na}$ dimensão Curso/Disciplina, observa-se que a maior parte dos itens ficaram com margem superior a $90 \%$ de afirmação. Entre os itens com margens inferiores se encontram aqueles que fazem referência a uma relação entre teoria e prática e aplicação prática do conhecimento obtido, repetição de conteúdos já vistos em outras disciplinas, flexibilidade no atendimento ao aluno e oportunidade de desenvolver projetos compartilhados.

Realizou-se uma análise bivariada dos componentes da dimensão Curso/Disciplina com a variável dependente satisfação (item C29 do questionário). O teste exato de Fisher foi empregado com o nível de significância de 0,05. Os resultados estão apresentados na Tabela 14.

Tabela 14: Análise estatística da dimensão Curso/Disciplina em relação à variável satisfação, utilizando-se $o$ teste exato de Fisher $(\alpha=0,05)$. 


\begin{tabular}{|c|c|}
\hline & (valor de p) \\
\hline $\begin{array}{l}\text { Momentos presenciais planejados e informados aos } \\
\text { estudantes com antecedência. }\end{array}$ & 0,280 \\
\hline $\begin{array}{l}\text { Recursos didáticos utilizados na disciplina de boa } \\
\text { qualidade. }\end{array}$ & 0,062 \\
\hline $\begin{array}{l}\text { No desenvolvimento da disciplina fica garantida a } \\
\text { relação teoria-prática, respeitadas as especificidades } \\
\text { da disciplina. }\end{array}$ & 0,695 \\
\hline $\begin{array}{l}\text { Carga horária compatível com o conteúdo da } \\
\text { disciplina. }\end{array}$ & 0,176 \\
\hline $\begin{array}{l}\text { Disponibilidade de tempo para o estudo e } \\
\text { desenvolvimento de atividades relacionadas à } \\
\text { disciplina. }\end{array}$ & 0,328 \\
\hline $\begin{array}{l}\text { Conteúdos da disciplina estão relacionados com os } \\
\text { conteúdos das demais disciplinas que compõem o } \\
\text { todo da profissão. }\end{array}$ & 0,824 \\
\hline $\begin{array}{l}\text { Material didático indicado para a disciplina de boa } \\
\text { qualidade. }\end{array}$ & 0,824 \\
\hline $\begin{array}{l}\text { Repetição de conteúdos já abordados em outras } \\
\text { disciplinas. }\end{array}$ & 0,631 \\
\hline $\begin{array}{l}\text { Curso oferece atividades de aplicação prática dos } \\
\text { conteúdos estudados. }\end{array}$ & 0,581 \\
\hline $\begin{array}{l}\text { Disciplina proporciona aos estudantes a } \\
\text { oportunidade de desenvolver projetos } \\
\text { compartilhados. }\end{array}$ & 0,361 \\
\hline $\begin{array}{l}\text { Flexibilidade no atendimento ao estudante, } \\
\text { oferecendo horários ampliados para o atendimento } \\
\text { tutorial. }\end{array}$ & 0,639 \\
\hline $\begin{array}{l}\text { Material didático é estruturado em linguagem } \\
\text { dialógica, de modo a promover autonomia do } \\
\text { estudante, desenvolvendo sua capacidade para } \\
\text { aprender e controlar o próprio desenvolvimento. }\end{array}$ & 1,0 \\
\hline $\begin{array}{l}\text { Disciplina proporciona aos estudantes construir o } \\
\text { conhecimento. }\end{array}$ & 0,938 \\
\hline
\end{tabular}

Observa-se que nenhum dos itens avaliados na dimensão Curso/Disciplina apresentou valores estatisticamente significantes ( $p>0,05)$.

No modelo de regressão logística multivariado para a dimensão Curso/Disciplina, observou-se que o modelo, quando inclui todos os itens, apresenta um valor de $p=0,1742$, não sendo considerado significativo. Esse modelo determinou um $R^{2}$ de valor 0,3879, o que significa que o modelo explica aproximadamente $39 \%$ da variável satisfação, ainda que todas elas em separado não tenham sido estatisticamente significativas (Tabela 15). 
Tabela 15: Regressão logística multivariada da dimensão Curso/Disciplina na variável satisfação.

\begin{tabular}{|c|c|c|c|}
\hline Variável & OR ajustada & $\begin{array}{l}95 \% \\
\text { IC }\end{array}$ & Valor de $p$ \\
\hline$C 12$ & 0.25 & $5-12.3$ & 0,482 \\
\hline C14 & 9.33 & -4.60 & 0,000 \\
\hline C15 & 15.74 & 1097.6 & 0,203 \\
\hline C18 & 3.03 & $3-322.7$ & 0,642 \\
\hline C19 & 1.66 & -84.7 & 0,801 \\
\hline C20 & 1.09 & 84.7 & 0,801 \\
\hline C22 & 1.26 & - 91.8 & 0,915 \\
\hline Modelo & & & 0,1742 \\
\hline
\end{tabular}

OD: odds-ratio (razão de chance); IC: intervalo de confiança * significância estatística; $R^{2}=0,3879$

As variáveis C8, C8, C16, C17 e C27 não foram computadas no modelo, uma vez que todos os respondentes que se julgaram insatisfeitos com a disciplina responderam positivamente esses itens. Ainda, o item C28 não foi considerado no modelo, uma vez que houve $100 \%$ de concordância entre os respondentes. Observa-se que somente o Item C14 (carga horária da disciplina) apresentou significância estatística dentro do modelo.

\subsection{ANÁLISE DESCRITIVA E ESTATIISTICA DOS COMPONENTES DA DIMENSÃO AVALIAÇÃO}

Neste tópico, será apresentada a análise descritiva e estatística das perguntas referentes à dimensão Avaliação, que compreendem os seguintes itens do questionário: B10, C10, C11 e C13. A análise descritiva está apresentada na Tabela 16. 
Tabela 16: Análise descritiva da dimensão Avaliação.

\begin{tabular}{ll}
\hline \multicolumn{1}{c}{ Itens do questionário } & \multicolumn{1}{c}{$\begin{array}{c}\text { Análise descritiva } \\
\text { (\%) }\end{array}$} \\
\hline $\begin{array}{ll}\text { B10) A avaliação (provas, acessos a chats, fóruns, } \\
\text { etc.) serve mais para controlar e classificar o aluno } \\
\text { do que como um processo de correção de rumos e } \\
\text { construção do conhecimento? }\end{array}$ & Não: 41,54 \\
$\begin{array}{ll}\text { C10. Há compatibilidade da avaliação da } \\
\text { aprendizagem com o conteúdo trabalhado? }\end{array}$ & Sim: 98,46 \\
$\begin{array}{l}\text { C11. Há diversidade de instrumentos de avaliação } 1,54 \\
\text { (provas, trabalhos, etc.)? }\end{array}$ & Sim: 67,69 \\
& Não: 32,31 \\
$\begin{array}{l}\text { C13.Os trabalhos de grupo desenvolvidos na } \\
\text { disciplina atingiram os objetivos a que se } \\
\text { propuseram? }\end{array}$ & Sim: 81,54 \\
& Não: 16,92 \\
\end{tabular}

Na dimensão Avaliação, observa-se que somente um item ficou com margem superior a $90 \%$ de afirmação. Entre os itens com margens inferiores se encontram aqueles definem as avaliações como forma de controle e classificação do aluno, diversidade dos métodos de avaliação e do trabalho em grupo.

Realizou-se uma análise bivariada dos componentes da dimensão Avaliação com a variável dependente satisfação (item C29 do questionário). O teste exato de Fisher foi empregado com o nível de significância de 0,05 . Os resultados estão apresentados na Tabela 17.

Tabela 17: Análise estatística da dimensão Avaliação em relação à variável satisfação, utilizando-se o teste exato de Fisher $(\alpha=0,05)$.

\begin{tabular}{lc}
\hline \multicolumn{1}{c}{ Itens avaliados na dimensão Avaliação } & $\begin{array}{c}\text { Análise } \\
\text { estatística } \\
\text { (valor de p) }\end{array}$ \\
\hline $\begin{array}{l}\text { Avaliação (provas, acessos a chats, fóruns, etc.) serviu } \\
\text { mais para controlar e classificar o aluno do que como } \\
\text { um processo de correção de rumos e construção do } \\
\text { conhecimento. }\end{array}$ & 0,555 \\
$\begin{array}{l}\text { Compatibilidade da avaliação da aprendizagem com o } \\
\text { conteúdo trabalhado. }\end{array}$ & 0,062 \\
\hline
\end{tabular}




\section{Diversidade de instrumentos de avaliação (provas, $\quad 0,611$ trabalhos, etc.)? \\ Trabalhos de grupo desenvolvidos na disciplina \\ $0,001^{*}$ atingiram os objetivos a que se propuseram}

\footnotetext{
${ }^{*}$ Diferença estatisticamente significativa $(\mathrm{p}<0,05)$.

Observa-se que o item C13 avaliado na dimensão Avaliação apresentou valores estatisticamente significantes $(p<0,05)$.

No modelo de regressão logística multivariado para a dimensão Avaliação, não foi possível a construção de um modelo, uma vez que para as variáveis C10 e C11 os respondentes que se julgaram insatisfeitos com a disciplina responderam positivamente esses itens, ou seja, os alunos acharam que houve compatibilidade da avaliação de aprendizagem com o conteúdo trabalhado e que houve diversidade dos instrumentos de avaliação. Ainda para as variáveis $\mathrm{B} 10$ e $\mathrm{C} 13$, todos os respondentes insatisfeitos com a disciplina responderam negativamente, ou seja, esses alunos julgaram que as avaliações não serviram como meio de controle e classificar o aluno e não acreditam que os trabalhos em grupos desenvolvidos na disciplina atingiram os objetivos.
}

\subsection{ANÁLISE DESCRITIVA E ESTATÍSTICA DOS COMPONENTES DA DIMENSÃO SATISFAÇÃO}

Neste tópico, será apresentada a análise descritiva e estatística das perguntas referentes à dimensão Satisfação, que compreendem os seguintes itens do questionário: C29 a C33. A análise descritiva está apresentada na Tabela 18.

Tabela 18: Análise descritiva da dimensão Satisfação. 


\begin{tabular}{|c|c|}
\hline Itens do questionário & $\begin{array}{c}\text { Análise descritiva } \\
(\%)\end{array}$ \\
\hline $\begin{array}{l}\text { C29.Você está satisfeito com a aprendizagem } \\
\text { decorrente da disciplina? }\end{array}$ & $\begin{array}{l}\text { Sim: } 93,85 . \\
\text { Não: } 6,15 .\end{array}$ \\
\hline C30.Você adquiriu algum conhecimento a mais? & $\begin{array}{l}\text { Sim: } 89,23 . \\
\text { Não: } 10,77 .\end{array}$ \\
\hline $\begin{array}{l}\text { C31. Você acredita que foi válido o investimento } \\
\text { feito em matérias Moodle? }\end{array}$ & Sim: 100. \\
\hline $\begin{array}{l}\text { C32. Você acha que o aprendizado por EAD tem boa } \\
\text { qualidade? }\end{array}$ & $\begin{array}{l}\text { Sim: } 96,92 . \\
\text { Não: } 3,08 .\end{array}$ \\
\hline C33. Você faria outra matéria em Moodle? & $\begin{array}{l}\text { Sim: } 96,92 \\
\text { Não: } 3,08\end{array}$ \\
\hline
\end{tabular}

Na dimensão Satisfação, observa-se que somente um item ficou com margem inferior a 90\% de afirmação, porém muito próxima a ela. Esse item está relacionado com a aquisição de novos conhecimentos na disciplina TAPS.

Realizou-se uma análise bivariada dos componentes da dimensão Satisfação com a variável dependente satisfação (item C29 do questionário). O teste exato de Fisher foi empregado com o nível de significância de 0,05. Os resultados estão apresentados na Tabela 19.

Tabela 19: Análise estatística da dimensão Satisfação em relação à variável satisfação, utilizando-se o teste exato de Fisher $(\alpha=0,05)$.

\begin{tabular}{lc}
\hline \multicolumn{1}{c}{ Itens avaliados na Dimensão Satisfação } & $\begin{array}{c}\text { Análise estatística } \\
\text { (valor de p) }\end{array}$ \\
\hline C30.Você adquiriu algum conhecimento a mais? & 0,373 \\
C31.Você acredita que foi válido o investimento & $100 \%$ de \\
feito em matérias Moodle? & concordância \\
$\begin{array}{l}\text { C32.Você acha que o aprendizado por EAD tem boa } \\
\text { qualidade? }\end{array}$ & 0,880 \\
C33.Você faria outra matéria em Moodle? & $0,003^{*}$ \\
\hline
\end{tabular}

${ }^{\star}$ Diferença estatisticamente significativa $(p<0,05)$.

Observa-se que o item C33 avaliado na dimensão Satisfação apresentou valores estatisticamente significantes $(p<0,05)$.

No modelo de regressão logística multivariado para a dimensão Satisfação, observou-se que o modelo, quando inclui todos os itens, apresenta um valor de $p=$ 0,1379 , não sendo considerado significativo. Esse modelo determinou um $R^{2}$ de valor 0,1251 , o que significa que o modelo explica aproximadamente $12 \%$ da 
variável satisfação, ainda que todas elas em separado não tenham sido estatisticamente significativas (Tabela 20).

Tabela 20: Regressão logística multivariada da dimensão Satisfação na variável satisfação

\begin{tabular}{cccc}
\hline Variável & $\begin{array}{c}\text { OR } \\
\text { ajustada }\end{array}$ & 95\% IC & Valor de $\mathbf{p}$ \\
\hline C30 & 10.8 & $0.58-200.1$ & 0,110 \\
Modelo & & & 0,1379
\end{tabular}

OD: odds-ratio (razão de chance); IC: intervalo de confiança; $\mathrm{R}^{2}=0,1251$

As variáveis C32 e C33 não foram computadas no modelo, uma vez que todos os respondentes que se julgaram insatisfeitos com a disciplina responderam positivamente esses itens. Ainda, o item C31 não foi considerado no modelo, uma vez que houve $100 \%$ de concordância entre os respondentes. Observa-se que o item C30 apresentou valor de $p>0,05$, não sendo considerado estatisticamente significativo.

\subsection{ASPECTOS FACILITADORES E DIFICULTADORES DO PROCESSO} DE ENSINO-APRENDIZAGEM

Nessa etapa do projeto, visou-se identificar os fatores facilitadores e dificultadores na visão dos alunos da disciplina TAPS. Os respondentes foram encorajados a fornecer três pontos facilitadores e três dificultadores desse processo.

Entre os aspectos facilitadores foram citados: flexibilidade de horário para desenvolver as atividades da disciplina, dinamicidade do ensino, uso da tecnologia, flexibilidade do local para acessar a disciplina, o encontro com a turma inicialmente possibilitando o conhecimento prévio daqueles que farão parte da disciplina, trabalhos em grupo, praticidade, possibilidade em realizar mais cursos simultaneamente e se organizar melhor em relação a outras atividades da universidade, material didático presente no Ambiente Virtual, exposição de opiniões e ideias próprias acerca dos temas abordados, construção do conhecimento crítico, 
interação com matérias diferentes, diversidade dos cursos dos alunos, autonomia para o aluno, organização e comprometimento dos professores e tutores, Ambiente Virtual possui boa organização para a prática do ensino à distância. Desses aspectos facilitadores, o mais citado foi a flexibilidade de horário para realização das atividades da disciplina presente em $45 \%$ das respostas. Ainda a flexibilidade no local de realização dessas atividades e fácil acesso ao material didático/conteúdo da disciplina foram aspectos apontados por cerca de $32 \%$ dessa população.

Entre os aspectos dificultadores apontados estão: flexibilidade de horário para 0 atendimento dos alunos pelos tutores e professores, trabalhar em grupo com pessoas desconhecidas, grande quantidade de alunos, dificuldade na interação com demais alunos, tutores e professores, poucas atividades práticas, empenho do aluno em uma disciplina à distância, pouco comprometimento do aluno com as atividades da disciplina, demora no esclarecimento de dúvidas por parte dos tutores e monitores, discrepância nos critérios avaliativos entre diferentes tutores, falta de compromisso da maioria dos tutores com o processo de ensino-aprendizagem, dificuldade de acesso à internet, curto prazo para entrega dos trabalhos, dificuldade na organização do tempo a fim de realizar as atividades da disciplina, repetição de discussões, métodos de avaliação, outras distrações no computador. Entre os aspectos dificultadores, o mais citado foi a pequena interação entre alunos, docentes e tutores, apontado por cerca de $25 \%$ dos alunos. Em seguida, a flexibilidade de horário para atendimento dos alunos foi apontada por cerca de $18 \%$ dessa população.

\section{DISCUSSÃO}

Este estudo se propôs a encontrar respostas aos questionamentos com o objetivo de avaliar a satisfação dos alunos na disciplina TAPS através dos principais fatores e dimensões que a explicam e, ainda, caracterizar o perfil dos alunos participantes, com a identificação dos aspectos facilitadores e dificultadores. 
O principal objetivo foi avaliar a satisfação dos alunos com a disciplina TAPS e relacionar o grau de satisfação com outras dimensões: Aluno, Professor, Tutor, Ambiente do Curso/Interação, Curso/Disciplina e Avaliação. O grau de satisfação encontrado foi de aproximadamente $94 \%$, o que pode ser considerado alto em relação às disciplinas ministradas de acordo com a filosofia da EaD.

No quesito das perguntas sobre o perfil do aluno participante de TAPS, conforme Figuras de 1 a 4 , o perfil geral dos participantes pertence ao gênero feminino (74\%), o que vai ao encontro do censo da Associação Brasileira de Educação à Distância (ABED), que diz que, entre os alunos que cursam EaD, 54,7\% são do sexo feminino. (MARCUZZO, 2013). A faixa etária de 20 a 30 anos de idade $(89,23 \%)$ foi a mais encontrada, o que demonstra que a maioria dos estudantes de EaD são adultos em idade de alta produtividade, e, com relação ao estado civil, foram encontrados mais solteiros (89\%) e sem filhos (86\%). Como já visto, há uma presença maior do sexo feminino na área da saúde, o que está de acordo com uma pesquisa feita pela Organização para a Cooperação e o Desenvolvimento Econômico - OCDE, em 2012, que teve como resultado uma maior discrepância de gêneros na área de saúde, com apenas $14 \%$ dos homens brasileiros atuando nesse setor, enquanto as mulheres chegam a $32 \%$, o que gera uma média da OCDE de $7,4 \%$ e $19,7 \%$, respectivamente. Os números são do relatório Education at a Glance publicado pela OCDE. (Vasconcelos et all, 2015).

Em relação ao quesito faixa etária, percebe-se que os indivíduos estão na idade de produtividade máxima, de 20 a 30 anos, na qual a maioria deles está na faixa de graduação, justamente após terminar o segundo grau, por volta dos 17 a 19 anos, o que confirma a análise dos dados da PNADs (Pesquisa Nacional por amostra de Domicílios), realizada pelo IBGE (Instituto Brasileiro de Geografia e Estatística), feita em 2009. De acordo com essa pesquisa, cerca de $33 \%$ dos jovens na faixa de idade dos 18 aos 24 anos concluíram o ensino médio, alcançando, assim, os requisitos educacionais necessários para se inserirem no ensino superior. (IBGE, 2009)

Além disso, respondendo ao quesito estado civil e filhos, foi visto que a maioria é de alunos solteiros, com um total de $89 \%$ dos entrevistados, e ainda foi 
observado que $86 \%$ não têm filhos, o que evidencia que a busca pelas melhores oportunidades no mercado de trabalho ocorre antes de se constituir família. Aquillar, 2013, apud Gentili, 2005, afirma que todos podem ter uma condição de emprego favorável, porém o que torna isso concreto é a situação competitiva em que se encontram. O comprometimento com o sustento da família implica uma inserção rápida no mercado de trabalho, tornando inviável a busca por qualificação profissional de qualidade, afastando a possibilidade de competição pelas melhores vagas de emprego. Em relação ao número de filhos, os dados estão em conformidade com a diminuição da quantidade de filhos nas famílias da sociedade brasileira, revelada no Censo 2010 (IBGE, 2010).

Em relação à Figura 5, que corresponde aos cursos de saúde dos que participaram da pesquisa, vê-se que $75 \%$ dos participantes da disciplina pertenciam ao curso de enfermagem (35\%), educação física e terapia ocupacional (20\%, ambos). E os cursos a seguir foram os que tiveram menor participação, sendo Ciências Farmacêuticas com 2\%, seguida por Nutrição com 9\% e Saúde Coletiva com 14\%. Para explicar esses dados, buscaram-se registros da grade curricular de cada curso no sítio eletrônico https://condoc.unb.br/matriculaweb/graduacao/curso campus.aspx, matrícula web da UnB.

No que refere aos cursos que apresentaram menor participação, foi visto pelas suas grades curriculares que apresentavam currículo bastante atarefado em todos os semestres no domínio conexo e, provavelmente, com matérias optativas mais atraentes no tronco comum. Como a matéria TAPS se trata de uma disciplina optativa do tronco comum com valor de 2 créditos, é provável que não seja muito apreciada por alunos desses cursos, o que explicaria o porquê de uma pequena população cursando TAPS, com o objetivo apenas de complementar a carga necessária à conclusão da graduação.

Terapia Ocupacional e Educação Física representaram 40\% dos alunos que cursaram TAPS, $20 \%$ cada uma. A grade curricular de cada uma também apresenta maior quantidade de disciplinas nos primeiros semestres, reduzindo o número de créditos obrigatórios nos últimos. Dessa forma, subentende-se que nos últimos 
semestres os alunos desses cursos optam por essa disciplina também como forma de complementar os créditos necessários. O curso de Enfermagem foi o que apresentou maior número de alunos inscritos alcançando um percentual de $35 \%$. 0 maior interesse dos alunos de enfermagem por essa disciplina pode ser explicado pelo fato de o assunto principal da disciplina ser a promoção da saúde, assunto mais pertinente ao curso de enfermagem, pois este é o que tem o contato mais próximo com o paciente, com participação ativa e constante na promoção da saúde.

Quanto ao semestre mais presente na disciplina, todos os cursos apresentam maior participação de alunos no $8^{\circ}$ e $9^{\circ}$ semestres, o que pode ser explicado pela diminuição de créditos obrigatórios nesses semestres e a necessidade de conclusão dos créditos optativos. Analisando-se a grade curricular, constata-se que o Curso de Ciências Farmacêuticas apresenta uma quantidade de 25 créditos a serem obtidos no $9^{\circ}$ semestre e de 9 créditos no $10^{\circ}$ semestre. No curso de Nutrição, os créditos a serem obtidos são 33 no $7^{0}$ semestre e 17 no $8^{\circ}$ semestre. Como visto, a carga horária é bem apertada, pois somente no $8^{\circ}$ semestre é que se pode cursar outra disciplina optativa, o que gera uma representação de $32,31 \%$ de alunos, que corresponde a 21 alunos no 8ํㅗㄹ semestre. Já em Saúde Coletiva, a grade mostra que no $8^{\circ}$ semestre são 24 créditos e no $9^{\circ}$ semestre são 6 créditos, o que explica 0 porquê de se ter $43,07 \%$ dos alunos nesses semestres, que corresponde a 28 alunos. O curso de Terapia Ocupacional, único que está presente somente na Unidade de Ceilândia da UnB, apresenta tanto no $7^{0}$ quanto no $8^{\circ}$ semestres 22 créditos a serem adquiridos. O curso de Educação Física, licenciatura plena, apresenta no $6^{\circ}$ semestre 14 créditos a serem cursados, no $7^{\circ}$ semestre 8 créditos e no $8^{\circ}$ semestre 6 créditos, o que provavelmente compõe uma parte maciça do universo de $32,31 \%$ no $8^{\circ}$ semestre e de $43,07 \%$ no $9^{\circ}$ semestre. No curso de Enfermagem, que apresenta a maior proporção de alunos cursando TAPS, junto com a grade curricular, foi visto que no $8^{\circ}$ semestre apresenta 10 créditos a serem cursados, no $9^{\circ}$ semestre 28 créditos e no 10ำ semestre 27 créditos, somando aos que estão mais no universo do $8^{\circ}$ semestre composto por 21 alunos, sendo provavelmente a maioria enfermeiros, já que nos semestres seguintes a carga horária é maior. 
No que diz respeito à formação do ensino fundamental e médio, o universo dos alunos que cursaram TAPS, a maioria $53,85 \%$, estudaram em escolas particulares, o que confirma que o estudo público está cada dia mais precário, pois somente $32,31 \%$ são de alunos de instituições públicas. (http://www.brasil.gov.br/educacao/2016/01/metade-das-vagas-em-curso-federaisatende-alunos-de-escolas-publicas acesso 16 fev.2016)

As localizações das escolas que esses alunos estudaram eram centrais. No DF as escolas centrais são consideradas as mais qualificadas e com melhores recursos e professores de ensino. De acordo com o que IOSIF (2007) afirma em seu trabalho, dentro de múltiplos fatores que envolvem a defasagem na qualidade da educação pela escola pública estaria a condição precária das escolas e instalações, juntamente com as condições de trabalho e remuneração dos professores, que contribuem de um modo singular para o comprometimento e piora o quadro de pobreza e desigualdade no Brasil. Ainda diz que no Brasil existem baixos índices de aprendizagem pelas escolas públicas principalmente localizadas nas regiões Norte e Nordeste e nas periferias dos grandes centros urbanos, como Distrito Federal, o que está de acordo com o que foi observado nessa pesquisa de que a maioria dos alunos que cursaram TAPS eram originários de escola pública e concluíram seus estudos, fundamental e médio, em escolas centrais. (IOSIF, 2007)

Em relação ao local de acesso que o aluno utilizou para a aprendizagem da matéria no desenvolvimento de suas atividades acadêmicas, foi observado que a maior proporção foi em domicílios com $88 \%$ das respostas, o que é justificável devido à proposta principal da matéria on-line: Flexibilidade. Sempre se busca encontrar a melhor maneira de apresentar os conteúdos a serem trabalhados, de forma a atender ao princípio da flexibilidade das dimensões espaço e tempo e da diversidade dos aprendizes, para que resulte no aprendizado efetivo do aluno. De acordo com Ferreira, 2007, a EaD traz consigo a facilidade e vantagem de acesso a qualquer momento, hora e local. A EaD tem ganhado cada dia mais flexibilidade, devido às possibilidades recentes que as NTCls, aplicadas à Educação à Distância, proporcionam de interação, através das redes de computadores poderosas em recursos, velocidade, programas e comunicação, que implica a criação de 
programas mais flexíveis e adaptáveis aos alunos, transformando estes em autônomos com o alcance de seu próprio conhecimento. (MORAN, 2007).

A flexibilidade do tempo nos estudos é uma das grandes particularidades da EaD, chamada até de educação flexível. O respeito às características e às necessidades do aluno e a flexibilidade de horário de estudo são aspectos essenciais da EAD, porque a possibilidade de estudar em horários e locais diversos se soma às qualidades desse tipo de educação. Porém, é importante relembrar que a EaD flexibiliza, sim, o tempo e o local da aprendizagem, mas, para o sucesso, é preciso organização do tempo, com o planejamento do que se faz ou será feito com os estudos. Harasin (1990) lembra que a independência no tempo não significa atemporalidade, e sim "flexibilidade" de tempo. Com o uso da EaD, descobriu-se que a flexibilidade se tornou um dos grandes problemas do ambiente de aprendizagem, devido a um descontrole no planejamento de toda essa flexibilidade. Netto et al. (2012) diz que a falta de planejamento para estudar por EaD é um dos motivos de evasão nesse tipo de educação já que alguns alunos apresentam falta de tempo e/ou falta de dedicação necessárias para realizar o curso à distância, levando ao desinteresse e, assim, à evasão. (NETTO et al., 2012)

Conforme a análise descritiva e estatística feita dos componentes da dimensão Aluno e sua satisfação na Tabela 1, observa-se que a maioria dos alunos, $35,38 \%$, trabalhavam de 8 a 10 horas e que $20 \%$ trabalhavam de 10 a 20 horas, 0 que nos leva à correlação de que o trabalho se refere a estágio remunerado ou freelance devido à quantidade de horas trabalhadas. Tal hipótese é reforçada pela faixa etária da maioria, entre 20 a 30 anos. Ainda, 20\% trabalhavam de 21 a 30 horas, os quais fazem parte de um universo que provavelmente trabalha de 4 a 6 horas diárias, podendo existir ainda alunos de estágios ou alunos que trabalham regularmente registrados. E 10,77\% trabalhavam de 31 a 40 horas e acima de 41 horas são $13,85 \%$. É bem provável que estes sejam alunos com mais idade, talvez cursando uma segunda graduação. Devem ter filhos e serem casados. Muitos devem fazer parte do universo de idade de 40 a 50 anos, ou mais, casados que correspondem a $11 \%$ dos entrevistados, e ainda dos que são pais somando $14 \%$. 
A pergunta A5 avaliou se a carga horária de trabalho interfere no aprendizado desse aluno. Como esperado, a maioria respondeu que sim, 35\%, 38\% concordando com o que foi explicado anteriormente que o aluno de $\mathrm{EaD}$ tem que ter domínio sobre o seu tempo e sobre suas vontades, sempre reservando um momento de estudos diários. Ainda 27,69\% responderam que não, 32,31\% responderam que às vezes, e 4,62\% quase nunca. Pacheco, 2010, através da análise dos fatores dificultadores da aprendizagem dos alunos à distância, em seu trabalho, afirma que uma das dificuldades mais apontadas pelos estudantes foi justamente a carga horária semanal de trabalho, a qual $53,42 \%$ dos estudantes afirmaram ser um fator que dificulta os estudos, pois, por falta de tempo, deixam de se dedicar aos estudos.

A pergunta A6 está relacionada a quantas horas semanalmente o aluno dedica aos seus estudos: 1,54\% diz que nenhuma, 70,77\% diz que de 2 a 4 horas semanalmente, o que é o indicado para a aprendizagem nesse tipo de estudo para que ocorra o aprendizado, levando à satisfação presente nesse universo. E os que responderam de 4 horas a 6 horas foram 26,15\%. Ainda 1,54\% disse que mais de 8 horas. O que se nota é que muitos alunos esbarram na falta de tempo e/ou na falta de dedicação necessárias para realizar o curso à distância, o que prejudica a sua aprendizagem e leva a uma necessidade de atenção maior por parte do professor e tutor durante o curso. (NETTO et al., 2012). A organização do tempo para os estudos é necessária para que o processo de ensino-aprendizagem aconteça, resultando em um conjunto de conhecimentos adquirido por meio do seu interesse e dedicação. Havendo o comprometimento com as atividades, participação, frequência e avaliação, o ensino pela EaD é tão eficaz e de qualidade quanto o ensino presencial. (NETTO et al., 2012)

Associando os dados da Figura 6 com a Tabela 1, itens A4, A5 e A6, nota-se uma semelhança entre as distribuições de frequência relativa. Ainda, $20 \%$ dos alunos que participaram da disciplina pertencem ao curso de Educação Física e Terapia Ocupacional, totalizando $40 \%$, e os alunos que trabalham de 10 a 20 horas correspondem a $20 \%$, e outros $20 \%$ trabalham de 21 a 30 horas semanais. Ainda, $10,77 \%$ trabalham de 31 a 40 horas e $13,85 \%$ acima de 40 horas semanais, onde estão inseridos os $1,54 \%$ da pergunta $A 6$, interferindo diretamente na satisfação com a EaD. Portanto, pode-se concluir que as distribuições da Figura 5 correspondem às 
distribuições do item A4 da Tabela 1. Gaspareto, 2012, afirma que, para o aluno de EaD, é necessário e indispensável 2 a 4 horas de estudos, pois o reflexo disso é a interferência no desenvolvimento das atividades e da aprendizagem da EaD, tendo como resultado a satisfação do aluno.

Ainda na Tabela 1, as perguntas A9, A10 e A11 também caminham juntas. Vê-se que todos os alunos têm algum conhecimento em relação à utilização do computador, alguns com pouco domínio 6,14\%, outros com domínio considerado Bom, 52,31\%, e ainda outros com ótimo domínio, 41,54\%. Essas proporções de conhecimento sobre a principal ferramenta utilizada na $\mathrm{EaD}$ já eram esperadas, uma vez que é indispensável que o aluno de EaD saiba utilizar o computador, pois se o aluno não souber, o curso estará descaracterizado. Barros, 2013 afirma que existe a real necessidade de se alcançar uma sociedade cada vez mais conectada sabendo utilizar um computador. Se assim não for, acarretará em consequências como a não obtenção de aprendizado satisfatório do curso.

No item A10, percebe-se que $96,92 \%$ têm computador com a acesso à internet em seu domicílio. Segundo Neri, 2012, a inclusão social está diretamente ligada com os lugares de acesso. E, de acordo com Hickel, 2011, a EaD é, sem dúvida, uma forma de promover a inclusão social em todos os sentidos. Entretanto, apesar desta grande maioria, vimos que 3,08\% não possuem computador e internet em seu domicílio, provavelmente relacionado ao nível socioeconômico. Ainda mostra que, mesmo assim, é possível cursar uma disciplina em EaD sem ter computador, devido à estrutura que a Universidade tem e oferece aos alunos. No item A12, $72,31 \%$ responderam que essa seria a sua primeira graduação on-line, $24,62 \%$ disseram que tinham uma formação por graduação presencial, e outros 3,08\% afirmaram que já têm cursado graduação por EaD. Nesse item houve um erro da pesquisadora em elaborar a pergunta. A pergunta a ser feita era se o aluno já tinha feito cursos à distância e não graduação à distância. $O$ erro não pôde ser corrigido, pois o questionário já havia sido aplicado e não existia mais tempo hábil para refazêlo. Se fossemos considerar que eles estavam respondendo em relação a cursos e não graduações, então, para a maioria, esse foi o primeiro curso à distância, reforçando a tese de que a EaD só serviria para os menos afortunados e que seria um tipo de estudo de baixa qualidade, isso em pleno século XXI. O que também 
confirma novamente o que Hickel, 2011, citou: "para muitas pessoas, a modalidade de ensino Educação a Distância (EAD) é uma 'educação de segunda linha', 'mais fácil', 'mais barata', 'menos trabalhosa'”.

Em 2010, foi feito, através do Enade, um levantamento com a aplicação do exame nacional aos alunos de graduação que estavam realizando curso à distância. Foi comparado o desempenho dos alunos dos mesmos cursos nas modalidades à distância e presencial. Foi constatado que, em 7 de 13 áreas, os alunos do curso à distância superam os alunos do ensino presencial, e ainda os alunos que estavam no início do curso se saíram melhor em 9 áreas. Isso comprova que, se o aluno cumprir todos os requisitos durante o curso, ele irá adquirir aprendizagem através da EaD, melhorando assim o seu conhecimento e sua mão de obra. (NUNES, 1993)

$\mathrm{Na}$ Tabela 2, foi apresentada a análise estatística bivariada que não indicou diferença estatística entre as variáveis independentes e a variável satisfação. No entanto, na proposição de um modelo de regressão logística multivariado para a dimensão aluno, Tabela 3, observou-se que quando incluído todos os itens dessa dimensão, foi encontrado um modelo estatisticamente significativo, que explica $56 \%$ da variável satisfação. Dessa forma, os constructos que formam a Dimensão aluno foram os mais importantes na determinação do grau de satisfação dos alunos que cursaram TAPS, o único a obter um modelo estatisticamente significativo, respondendo assim que o constructo aluno é o responsável principal pela própria satisfação com a EaD. Não existe distinção de gêneros, estado civil, idade e conhecimento de informática que corroboram mais do que a dimensão aluno com o aspecto democrático da EaD. As variáveis idade e filhos não foram aqui computadas pois os que se julgaram insatisfeitos com a disciplina à distância se encontravam na faixa etária de 20 a 30 anos e não possuíam filhos.

$\mathrm{Na}$ análise descritiva e estatística dos componentes da dimensão Professor, representada na Tabela 4, o item B1 mostra que existe unanimidade em relação ao professor ter domínio do conteúdo, uma vez que $100 \%$ dos alunos responderam sim. Isso está de acordo com o Machado, 2004, que diz em seu artigo que é preciso ter uma excelente formação acadêmica e pessoal, gerando capacidade intelectual e domínio da matéria com profundidade. 
No item B2, foi questionado se os professores esclareceram prontamente as dúvidas dos alunos, e 92,31\% disseram sim, 6,15\% disseram não, e ainda houve $1,54 \%$ que não responderam esta questão, o que está de acordo com a proposta de aprendizagem da EaD, e também com o que Machado diz sobre a obrigatoriedade da formação do professor ser de excelência. Ainda no item B3, foi questionado se os professores são acessíveis fora do horário estipulado. $80 \%$ disseram sim, e 20\% não. Nesse item, pode-se entender que a Educação on-line deve ser flexível a todos, até mesmo ao professor. Na matéria TAPS existe exigência de que o professor, ou tutor, tem a obrigação de sempre responder os questionamentos e dúvidas em até 48 horas após a postagem do aluno. Sendo assim, o aluno não fica sem direcionamento ou resposta durante todo o decorrer do curso. Não há prejuízo de aprendizagem nesse período, assim não existe a real necessidade de o professor responder imediatamente. Isso não descaracteriza a proposta da EaD e não deveria ser um indicativo de insatisfação com a disciplina.

O uso de AVA levou a uma redefinição do papel do professor acrescendo novas obrigações e diminuindo a exigência de seu papel tão presente. Agora deve utilizar as NTCls juntamente com seus alunos compartilhando ideias e propostas, assumindo o papel de ir junto com o aluno, navegando juntos sem dar a respostas prontas aos questionamentos, mas sempre indicando a direção para se chegar aos pontos finais dos questionamentos. Professor deve levar os alunos a descobrir novos caminhos para o conhecimento, sempre apontando as direções corretas para as possibilidades apresentadas, abrindo novos caminhos para construção do saber, por meio da escrita, da leitura, do pensamento do outro e ainda do desenvolvimento de projetos colaborativos com o grupo de alunos.

O professor de EaD passa a ter novas responsabilidades bem diferentes do ensino presencial, transpondo as exigências de sala convencional. Tem como exigência saber manusear muito bem as novas tecnologias de informação que trazem as diversas possibilidades de uso. O professor necessita dominar o conteúdo ofertado com competência suficiente transformando-se em um agente mediador do conhecimento, apresentando raciocínio lógico estratégico nas intervenções de tarefas pedagógicas e incentivando os alunos na busca por distintas fontes de informações, levando ao aperfeiçoamento no processo. Deve prever todo tipo de desvio, antes mesmo de o problema ser identificado. (Almeida, 2011) 
Então existem características do bom professor e do tutor de $\mathrm{EaD}$, conforme Machado, 2004: Pontualidade, de acordo com o que foi acordado com os alunos, estar sempre pronto a atender. Seja dar interações do aluno, responder um questionamento via fórum de discussões, dar um feedback a uma resposta de exercício, cobrar o envio de um trabalho, ou de uma dúvida geral. Pois se o aluno faz um questionamento e a resposta demora a chegar isso leva a desmotivação e aborrecimento, podendo ser pontual ou em relação a totalidade do curso. Se for frequente o sentimento pode ser repassado ao curso como um todo, levando a problemas que desacreditam no processo de ensino-aprendizagem que podem desperdiçar muitos recursos e tempo, o resultado será a insatisfação do aluno com a $\mathrm{EaD}$ como um todo; Comprometimento, diretamente relacionado à pontualidade e à capacidade do professor em cumprir e responder de acordo com o que foi combinado e aos questionamentos que vão surgindo. Iniciativa, quando o professor tem a capacidade de apoiar o aluno em novas ações, novos projetos no Ambiente Virtual. Tais ações incentivadoras podem ser: participação mais efetiva em um fórum, realizar um trabalho. Essas características podem se tornar mais fácil de acordo com o apoio por meio das NTICs, a partir da aplicação de sensores que identificam as mudanças e respostas na plataforma avisando os professores.

Apesar desta posição tão marcante do professor nas definições das funções da $\mathrm{EaD}$, alguns alunos declararam a falta da presença física do professor, falta de interação, levando a um paradoxo que deve ser focado em uma outra futura pesquisa, que deve procurar saber como se melhorar a interatividade entre professor e aluno e entre todos os componentes do grupo.

B4 questiona se os professores apresentam o plano de ensino mostrando os objetivos da disciplina. 95,38\% responderam que sim contra 4,62\% que não. Esse contato inicial é importante, pois é quando se explica o que deverá ser aprendido durante o curso, para que os alunos tenham conhecimento do que esperar, concordando com o que Palloff (2002) diz, que deve ser apresentado um plano de ensino no começo do curso para que os participantes possam comentar e debater sobre suas expectativas em relação ao curso. Já no item B5, pergunta-se se os professores são assíduos e pontuais. 92,31\% responderam que sim, 7,69\% que não, e no B6, a pergunta foi se os professores demonstravam interesse no aprendizado dos alunos onde $95,38 \%$ disseram que sim e $4,62 \%$ não. Assiduidade, pontualidade 
e o interesse no aluno são consequências de outro atributo, o compromisso. Esses atributos são indispensáveis a um bom profissional, e esses valores concordam com o que Mercado, 2008, que essas características são aspectos inerentes ao profissionalismo do professor que juntas corroboram para a satisfação do aluno com a disciplina, pois o mesmo vê um compromisso contínuo de seu professor em conceder um aprendizado de qualidade elevando assim o nível do ensino que o motiva a ser compromissado com as atividades propostas.

Ainda, Mauri Collins e Zane Berge, 1996, apud Palloff, 2002, classificou as várias tarefas e papéis exigidos do professor on-line em quatro áreas, que serão citadas brevemente a seguir: pedagógica, gerencial, técnica e social.

Função pedagógica - diz que o professor se torna um facilitador levando o ambiente on-line a ser amigável para todos o que é essencial para que se aconteça a aprendizagem on-line. $O$ papel do professor sempre será 0 de garantir que 0 processo educativo ocorra entre os alunos em qualquer ambiente educacional.

Função gerencial - O professor fica responsável por enviar, com antecedência, um plano de ensino com as tarefas a serem realizadas e as diretrizes iniciais, levando os alunos a gerarem seus próprios questionamentos, para se realizar discussões e adaptações. O plano de ensino deve envolver normas referentes ao agendamento do curso, ao seu ritmo, aos objetivos traçados, à elaboração de regras e à tomada de decisões. O professor de um curso on-line é também seu administrador. (PALLOFF, 2002)

Função técnica - Importante que o professor tenha domínio técnico da tecnologia utilizada, sendo capaz de transmitir tal domínio aos seus alunos, atuando como facilitador do curso. Além disso, deverá existir um suporte técnico ininterrupto disponível para todos os componentes do curso, de modo que, mesmo que o professor seja menos proficiente com a tecnologia possa ministrar um curso on-line.

Função social - O professor é o responsável por facilitar e dar espaço aos aspectos pessoais e sociais da comunidade on-line sendo um facilitador educacional. Collins e Berge,1996, apud Palloff, 2002, definem essa função por meio de elementos essenciais para se construir e manter a comunidade virtual como "estímulo às relações humanas, com a afirmação e o reconhecimento da contribuição dos alunos; isso inclui manter o grupo unido, ajudar de diferentes 
formas os participantes a trabalharem juntos por uma causa comum e oferecer aos alunos a possibilidade de desenvolver sua compreensão da coesão do grupo".

$\mathrm{Na}$ disciplina TAPS, tem-se o tópico Cafezinho onde os componentes da disciplina em EaD tem a oportunidade de trocar informações inerentes a todos os assuntos com a ideia de criar-se laços, concordando com o Palloff (2002) que têm o hábito de criar um espaço comunitário no site dos seus cursos para que todos, professores e alunos, possam relaxar e conversar. Um ambiente independentemente do restante e sagrado, cuja finalidade é que os participantes se conheçam melhor e o trabalho em grupo seja mais confortável, sempre levando em consideração o elemento humano para que se tenha uma interação eletrônica de qualidade. Neste momento, acontece compartilhamento da vida de cada um, sobre viagens feitas ou sonhos e emoções mantendo a conexão mútua. Palloff, diz que isso é essencial para o grupo on-line, onde se desenvolve uma atitude de confiança, fundamental para a qualidade da aprendizagem na sala de aula on-line.

Ainda sobre as funções de professor de EaD, Gutiérrez e Prieto (1994) o nomearam de "assessor pedagógico" promovendo reuniões em grupos e avaliar todos. Afirmando que a sua função é a de fazer a ligação entre a instituição e o aluno sempre acompanhando o processo para enriquecê-lo com seus conhecimentos e experiências. Tendo como características: ser capaz de uma boa comunicação; possuir uma clara concepção de aprendizagem; dominar bem o conteúdo; levar a reflexão; facilitar a construção de conhecimentos; intercâmbio de experiências e informações; estabelecer relações empáticas com o aluno; buscar as filosofias como uma base para seu ato de educar; e constituir uma forte instância de personalização. (Gutiérrez e Prieto, 1994).

Para Arnaldo Niskier (1999), o professor de EaD deve reunir as qualidades de um planejador, pedagogo, comunicador, e técnico de Informática. Participando na produção dos materiais, selecionando os meios mais adequados para sua multiplicação, e mantendo uma avaliação permanente a fim de aperfeiçoar o próprio sistema, prevendo as possíveis dificuldades, buscando se antecipar aos alunos na sua solução. O mesmo merecer ser valorizado, pois com toda essa responsabilidade, ainda consegue atingir o maior número de alunos, torna-o mais vulnerável a críticas e a contestações. 
As explicações dos professores parecem ser claras e adequadas, uma vez que $90,77 \%$ responderam que sim, e 9,23 que não. Duarte, 2011, diz que a função do professor em EaD não é uma tarefa fácil e sim bastante complexa, em construção permanente. Portanto espera-se que ele possua uma visão clara e adequada da construção de conhecimentos como um processo dinâmico dos conteúdos e processos adequados de avaliação, passando de tal forma ao aluno, estimulando a construção do conhecimento necessário à manutenção da qualidade do curso precedida por satisfação do aluno.

E na B8 é questionado se os professores relacionam os conteúdos trabalhados com a realidade. Esse construto pode estar relacionado ao quesito satisfação, porque quando o professor apresenta um conteúdo de acordo com a realidade, leva o aluno a integração dos conceitos apresentado paralelo a realidade vivenciada onde o mesmo terá novos questionamentos. (FAGUNDES, 1999 apud SANTOS, 2009)

Holmberg (1985) apud Bartolome (1998) considera como uma estratégia importante para desenvolver a autonomia dos estudantes, a disponibilidade de várias atividades, onde o próprio aluno seleciona as que gostaria de fazer aproximando a realidade ao aprendizado, isso está sendo desenvolvido na Universidade de Twente, Holanda, pela Profa. Collis. Existem pesquisas sobre aprendizagem dos adultos que mostram que os alunos têm uma aprendizagem mais significativa quando utilizamos situações da vida real e de suas experiências de vida. (BARTOLOMÈ, 1998). Então sendo assim para que se adquira uma aprendizagem eficaz é aconselhado se utilizar atividades que se aproximem da realidade dos alunos, como por exemplo exercícios de simulação on-line, explorando todas as possibilidades possíveis na EaD através da NTICs.

A fim de explicar o modelo multivariado de regressão logística dos itens avaliados na dimensão professor correlacionado com a variação satisfação, utilizamos novamente o teste de Fisher com nível de significância 0,05 , representado na Tabela 5, onde nenhum dos itens apresentou valor significativo. Ainda no modelo de regressão logística multivariado para essa dimensão foi observado que determinou um $R^{2}$ de 0.0884 , levando a encontrarmos aqui a variável satisfação com um valor de $9 \%$, dizendo que esses itens separados não têm valor significativo. 
$\mathrm{Na}$ Tabela 6, regressão logística multivariada da dimensão Professor na variável satisfação, somente com o item B5, o modelo não foi considerado significativo, vendo que o valor $\mathrm{p}$ foi de 0,102, mostrando que esses itens não interferem na variável satisfação do aluno com o professor de $\mathrm{EaD}$, não existindo distinção estatisticamente significativa entre elas. As demais variáveis não fizeram parte devido que os que se encontravam insatisfeitos responderam de forma positiva a esses itens e a B1 em especial teve $100 \%$ de concordância.

A análise descritiva e estatística dos componentes da dimensão Tutor, representada na Tabela 7 , na B9, questionou-se se existiu alto nível de interatividade entre professor/ tutor e aluno, já que 63,08\% disseram sim, contra $36,92 \%$ que responderam não. Aqui encontramos uma dificuldade para que o aprendizado através da EaD aconteça. Justamente por ser um tipo de ensino não presencial é indispensável que exista uma alta interatividade entre os componentes do curso, se assim não for leva a insatisfação seguida de evasão do curso. Melo, 2009 cita em seu artigo Barbero, 2005 que destaca o importante papel da interatividade no processo de construção do conhecimento, em que o professor deixa de ser simplesmente um divulgador de conteúdo e passa a ser responsável pela construção de reflexões e questões mais complexas junto a seus alunos levando a satisfação, pois o mesmo se sente parte do desenvolvimento de qualidade do aprendizado. (MELO, 2009, apud Martin-Barbero, 2005)

$\mathrm{Na}$ C5 é questionado se o modelo de tutoria é adequado, e 87,69\% responderam que sim, e 12,31\% que não. A partir do século XIX, o tutor passou a fazer parte da composição do quadro docente assumindo no campo acadêmico a função de assessorar os alunos, de modo individualizado, cuidando de seu comportamento e de seus estudos sob a coordenação do professor titular. (PRETI, 2011). Com o uso das NTCls na EaD podemos ver a possibilidade indispensável de o tutor participar de todas as etapas do curso, através das combinações de tecnologias convencionais e modernas, proporcionam, ao aluno, a possibilidade de estudar individualmente ou em grupo, em ambientes diversos, através de métodos de orientação e tutoria presencial ou à distância. O modelo de tutoria é indispensável, mesmo se tratando de uma autoaprendizagem, pois o tutor tem função sempre dar um feedback ao aluno, o mesmo precisa também se dedicar sendo responsável e envolvido com o desenvolvimento de todas as atividades 
propostas. (TOZZI, 2001). Yacef (2002) reforça o papel do tutor e a necessidade de incluir um modelo e uma interface própria na plataforma para ele, apoiado por ferramentas de monitoramento e análise das informações dando incentivo aos grupos de estudos formados e as atividades de integração.

O tutor está ligado diretamente as responsabilidades de incentivar, motivar e dar feedback ao aluno mais breve possível, sendo um elemento chave para a aprendizagem, trazendo um trabalho satisfatório ao curso e aos alunos sendo um dos agentes do processo ensino-aprendizagem em EaD utilizando um ambiente interativo. A motivação e o comprometimento de todos os envolvidos no processo ensino-aprendizagem são fundamentais para que essa interação ocorra. A distância física entre alunos e tutor cria a necessidade de uma infraestrutura que permita interação entre os mesmos pois a ausência de tutores seja presencial ou on-line não gera interação o que causa grandes danos levando a evasão do curso. Sendo assim o tutor tem grande importância, pois ele atua junto ao aluno orientando-o para que ele desenvolva o seu próprio aprendizado, adquira autonomia de estudo e de práticas.

Segundo Aretio (2001), o tutor de EaD tem suas funções que vão além da mediação entre aluno e professor, ele é o principal responsável pela motivação do aluno nesse tipo de ensino. Atender o aluno com flexibilidade de horários, lugares distintos e meios diversos é basicamente o papel do tutor, que deve ter uma série de habilidades e competências tecnológicas, sociais e profissionais, para responder aos questionamentos. Para Dalmau (2007), o tutor se torna a pessoa chave no curso, indispensável para o aprendizado e tem a preocupação de tornar o seu estudo mais agradável, completo, e próximo do aluno. Devido ao seu contato constante com os alunos, os tutores observam os problemas que ocorrem quanto à compreensão dos textos, atividades e dificuldades quanto prazos e utilização de ferramentas, muito além do que o professor consegue acompanhar.

$\mathrm{Na}$ C6, o número de professor/tutor por hora disponível para os atendimentos requeridos é adequado para o estudante, $86,15 \%$ sim e 13,85 não. $E$ na $C 7$ se é a quantidade de estudantes atendida pelo tutor é adequada, onde 90,77\% responderão que sim e 9,23\% que não. De acordo com o Neder, 1999 estipulou-se que a relação ideal seria de 1 tutor para cada 20 a 30 alunos, não podendo se 
ultrapassar essa quantidade, o que colocaria em risco a qualidade do curso uma vez que 0 atendimento individual é o principal critério que permite uma interação de qualidade entre os componentes, respeitando as diferenças que o ensino à distância traz, como a diversidade de expectativas dos alunos.

Na disciplina TAPS, tinha-se 1 professor para 200 alunos, 1 tutor para cada 20 alunos e 1 monitor para cada 10 alunos. Os professores e os tutores afirmam ter horário disponível on-line para os estudantes desde que se tenha demanda e, ainda assim, entende-se que os tutores têm mais horários de atendimento, já que o também cumpre a função de mediador da relação entre aluno e professor. Apesar da insatisfação com a flexibilidade do tutor/professor, obtivemos aprendizado através do curso.

$\mathrm{Na}$ C21 é questionado se os estudantes recebem respostas rápidas ás suas dúvidas, incentivos e orientação quanto ao progresso nos estudos. $84,54 \%$ dos alunos responderam sim e 15,38\% responderam não. Como já foi dito, a EaD preza não somente pela flexibilidade do aluno, mas também do professor, que tem até 48 horas para responder os questionamentos, sem diminuir a qualidade do ensino. Ainda, o incentivo e orientação são características do bom profissional que preza pela qualidade do ensino.

Em relação à Flexibilidade, sabe-se que tem evoluído devido às NTCls aplicadas ao ensino, levando a um avanço da flexibilidade e acessibilidade, devido aos seus poderosos recursos, velocidade, programas e comunicação, descobrindo novos conceitos, lugares, ideias, avaliações e trocas de experiências. A flexibilidade é uma das grandes particularidades da $\mathrm{EaD}$, mas é importante alertar que a $\mathrm{EaD}$ flexibiliza, sim, o tempo e o local da aprendizagem, mas é necessário, para seu sucesso, organização do tempo, planejamento do que se faz ou será feito com os estudos, o que já foi discutido anteriormente. (Harasin,1990)

A Flexibilidade nos horários de estudo significa que o aluno pode estudar no horário que melhor lhe convir pois podem organizar pessoalmente seus horários de estudo e de realização das atividades propostas. Em TAPS a frequência dos alunos é "registrada" a partir do seu acesso a plataforma, por meio de suas participações em fóruns, chats, e envio de trabalhos agendados. 
A flexibilidade vem devido a uma combinação de tecnologias convencionais e modernas, que proporcionam, ao aluno, a possibilidade de estudar individualmente ou em grupo, em ambientes diversos, através de métodos de orientação e tutoria presencial ou à distância. $\mathrm{Na} \mathrm{EaD}$ semipresencial podem ocorrer atividades presenciais específicas, como reuniões de grupo para estudo e avaliações. O desafio é encontrar a melhor maneira de apresentar os conteúdos a serem trabalhados, de forma a atender ao princípio da flexibilidade das dimensões espaço e tempo e da diversidade entre aos alunos, que gere aprendizado efetivo do aluno.

$\mathrm{Na}$ C26 a pergunta é se existe padrão de qualidade do atendimento pelos tutores e demais profissionais do curso aos estudantes. A resposta por $81,54 \%$ foi sim e 18,46\% não, inserida aqui a satisfação do aluno com o curso, pois se não há qualidade de ensino através dos componentes da disciplina, como professor, tutor $\mathrm{e}$ monitor, não produzira um aluno satisfeito com o curso.

$\mathrm{Na}$ análise bivariada dos componentes da dimensão tutor com a variável dependente satisfação, e ao realizar o modelo de regressão logística multivariado com todos os itens, não se chegou a nenhum valor significativo. Nos levou a um $\mathrm{R}^{2}$ de 0.0639 , o que explica $6 \%$ da variável satisfação. Na Tabela 9 , regressão logística multivariada da dimensão tutor na variável satisfação, nos itens B9 e C6, podemos inferir que o modelo não foi considerado significativo, mostrando que esses itens não interferem na variável satisfação do aluno com o professor de EaD.

A Tabela 10 mostra a análise descritiva da dimensão Ambiente do Curso/Interação. Na C1, questiona-se se o Ambiente Virtual de Aprendizagem favorece a interatividade entre acadêmicos e docentes: $47,69 \%$ dos alunos responderam sim, e $52,31 \%$ não. A C2 pergunta se o Ambiente Virtual de Aprendizagem (AVA) favorece a interatividade entre acadêmicos e tutores. 81,54\% dos alunos responderam que sim, e 18,46\% que não. $\mathrm{O}$ item $\mathrm{C} 3$ se repete no $\mathrm{C} 25$, em que se questiona se o Ambiente Virtual de Aprendizagem incentiva a comunicação entre colegas: sim foi a resposta de $61,54 \%$ e não foi de $38,46 \%$; na C25, 55,38\% sim e 44,62\% não. Cruz, 2011, diz que a interatividade, elemento de comunicação, não é uma função do computador, mas ele é um meio de enviar e receber informações levando a interatividade entre professor e tutor. Então caso o computador não realiza essas funções perfeitamente, não haverá interatividade e 
nem a comunicação estará estabelecida. Uma vez que não exista comunicação não há interatividade levando o curso se tornar desinteressante ao aluno. No item C4, pergunta se o Ambiente Virtual permite ao aluno desenvolver com rapidez questões referentes ao material didático e seus conteúdos. 81,54\% responderam que sim e $18,46 \%$ que não. O material didático e seu conteúdo na $\mathrm{EaD}$, deve ser autoexplicativo para facilitar o aluno estudar sozinho, vencendo os desafios da disciplina adquirindo conhecimento gerando aprendizagem ao seu tempo. Sales, 2005 diz em seu artigo que o material didático é um mediador em EaD, que dirige o ensino aprendizagem.

No item C23, a pergunta o curso no Moodle promove a interação em tempo real entre os participantes, $69,23 \%$ sim e $30,77 \%$ não, ainda na C24, se é facilitado a interação entre estudantes, por meio das atividades coletivas, presenciais ou via AVA $84,62 \%$ sim, e 15,38\% não. A maioria dos alunos entendeu que o Ambiente Virtual favorece a interatividade no geral, seja com o tutor ou com os colegas, porém houve uma incompatibilidade do item $\mathrm{C} 1 \mathrm{com}$ o restante que trata de interatividade, onde a maioria dos alunos disseram que o Ambiente Virtual desfavorece a interatividade entre aluno e professor. Entende-se, então, que aqui acontece uma descaracterização da $\mathrm{EaD}$, pois nesse tipo de educação a interatividade ganha especial importância, uma vez que diminui o isolamento do aluno e favorece a troco contínua de diversas experiências. Lévy (2000), diz que a interatividade no mundo virtual é outra forma de ser sem estar, então, grosso modo, ela é responsável pelo sucesso ou insucesso do aprendizado nesse Ambiente Virtual, sendo um fator importante na variável satisfação. (SANTOS, 2010). Ainda no item C24, a pergunta é se existe uma facilitação para a interação entre os alunos, por meio de atividades coletivas, sendo presenciais ou virtuais, $84,62 \%$ disseram que sim e $15,38 \%$ que não. Falando ainda da importância da interação, Sales, 2005 diz que a interação é essencial e sempre deve estar presente para a garantia de que a aprendizagem será efetiva e de qualidade, isto porque existe na EaD o feedback que pode ser em tempo real e é uma via de mão dupla, a informação vai e vem. Desse modo a interação na EaD deve ser utilizada como referencial levando em consideração todo o processo ensino-aprendizagem, facilitando interação entre os alunos com atividades em grupos e até mesmo marcando um chat na própria plataforma aproximando todos. Sales 2005, apud, Andrade (2005) afirma que a: "interação 
social também influencia a afetividade, a interatividade e a aprendizagem como um todo. No momento em que os alunos adquirem confiança e consideração por seus pares (colegas e professores - reais ou artificiais), as relações interpessoais começam a se formar. Inicia-se um processo de motivação intrínseca, e os alunos vão interagir [...] e socializar seus textos e seus conhecimentos" (p. 257.)

O termo interação, segundo Piberan, 2011, refere-se ao "fenômeno que permite a certo número de indivíduos constituir-se em grupo, e que consiste no fato de que o comportamento de cada indivíduo se torna estímulo para o outro" e o termo interatividade está relacionado a componentes tecnológicos que promove a "[...] permuta entre o usuário de um sistema informático e a máquina, por meio da visualização" (PIBERAN, 2011). A distância física entre os componentes de EaD cria a necessidade de uma infraestrutura que permita interação entre os envolvidos. Onde é crescente a importância do tutor, pois ele atua junto ao aluno orientando-o para que ele desenvolva o seu próprio aprendizado adquirindo autonomia de estudo.

O tutor como mediador da interação entre todos, pode ser chamado ainda de "tecnólogo educacional", o qual que em meio a programas computacionais deve ser tornar cada vez mais aprimorado, já que a constante geração de novos equipamentos traz sempre novas informações aumentando a interatividade com possíveis ferramentas que possibilitam uma aproximação maior e mais eficaz entre aluno e conteúdo. A motivação e o comprometimento de todos componentes na EaD é fundamental para que se tenha interação. (Belloni, 2006)

A interface destes sistemas de aprendizagem deve ser amigável e intuitiva, com uma boa apresentação geral, para facilitar o seu uso e diminuir o processo exaustivo da busca de acesso a informação pelo usuário. Devemos ter bom desempenho tecnológico, funcionalidade do Ambiente Virtual de qualidade, bom funcionamento dos mecanismos de comunicação e mecanismos de cooperação e bom funcionamento das ferramentas de interação (síncrona e assíncrona). Aumentando a interação com a plataforma adquirindo uma melhor interação com a plataforma e todos componentes dos grupos através da EaD. O AVA não se apresenta apenas como recurso tecnológico, mas também como ferramenta para promover a interação e socialização de professores e alunos na EAD. (Guedes, 2005) 
Mendes Netto e Perpétuo (2010) apud Jean Piaget (1962), que diz que, para o pleno desenvolvimento da aprendizagem, o afeto e as relações sociais são fundamentais, onde a questão da afetividade é a chave necessária para aumentar a interação na EaD. Porém, ultimamente, tem a interação tem sido excessiva entre aluno e professor/tutor, porque além do contato no Ambiente Virtual do curso, interagem ainda por meio do correio eletrônico pessoal e até de forma presencial, quando possível, para atender às dúvidas. A comunicação não depende da disponibilidade do professor, pois o aluno pode mandar a mensagem em qualquer momento, enquanto na forma presencial ele precisava encontrar um momento em que o professor possa dialogar, causando sobrecarga aos professores e tutores.

$\mathrm{Na}$ Tabela 11, análise estatística da dimensão Ambiente do Curso, interação em relação à variável satisfação, utilizando-se o teste exato de Fisher, com alfa $=0,05$, foi observado que nenhum dos itens avaliados na dimensão apresentou valor significativo, pois nenhum foi abaixo de 0,05 . Ainda na Tabela 12, regressão logística multivariada para a mesma dimensão, não houve diferença significativa entres as variáveis independentes e a variável satisfação. Então, o modelo multivariado gerado demonstrou que os constructos não foram determinantes para a variável satisfação. As demais variáveis, C2, C3, C4 e C 24, não foram computadas uma vez que os alunos que responderam insatisfeitos com a disciplina nesses itens responderam positivamente.

$\mathrm{Na}$ análise descritiva da dimensão Curso/Disciplina, indicado na Tabela 13, o item C8 que aborda a questão se os momentos presenciais são planejados e informados aos estudantes com antecedência: $92,31 \%$ sim, e 7,69\% não. Na matéria TAPS, desde o início do curso as aulas presenciais já estão marcadas no calendário que está na plataforma, se houver qualquer imprevisto o novo encontro é marcado com antecedência de 15 dias a até 1 mês. Sales, 2005, afirma uma necessidade de um planejamento real de todo o cronograma do curso em EaD, pois isso irá potencializar todo o aprendizado.

No item C9, questionou-se se os recursos didáticos utilizados na disciplina são de boa qualidade, $98,46 \%$ sim e $1,54 \%$ não e no $C 17$, se o material didático indicado para a disciplina é de boa qualidade, 95,38\% sim e 4,62\% não. Possoli, 2009, apresentou que os materiais e recursos didáticos na EaD são o quais estão 
diretamente interligados ao processo de ensino-aprendizagem, e por isso tem características especificas quando apresenta o conteúdo. Sabemos que a disciplina, por ser à distância, necessita de cuidado maior com os materiais e recursos didáticos, pois eles têm a responsabilidade de guiar 0 aluno, deve ser autoexplicativo e que facilite o aprendizado, levando o aluno a se sentir dentro do material, como se estivesse em sala de aula. $O$ aprendizado deve ser centrado na disponibilidade de materiais didáticos de boa qualidade, onde o aluno navega pelos materiais, busca informações, realiza as atividades propostas, internaliza-as, apropria-se delas e as transforma em uma nova representação, ao mesmo tempo que se transforma e volta a agir no grupo transformado e transformando o grupo, compartilhando seus conhecimentos. (Baranauskas, Rocha, Martins e D'Abreu, 1999)

Deve-se elaborar material didático que possibilite a autonomia do aluno empregando objetos de aprendizagem diversificados para evitar a monotonia com indicações de fontes variadas de informações para se chegar a resposta do questionamento feito. $O$ material didático deve ser atrativo e integrativo estimulando a aprendizagem. (RIBEIRO; MENDONÇA, G.; MENDONÇA, A. 2007)

E no item $\mathrm{C} 12$, se no desenvolvimento da disciplina se teriam a relação teoriaprática, $72,31 \%$ sim e $27,69 \%$ não e no item C19, se o curso oferece atividades de aplicação prática dos conteúdos estudados, onde 56,92\% sim e 43,08\% não. Azevedo, 2007, diz que a relação teoria-prática na EaD não apresenta espaços definidos e nem tempo determinado, ao passo que leva o professor a uma avalição constante de todos envolvidos, independentemente de estarem participando do curso ao mesmo tempo. Ainda assim, a prática em $\mathrm{EaD}$ não deve limitar à criatividade de seus componentes, mas sim ser um desafio constante de superação de limites através do domínio do conteúdo e a utilização dos recursos tecnológicos. $\mathrm{Na} \mathrm{C} 14$, a pergunta é se a carga é compatível com o conteúdo da disciplina, 95,38\% sim, e 4,62\% não. Na legislação de $\mathrm{EaD}$, no art. 4ํㅡㄹ no segundo parágrafo, na letra $\mathrm{E}$, diz que cada carga horária deverá ser projetada de acordo com a modalidade. Ainda 0 art. $8^{\circ}$ afirma que os cursos à distância devem garantir a mesma carga horária adaptada ao que foi definido legalmente no curso presencial, não se esquecendo, obviamente, que a EaD tem suas peculiaridades, pois depende do tipo de matéria, do tempo que será disponível, local, população e etc. A disciplina TAPS 
é de 2 créditos que corresponde a $30 \mathrm{Hs,} \mathrm{então} \mathrm{de} \mathrm{acordo} \mathrm{com} \mathrm{o} \mathrm{que} \mathrm{a} \mathrm{disciplina}$ dispõe pode-se inferir que a carga horária é compatível.

$\mathrm{Na}$ C15 foi questionado se existe a disponibilidade de tempo para o estudo e desenvolvimento de atividades relacionadas a disciplina, aqui 90,77\% responderam que sim e 9,23 que não. Na matéria TAPS, as atividades são semanais, então no domingo a 00:00Hs o professor libera o assunto da próxima semana, o aluno tem até o próximo domingo as 23:55 para ler o material proposto se inteirando do assunto, pesquisar e responder a questão podendo assim ser avaliado. A maioria respondeu positivamente a esse item o que ficou de acordo com a proposta da disciplina. No item C16, se os conteúdos da disciplina estavam relacionados com os conteúdos das demais disciplinas dos cursos de graduação, aqui 95,38\% responderam que sim e 4,62\% que não e na C18, foi perguntado se existia repetição de conteúdos já abordados em outras disciplinas, ao passo que $78,46 \%$ responderam que sim e $21,54 \%$ que não. Por se tratar de uma disciplina voltada a saúde onde os participantes desta pesquisa eram todos da área da saúde, tanto a C16 quanto a C18 são autoexplicativas devido a esse quadro de ser um curso da saúde aplicado para alunos da saúde, onde se torna praticamente impossível não se repetir algum conteúdo propriamente dito, ou próximo.

$\mathrm{Na} \mathrm{C20,} \mathrm{pergunta-se} \mathrm{se} \mathrm{a} \mathrm{disciplina} \mathrm{proporciona} \mathrm{aos} \mathrm{estudantes} \mathrm{a}$ oportunidade de desenvolver projetos compartilhados: $69,23 \%$ sim, e $30,77 \%$ não. A EaD apresenta um tipo de aprendizagem totalmente inovadora que deve proporcionar ao aluno a oportunidade de interagir e desenvolver projetos compartilhados utilizando NTCls que proporcionem a efetiva integração. (MEC, 2007) Com a EaD, é preciso desenvolver a consciência de que tudo o que for lido, todas as ideias, saberes e sentimentos coerentes com a disciplina devem ser compartilhados, não apenas para serem corrigidos, mas para adquirir novas experiências por meio de uma troca constante, construindo o conhecimento.

A C22, pergunta se é assegurada a flexibilidade no atendimento ao estudante, oferecendo horários ampliados para o atendimento tutorial, 69,23\% responderam que sim e 30,77\% que não. A disciplina TAPS tem disponível 1 tutor para cada 20 alunos, disponíveis $24 \mathrm{hs}$, o que está descrito na ementa da disciplina e também recomendado pelo Neder, 1999, o que foi explicado no item C7, que essa 
seria a relação ideal para não se colocar em risco a qualidade do curso sabendo a importância do atendimento individual e único ao aluno. Porém é de conhecimento mútuo que não só os tutores como qualquer componente do curso, nem sempre conseguirá dar um feedback instantâneo ao aluno.

A C27 questiona se o material didático é estruturado em linguagem dialógica de modo a promover autonomia ao estudante em desenvolver sua capacidade para aprender e controlar o próprio desenvolvimento, 92,31\% responderam que sim, 6 , $15 \%$ que não e $1,54 \%$ não responderam. Como já foi discutido nos itens $C 4, C 19$ e C17, o material didático e seu conteúdo na $\mathrm{EaD}$ devem ser da melhor maneira autoexplicativa possível, de fácil entendimento e com linguagem adequada para facilitar o aluno estudar sozinho, adquirindo conhecimento gerando aprendizagem de acordo com o seu tempo. No item C28, o questionamento é se a disciplina proporciona aos estudantes construir conhecimento, onde $98,46 \%$ que sim e 1,54\% que não. A proposta principal de $\mathrm{EaD}$ é que os alunos tenham a oportunidade de construir o conhecimento juntamente e sincronizadamente com os outros alunos do curso, usando essa interação de conhecimentos por meio de debates em fóruns transformando em aprendizagem.

Ainda na Tabela 14, realizou-se uma análise bivariada dos componentes da dimensão Curso/Disciplina, com a variável satisfação através do teste de Fisher, resultando em que nenhum dos itens avaliados nesta dimensão apresentou valor significativo para a variação satisfação, entendendo que nenhum desses itens interfere diretamente na satisfação mesmo na regressão logística multivariada, juntando todos os itens encontramos um valor de 0.1742 , determinando um $R^{2}$ de 0.3879 , ainda não sendo significativa. $E$, na Tabela 15 , que mostra a regressão logística multivariada desta dimensão, as variáveis não tiveram valor significativo, salvo a variável $\mathrm{C} 14$, que indicou um valor de p 0.000 , o que mostrou significância estatística, podendo ser utilizado em um modelo estatístico no futuro. A C14, sobre a carga horária ser compatível com o conteúdo da disciplina, como este escrito no art. 4, a carga horária tem que ser compatível com a matéria, entende-se que a matéria TAPS seja harmonizável com o conteúdo proposto conseguindo alcançar a aprendizagem. As variáveis C8, C16, C17 e C27, não participaram da amostra já que os alunos que estavam insatisfeitos com a disciplina responderam positivamente, e a C28 não foi considerada pois houve unanimidade nas respostas. 
A análise descritiva dos componentes da dimensão Aluno, Tabela 16, no primeiro item B10, em que a pergunta foi se a avalição serviria para controlar e classificar o aluno do que um processo de correção e construção de conhecimento, $58,46 \%$ responderam sim, e 41,54\% não. Segundo Nunes 2012, apud Maia et al. (2005), a avaliação em EaD, pode ser de três maneiras: Presencial, em que o aluno deve estar acompanhado de um professor ou outra pessoa responsável, realizada com hora, data e local pré-determinados; à distância, com aplicação de teste on-line, que deve ser enviado depois de respondido para o formador por e-mail ou formulários de envio, realizado em tempo e local de escolha do aluno, mas com datas limites para entrega; e, por último, avaliação contínua ao longo do curso, baseada em situações em que o professor avalia continuamente por meio de atividades realizadas, postagem de comentários, participações em grupos de discussão e em chats, etc. De acordo com o que foi explanado a matéria TAPS utiliza a avaliação ao longo do curso, através das postagens no tempo pedido, de acessos a plataforma e aos conteúdos propostos e ainda pela participação de discussões no fórum.

Item C10, pergunta se há compatibilidade da avaliação da aprendizagem com o conteúdo trabalhado, 98,46\% responderam que sim e 1,54\% que não, ao passo que a avaliação, tem como função demonstrar se o aluno conseguiu absorver algum conteúdo do que foi proposto adquirindo aprendizagem, TAPS utiliza justamente um tipo de avaliação do aluno através da atividade constante do mesmo na plataforma, observando se os trabalhos, as respostas, postagens e discussões se estão de acordo com o conteúdo. No item $\mathrm{C} 11$, questiona-se se existe diversidade de instrumentos de avaliação, 67,69\% responderam que sim e 32,31\% que sim. Ao passo que os instrumentos de avaliação dentro de TAPS são os que fazem parte de uma disciplina de EaD, trabalhos, postagens, fórum, e desta forma o aluno é avaliado. Ainda no item C13, pergunta se os trabalhos de grupo desenvolvidos na disciplina atingiram os objetivos que se propuseram, aqui $81,54 \%$ responderam que sim, $16,92 \%$ que não e ainda 1,54\% não responderam. O trabalho em grupo é uma estratégia pedagógica que tem como principal objetivo é a interação entre os alunos estimulando-os, obtendo como resultado a aprendizagem de ambos podendo proporcionas condições participativas e colaborativas do grupo. (KENSKI, 2006). 
Não é possível pensar em formação da autonomia dos estudantes com os saberes organizados, sem pensar em avaliação, pois como o aluno apresenta currículos lineares, que pressupõem previamente que tenha vencido várias etapas, sem ter sido avaliado. A avaliação não deve ser usada somente para decretar promoções e reprovações deve ser "um divisor" que separa uma disciplina da outra, uma fase de outra. A dificuldade de implementar avaliação em cursos de Educação à Distância pode ser minimizada por meio do suporte das NTCls, tão presentes nos processos de educação à distância e muito pouco utilizadas em benefício da avaliação. Um projeto, Projeto Teedode1, Universidade de Barcelona, afirma que a avaliação na EaD tem feito pouco uso da tecnologia, realizou-se uma pesquisa com intuito de investigar os métodos de avaliação como forma de obtenção dos resultados de aprendizagem, em instituições que trabalham com Educação à Distância, em 15 países membros da União Europeia.

A avaliação da aprendizagem constitui-se um elemento fundamental do processo educativo, no entanto as novas formas de ensinar, EaD, não trazem consigo as novas formas de avaliar. Sendo assim, a avaliação em EaD deve ser com uma possibilidade de troca, interatividade, comunicação, compartilhando suas ideias tendo produção individual e coletiva de conhecimentos, por meio do suporte em ambientes digitais de interação e aprendizagem (Almeida, 2002). A avaliação é a mesma, não se trata de substituição de moldes velhos por novos e sim da compreensão do novo contexto, do novo ambiente on-line que atende às novas demandas educacionais.

Em TAPS a avaliação do aluno acontece a todo momento, de acordo com suas postagens, participação em fóruns, e trabalhos entregues. Isso leva a um tipo de avaliação que valoriza as quantidades aprendidas de conhecimentos transmitidos gerando um modelo de avaliação em que os alunos têm a oportunidade de demonstrar o conhecimento que construíram, como construíram, o que entendem e o que podem fazer, isto é, um modelo que valoriza as aprendizagens quantitativas e qualitativas no decorrer do próprio processo de aprendizagem. "A avaliação educacional vem sofrendo uma transformação radical com a mudança da cultura da prova para a cultura da avaliação" (Souza 2012, apud Vianna, 1997). Todo o Ambiente Virtual possui um dispositivo que registra data e hora de acesso do professor e dos alunos. A EaD garante o registro de cada passo do aluno, dando 
destaque à avaliação processual, uma vez que é possível saber quantas vezes ele entrou no AVA, o tempo passado em chat e fóruns e qual a qualidade dessa participação. Desse modo, pode- se verificar se o aluno está interagindo ou não e se os resultados são positivos no que diz respeito à aprendizagem; todo esse "conjunto" também se caracteriza como um método avaliativo. Entende-se que a avaliação é constituir-se como parte do processo de ensino-aprendizagem, permeando e auxiliando todo este processo, não mais como uma atividade em momentos pontuais, mas sim fluindo durante todo o curso.

Cerny 2001, apud Both 1999, propõe a "avaliação-ensino", mostrando a avaliação e o ensino são como processos de aprendizagem. $O$ autor relata que a avaliação vem sendo usado mais como instrumento de que como um processo do ensino. A avaliação e o ensino devem manter simultaneidade e concomitância de ação, de intervenção e de efeito, pois ensinando avalia-se e avaliando ensina-se, ao mesmo tempo. Santos, 2006 apud Piletti 1987, diz que a avaliação é um processo contínuo de pesquisas que visa interpretar os conhecimentos, habilidades e atitudes dos alunos, tendo em vista mudanças esperadas no comportamento, propostas nos objetivos educacionais, a fim de que haja condições de decidir sobre alternativas do planejamento do trabalho do professor e da escola como um todo.

$\mathrm{Na}$ análise bivariada dos componentes da dimensão avaliação com a variável satisfação, feita através do teste de Fisher, representada na Tabela 17, observou-se que somente $o$ item, Trabalhos de grupo desenvolvidos na disciplina atingiram os objetivos a que se propuseram, obteve valor de $p$ de 0.001 , onde existe uma porcentagem de pessoas que não ficaram satisfeitos com o que foi colocado, não atingindo o objetivo do trabalho em grupo que é uma estratégica pedagógica para promover a interação dos alunos agregando conhecimento. (KENSKI, 2006).

No modelo de regressão logística multivariado para a dimensão Avaliação, não foi possível gerar um modelo, porque as variáveis $\mathrm{C} 10$ e $\mathrm{C} 11$, os alunos que responderam foram os que se julgavam insatisfeitos, e a resposta foi positiva causando incompatibilidade nos resultados. E nos itens B10 3 C13 foi ao contrário aonde que os alunos insatisfeitos com a disciplina responderam negativamente julgando que as avaliações e os trabalhos em grupo não atingiram seus objetivos. 
$\mathrm{Na}$ análise descritiva dos componentes da dimensão satisfação, representada na Tabela 18, o item C29 é o carro-chefe da pesquisa e foi o que fez combinação com todos os outros itens para tentar justificar a ligação de satisfação com os demais. Item C29, pergunta ao aluno se ele está satisfeito com a aprendizagem decorrente da disciplina, 93,85\% responderam que sim e 6,25\% que não. Então satisfação segundo Kotler, 2007, consiste em sensações de prazer ou desprazer que são resultados de uma comparação feita pelo próprio aluno em relação ao desempenho da disciplina. De acordo com os resultados podemos subtrair que a disciplina tem qualidade, pois a presença da satisfação dos alunos é um indicador de qualidade. Segundo Marks, Sibley e Arbaugh (2005) a satisfação em cursos pela $\mathrm{EaD}$ é consideravelmente influenciada pelo comportamento e atitudes dos professores, tutores e monitores, material e recursos didáticos, ambiente, trabalhos em grupos e avalições, todos são de extrema significância para conduzir o curso com dinamismo, integração e motivação constante dos alunos, atingindo o objetivo principal que a aprendizagem de forma democrática. No item C30, se o aluno adquiriu algum conhecimento a mais, 89,23\% responderam que sim e 10,77\% que não, como a disciplina à distância tem o processo de ensino-aprendizagem, onde existe uma troca infinita de informação com a finalidade de interagir, culturas raças e classes sociais, colocando em contato e em troca de experiências não é de se admirar que a maioria tenha terminado o curso com uma aprendizagem diferenciada e com maior conteúdo. Ainda no item C31, pergunta-se se o investimento feito na disciplina foi valido, $100 \%$ responderam que sim, foram unanimes, os que estavam satisfeitos com a disciplina já era de se esperar que tivesse feito um bom investimento, mas com esse resultado até os que se julgaram insatisfeitos com a matéria, as vezes até colocando que não adquiriram nenhum conhecimento através da disciplina, entenderam que fizeram um bom investimento. No item C33, perguntase se realizariam outra matéria no Moodle futuramente, 96,92\% responderam que sim e 3,08\% que não. Conclui-se que a matéria TAPS alcançou o seu objetivo, de primeiramente apresentar aos alunos uma disciplina EaD, conquista-los com assunto, disciplina, interação e conteúdo atualizados quebrando tabu de muitas que esse tipo de ensino não tem qualidade e o resultado é que o investimento foi aprovado por unanimidade e ainda quase $100 \%$ disseram que fariam outra disciplina por Moodle. 
$\mathrm{Na}$ análise bivariada dos componentes da dimensão Avaliação com a variável dependente satisfação, representada na Tabela 19, observou-se que o item C33 teve um valor de $p 0.003$, que mostra uma diferença estatisticamente significativa, em que os alunos responderam que fariam outra matéria Moodle, mostrando que os mesmos adquiriram conhecimento gerando aprendizagem através da disciplina TAPS. O restante não apresentou valor de $p$ significativo. No modelo de regressão logística multivariado para a dimensão Satisfação, Tabela 20, quando foram incluídos todos os itens, gerou-se um valor de $p$ de 0.1379 , não sendo significativo, mas determinou um $R^{2}$ de $0.1251,0$, o que explicou aproximadamente $12 \%$ da variável satisfação sendo de significância. Ainda o item C31 obteve um valor de $p$ de 0.110 não apresentando significância estatística, e as seguintes variáveis, C32 e C33, não foram computadas já que os que se julgaram insatisfeitos responderam positivamente a esses itens, o que os exclui da amostra.

De acordo com os aspectos facilitadores e dificultadores do processo de ensino-aprendizagem, foi pedido que o aluno citasse três de cada um. Os aspectos facilitadores mais citados foram, com $45 \%$ a flexibilidade de horário para realização das atividades da disciplina e a flexibilidade de local para realização das atividades e fácil acesso ao material didático/conteúdo da disciplina com cerca de 32\% dessa população. $O$ ensino à distância indica que as dimensões tempo e espaço deixam de ser restrições e ganham flexibilidade, de horários e local, que são aspectos singulares na EaD. Uma combinação de tecnologias convencionais e modernas, proporcionam, ao aluno, a possibilidade de estudar individualmente ou em grupo, em ambientes diversos. Através dela o aluno pode ter acesso ao conteúdo, material e aos componentes do grupo a qualquer hora e local, independente se estão ao mesmo tempo conectados. E ainda a flexibilidade de local leva a possibilidade de alunos de diferentes localidades, cidades, estados e até em países diferentes, receberem o mesmo material, a mesma explicação, a mesma interação e juntos responderem aos questionamentos feitos pelo professor. (SILVA, 2004). Ainda sobre o fácil acesso ao material Pacheco, 2012, diz que todo o material para EaD deve sempre se considerar a adequação de uma linguagem de fácil acesso e entendimento, permitindo que o aluno tenha acesso a todo o conteúdo necessário para a aprendizagem sem grande necessidade de interferência seja do professor ou tutor. 
Dentre os aspectos dificultadores o mais citado foi a pequena interação entre os componentes do curso com $25 \%$ da opinião dos alunos. Seguido pela flexibilidade de horário para atendimento dos alunos com $18 \%$ da população. De acordo com o Neder, 1999 estipulou a relação ideal seria de 1 tutor para cada 20 a 30 alunos já que o atendimento individua é o principal critério que permite uma interação de qualidade entre os componentes. Sales, 2005 diz que a interação é essencial e sempre deve estar presenta para a garantia de que a aprendizagem será efetiva e de qualidade. Assim, a interação na EaD deve ser utilizada como referencial, facilitando-se a interação entre os componentes. Ainda no que diz respeito à flexibilidade de horário para atendimento, como já foi dito, os responsáveis pela disciplina TAPS, professores e tutores, têm até 48 horas para sanar qualquer dúvida pertinente à disciplina, conteúdo ou outros. A flexibilidade da disciplina TAPS não é somente para o aluno, mas também para tutores e professores claro que desde que não seja prejudicial ao aprendizado dos alunos.

Por meio da presente pesquisa, tem-se que alcançar melhorias em relação à interação para que seja satisfatória e a flexibilidade do professor; tutor para se ter uma melhor formação do aluno, a flexibilidade de hora e local, juntamente com o fácil acesso ao material didático foram importantes fatores para o sucesso da disciplina à distância TAPS. Precisamos de Instituições, públicas e particulares, que abracem uma proposta integrada de utilização das tecnologias disponíveis, respeitando as possibilidades e limitações regionais e condições sociais de nossa comunidade brasileira, estimulando a cada dia a procura por aprendizado por meio da EaD, melhorando a nossa mão de obra da saúde.

Sendo estimulador esse novo modelo de educação, tem-se como consequência a motivação continuada na $\mathrm{EaD}$, levando à possibilidade de interagir e construir o saber, e de colaborar com o conhecimento, produzindo conteúdo, levando o aluno a ir além do que the foi proposto, melhorando a saúde do Brasil, onde todos ganham: o profissional ganha conhecimento adquirido e reconhecimento pessoal, o que leva a um aumento salarial, e o paciente ganha um profissional de saúde mais qualificado e satisfeito com a profissão e ainda a educação ganha com o crescimento do interesse da população em se aperfeiçoar. 
Quem sabe assim possamos caminhar mais um pouco para garantir um sistema de saúde verdadeiramente justo, que privilegie o sentido do direito à saúde sem a contaminação do consumo de saúde e, sobretudo, que atenda os reais interesses da sociedade como um todo. (SANTOS, 2015)

\section{CONCLUSÃO}

De acordo com a metodologia utilizada no presente trabalho pode-se alcançar resultados aceitáveis afirmando a Satisfação.

Conclui-se então que o perfil dos alunos de TAPS foi caracterizado com a maioria sendo do sexo feminino, $74 \%$, com idade entre 20 a 30 anos, $89 \%$, solteiros $89 \%$, sem filhos, $86 \%$. A maioria deste universo cursava Enfermagem, 35\%, no 
oitavo ou nono semestre, $21 \%$ e $28 \%$ respectivamente e o acesso a disciplina era feito a domicilio com $88 \%$.

Ainda foi identificado que a Satisfação em $\mathrm{EaD}$ foi influenciada principalmente pelo constructo Aluno, que foi a única dimensão que gerou um modelo de regressão estatisticamente significativo, explicando $56 \%$ da variabilidade da variável Satisfação. Os aspectos facilitadores mais citados foram: Flexibilidade de Horário e Local, acesso fácil ao material didático, facilidade na linguagem do material didático, e facilidade em acessar a plataforma. Os aspectos dificultadores mais encontrados foram: Falta de Flexibilidade do professor/tutor no atendimento ao aluno e pequena interação entre os componentes.

\section{REFERÊNCIAS}

ABREU, M. T; LAGUNA, M. R (2010). Formação Permanente de Profissionais da Saúde - limites e possibilidades da educação à distância. Disponível em: < http://www.abed.org.br/revistacientifica/Revista_PDF_Doc/2010/2010_245201 0111329.pdf> Acesso em: 05 nov. 2013. 
AGUILLAR, C. SILVA, D. Cabreira, M. O PERFIL SOCIOECONÔMICO DOS ALUNOS DA FATEC GARÇA: análise estatística para o desenvolvimento de ações pedagógicas focadas no acesso, permanência e emancipação dos alunos. Faculdade de Tecnologia de Garça (FATEC-Garça)- SP. 2013. Disponível em

http://www.fatecgarca.edu.br/revista/Volume3/artigos vol3/Artigo 9.pdf> Acesso em: 15 jan. 2016.

ALCÂNTARA, V. de C.; LUIZ, G. V.; FERREIRA, A. C.; TEODORO, S. A. S. Dimensões e determinantes da satisfação de alunos em uma instituição de ensino superior. REMark - Revista Brasileira de Marketing, São Paulo, v. 11, n. 3 , p. 193-220, set./dez. 2012. Disponível em < http://www.spell.org.br/documentos/ver/9301/dimensoes-e-determinantes-dasatisfacao-de-alunos-em-uma-instituicao-de-ensino-superior> Acesso em: 20 jan. 2016.

ALMEIDA, V. P., and J. C. A. SILVA. "Planejamento Estratégico para Educação Apoiada por Computador Visando a Produção de Material Instrucional para EAD Baseado em Estratégias Cognitivas." WIE 2004 Workshop de Informática na Escola, Anais do XXIV Congresso da Sociedade Brasileira de Computação. 2004. ACESSO EM: 10 jul. 2013.

ALMEIDA, Maria Elizabeth Bianconcini de. "Tecnologia e educação a distância: abordagens e contribuições dos ambientes digitais e interativos de aprendizagem." Revista Brasileira de Educação a Distância(2011): 6. Disponivel em < http://www.ipae.com.br/pub/pt/re/rbead/110/110.pdf\#page=6 $>$ Acesso em: 15 jan. 2016

ALVES, E. et al. Educação à distância nas instituições federais de ensino superior: A situação da enfermagem Brasileira. Ver. Eletrônica de enfermagem, V.7, N.01, p.41-53, 2001. Disponível em: < www.fen.ufg.br >. Acesso em: 02 nov. 2013.

ALVES, E. (2014). Educação a distância nas instituições federais de ensino superior: a situação da enfermagem brasileiras. Disponível em: 
http://biblioteca.versila.com/?q=Alves\%2C+Elioenai+Dornelles\&dc=author Acesso em 15 nov. 2015.

ALVES, J. R. M. A história da EaD no Brasil. Educação a Distância: o estado da arte. São Paulo: Pearson Prentice Hall, 2009. Disponível em: <http://www.eadeducar.com.br/ead/artigos.html>. Acesso em: 05 nov. 2013.

ALVES, L. (2011). Educação a distância: conceitos e história no Brasil e no mundo. Disponível em:

http://www.abed.org.br/revistacientifica/Revista_PDF_Doc/2011/Artigo_07.pdf >. Acesso em: 02 nov. 2013.

ANDRADE, A.A.M. Política e afeto na produção de identidades e instituições: a experiência potiguar. Revista Brasileira de Educação, n.30, set. /out. /Nov./dez. p. 133 a 181, 2005. Disponível em < http://www.scielo.br/pdf/rbedu/n30/a11n30> ACESSO EM: 05 abr. 2013.

ARETIO, Lorenzo Garcia. La educación a distância: de La teoria a La pretica. Espanha: Editorial Ariel, 2006. Disponível: < http://www.academia.edu/3260161/La educaci\%C3\%B3n a distancia> Acesso em: 12 fev. 2015.

AZEVEDO, Wilson. "Panorama atual da EaD no Brasil." Conect@-número (2000). Disponível em < http://www.aedmoodle.ufpa.br/pluginfile.php?file=\%2F46575\%2Fmod resourc e\%2Fcontent\%2F0\%2FPanoroma atual da EAD no Brasil.pdf> ACESSO EM: 12 fev. 2015.

AZEVEDO, Wilson. "EAD Antes e Depois da Internet." (2007). ACESSO EM: 18 jan. 2013.

Baranauskas, Maria Cecília Calani, et al. "Uma taxonomia para ambientes de aprendizado baseados no computador." Valente, JA O computador na sociedade do conhecimento. Campinas, SP: UNICAMP/NIED (1999). Disponivel em http://www.pucrs.br/famat/viali/tic literatura/capitulos/cap3taxion.pdf Acesso em: 10 jan. 2016 
BARBERO, Jesús. Ensanchando territórios en Comunicación/Educación, América-latina: otras visiones de La cultura CAB, Bogotá, 2005.

BARRETO, Raquel Goulart. "As políticas de formação de professores: novas tecnologias e educação a distância." Tecnologias educacionais e educação a distância: avaliando políticas e práticas. Rio de Janeiro: Quartet (2001): 10-28.

BARROWS, H. S. (1994). Problem-based learning applied to medical education. Disponível em: < http://edo.med.miami.edu/problem-basedlearning/subsect-background-reading-for-pbl> Acesso em: 05 nov. 2012.

BASTOS, M.A.R; GUIMARAES, E.M.P. Educação a distância na área de enfermagem: Relato de uma experiência. Rev. Latino- AM enfermagem, V.11, N.5, p. 685-691, 2003. Disponível em: < http://www.fen.ufg.br/fen_revista/revista7_1/original_04.htm> Acesso em: 10 nov. 2012.

BELLONI, M. L. Ensaio sobre Educação a Distância no Brasil. Educação \& Sociedade, ano XXIII, n. 78, abr. 2002. [on line] Disponível em: <http://www.scielo.br/scielo.php?script=sci_arttext\&pid=S01017330200200020 0008\&lng=en\&nrm=iso\&tlng=pt $>$. ACESSO EM: 15 nov. 2014.

BELLONI, Maria Luiza. Educação a distância. Autores Associados, 1999. Disponível em $<$ https://books.google.com.br/books?hl=pt$B R \& \mid r=\& i d=B c i u H d H I H P w C \& o i=f n d \& p g=P A 3 \& d q=B E L L O N I,+$ Maria + Luiza.$+E$ duca\%C3\%A7\%C3\%A30+a+dist\%C3\%A2ncia.+Autores+Associados,+1999.+ \&ots=ESMZKtksrS\&sig=E8qX74Dyh9b7hHhuv0qXp_FolUA\#v=onepage \&q=B ELLONI\%2C\%20Maria\%20Luiza.\%20Educa\%C3\%A7\%C3\%A30\%20a\%20dis t\%C3\%A2ncia.\%20Autores\%20Associados\%2C\%201999.\&f=false>ACESSO EM: 13 jan. 2016.

BERNARDO, V. "Educação a distância: fundamentos." Universidade Federal de São Paulo UNIFESP. Disponível em:< http://www. virtual. epm. br/material/tis/enf/apostila. htm\# INTRODUÇÃO>. ACESSO EM: 18 fev. 2013. BOTEGA, L. R. A Conferência de Jomtien e a Educação para Todos no Brasil dos anos 1990. In: Revista Educação on-line. Publicado em 18 set. 2005. 
Disponível em: http://www.educacaoonline.pro.br. ACESSO EM: 25 mar. 2013.

BRAGA, E. D. "Os elementos do processo de ensino-aprendizagem: Da sala de aula à educação mediada pelas tecnologias digitais da informação e da comunicação (TDICs)." Revista Vozes dos Vales: Publicações Acadêmicas. Reg 120 (2012): 095-2011. ACESSO EM: 20 out. 2012.

BRASIL, Decreto n. 2494, de 10 de fevereiro de 1998b. [on line]. Disponível em: $<$ http://www.rj.senac.br/psenac/ ead/portalcte/areas/regulamenta\%E7\%E3o-ead.htm> ACESSO EM: 26 mar. 2014.

BRASIL, MDE, and DICEI SEB. "Diretrizes Curriculares Nacionais Gerais da Educação Básica." Brasília: MEC (2013).

BRASIL. Congresso Nacional. Constituição da Federativa do Brasil. Promulgada em 5 de outubro de 1988, Brasília: Senado Federal, 1988. Disponível em

$<$ http://www.planalto.gov.br/ccivil 03/constituicao/ConstituicaoCompilado.htm> ACESSO EM: 13 jul. 2013.

BRASIL. Congresso Nacional. Lei de Diretrizes e Bases da Educação Nacional. Lei n. 9.394, de 20 de dezembro de 1996. [on line]. Disponível em: <http://www.sisbin.ufop.br/> ACESSO EM: 08 set. 2014.

BRASIL. Congresso Nacional. Lei Orgânica da Saúde. Lei nº 8.080, de 19 de setembro de 1990 . [on line]. Disponível em: <http://www.soleis.adv.br/leiorganicadasaude.htm> ACESSO EM: 08 set. 2014

BRASIL. Constituição (1988). Constituição da República Federativa do Brasil. Brasília, DF: Senado Federal, 1988. Disponível em: < http://www6.senado.gov.br/legislacao/ListaPublicacoes. action?id=102408> Acesso em: 10 nov. 2012.

BRASIL. Indicadores de qualidade para cursos de graduação a distância. 1998a. [on-line]. Disponível em: 
<http://www.ufrn.br/ufrn/conteudo/administracao/secretarias.htm>

ACESSO EM: 08 set. 2014.

BRASIL. Lei o 9.394, de 20 de dezembro de 1996. As Diretrizes e Bases na Educação.

Disponível em: http://www.planalto.gov.br/ccivil_03/leis/L9394.htm> Acesso em: 11 nov. 2012 BRASIL. Ministério da Saúde. Portaria № 198/GM/MS de 13/2/2004. Institui a Política Nacional de Educação Permanente em Saúde como estratégia do Sistema Único de Saúde para a formação e o de trabalhadores para o setor e dá outras providências. Brasília; 2004. Disponível em: < http://dtr2001.saude.gov.br/sas/PORTARIAS/Port2004/GM/GM-198.htm> Acesso em: 08 nov. 2012.

BRASIL. Ministério da Saúde. Secretaria de Gestão do Trabalho e da Educação na Saúde. Departamento de Gestão da Educação na Saúde. Portaria n 198/GM/MS de 13 de fevereiro de 2004a. [on line]. Disponível em: http://dtr2001.saude.gov.br/portarias/2004 1.htm ACESSO EM: 27 set. 2014.

BRASIL. Ministério da Saúde. Secretaria de Gestão do Trabalho e da Educação na Saúde. Departamento de Gestão da Educação na Saúde. Política do Ministério da Saúde para o Fortalecimento e Ampliação dos Processos de Mudança na Graduação em Saúde: Aprender SUS. 2004b. [on line].

Disponível em:

$<$ http://portal.saude.gov.br/portal/sgtes/visualizar_texto.cfm?idtxt=22419> ACESSO EM: 27 set. 2014.

BRUNNER, José Joaquim. "Educação no encontro com as novas tecnologias. Educação e novas tecnologias: esperança ou incerteza" (2004): 17-75.

BUSARELLO, Raul Inácio, Patricia Bieging, and Vania Ribas Ulbricht. Mídia e Educação: novos olhares para a aprendizagem sem fronteiras. Pimenta Cultural, 2013. Disponível em< https://books.google.com.br/books?hl=pt-

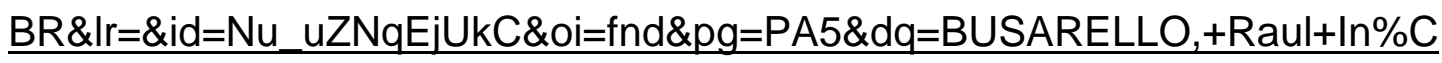
$3 \% \mathrm{~A} 1 \mathrm{cio},+$ Patricia + Bieging,+ and + Vania + Ribas + Ulbricht.+M\%C3\%ADdia $+e+E$ duca\%C3\%A7\%C3\%A30:+novos+olhares+para+a+aprendizagem+sem+front eiras.+Pimenta+Cultural, $+2013 . \&$ ots $=$ C8ygQxcy4P\&sig=vi ukhpJaSCeraWBd 
6HSzB9898w\#v=onepage\&q=BUSARELLO\%2C\%20Raul\%20In\%C3\%A1cio \%2C\%20Patricia\%20Bieging\%2C\%20and\%20Vania\%20Ribas\%20Ulbricht.\% 20M\%C3\%ADdia\%20e\%20Educa\%C3\%A7\%C3\%A30\%3A\%20novos\%20olh ares\%20para\%20a\%20aprendizagem\%20sem\%20fronteiras.\%20Pimenta\%2 oCultural\%2C\%202013.\&f=false> ACESSO EM 12 jan. 2016.

CARVALHO, Marie Jane Soares, Mérion Campos Bordas, and Rosane Aragón de Nevado. "Formação de professores: pressupostos pedagógicos do curso de Licenciatura em Pedagogia/EAD." Informática na educação: teoria \& prática8.1 (2005). Disponível em < file:///C:/Users/marcelo/Downloads/968731009-1-PB\%20(1).pdf> Acesso em: 10 jan. 2016.

CERNY, Roseli Zen, and Edel Ern. "Uma reflexão sobre a avaliação formativa na educação a distância." Associação Nacional de Pós-Graduação em Educação (2001): 149-170. Disponivel em < http://www.creche.ufba.br/twiki/pub/GEC/TrabalhoAno2001/uma reflexao sob re a avaliacao formativa na ead.pdf> Acesso em: 22 fev. 2016

CHRISTANTE, L, et al. O papel do ensino a distância na educação médica continuada: Uma análise crítica. Rev. Assoc. Med. Bras. 2003; 49 (3); 326-9. Disponível em: < http://www.scielo.br/scielo.php?pid=S010442302003000300039\&script=sci_arttext> Acesso em: 05 nov. 2012.

CONGRESSO BRASILEIRO DE INFORMÁTICA EM SAÚDE. 2004, Ribeirão Preto. Ribeirão Preto, IX CBIS. p. 1-6. Disponível em: http://www.sbis.org.br/cbis9/arquivos/434.doc. Acesso: 02 nov. 2012.

Costa, K. L. D., Nilton Freire Santos, and Lourdes Mattos Brasil. "Utilizando a educação à distância na promoção da educação continuada em telemedicina." IX Congresso Brasileiro de Informática em Saúde. 2004.

COSTA, Maria Angélica, et al. "Ead e saúde: aproximação entre as áreas a partir da experiência de um curso na Fundação Oswaldo Cruz." (2012). Disponível em< http://www.arca.fiocruz.br/handle/icict/6472> Acesso em: 10 dez. 2015.

de CARVALHO, Marcelo Sávio Revoredo Menezes. A trajetória da Internet no Brasil: do surgimento das redes de computadores à instituição dos 
mecanismos de governança. Diss. UNIVERSIDADE FEDERAL DO RIO DE JANEIRO, 2006. Disponível em < https://www.researchgate.net/profile/Marcelo Carvalho17/publication/2688099 17 A TRAJETRIA DA INTERNET NO BRASIL DO SURGIMENTO DAS REDES DE COMPUTADORES INSTITUIO DOS MECANISMOS DE GO VERNANA/links/54774a430cf2a961e4825bd4.pdf> Acesso em: 15 jan. 2016

de OLIVEIRA Arieira, Jailson, et al. "Avaliação do aprendizado via educação a distância: a visão dos discentes." Revista Ensaio: Avaliação e Políticas Públicas em Educação 17.63 (2009): 313-340. Disponível em < https://www.researchgate.net/profile/Jose Fusco/publication/262738540 Lear ning evaluation of the long-

distance education the students' perspective/links/00b7d53c5462a5100700 0000.pdf > ACESSO EM: 20 jan. 2016.

de SOUZA, Amaralina Miranda, Leda Maria Rangearo Fiorentini, and Maria Alexandra Militão Rodrigues. "EDUCAÇÃO SUPERIOR A DISTÂNCIA.". Disponível em < http://forumeja.org.br/br/sites/forumeja.org.br/files/capitulo 4 CTAR 0\%20(tex to\%20basico).pdf> Acesso em: 13 dez. 2015.

de SOUZA, Paulo Nathanael Pereira. Estrutura e funcionamento do ensino superior brasileiro. Pioneira, 1991.

dos SANTOS, Vanessa Matos, and Maria Teresa Miceli Kerbauy. "Interatividade em ambiente virtual de aprendizagem: contribuições de uma experimentação." Revista Ibero-Americana de Estudos em Educação 4.3 (2010). Disponível em < http://seer.fclar.unesp.br/iberoamericana/article/view/2769/0 > Acesso em: 12 jan. 2016.

DALMAU, Marcos Baptista Lopez. Introdução à educação a distância. UFSC/DAC, 2007.

DUARTE, Zalina Maria Cancela. "EDUCAÇÃO A DISTÂNCIA (EAD): ESTUDO DOS FATORES CRÍTICOS DE SUCESSO NA GESTÃO DE CURSOS DA REGIÃO METROPOLITANA DE BELO HORIZONTE NA VISÃO 
DOS TUTORES." Belo Horizonte: Fumec(2011). Disponível em < http://www.fumec.br/anexos/cursos/mestrado/dissertacoes/completa/zalina m aria.pdf > Acesso em: 25 nov. 2015.

GASPARETO, J. Educação a Distância: Conhecendo Perfil do aluno, QUARTO congresso internacional de educação, Pesquisa e gestão. 2012

EVANGELISTA, Ely Guimarães dos Santos. "Educação e mundialização." Goiânia: UFG (1997).

FUENTES, Jorge Luis Herrera, Fátima Addine Fernández, and Jesús Lazo Machado. "Didáctica del proceso docente-educativo para el desarrollo de la práctica investigativo-laboral en las unidades docentes." Pedagogía Universitaria 10.5 (2005).

Disponível

em http://cvi.mes.edu.cu/peduniv/index.php/peduniv/article/view/350 Acesso em: 15 dez. 2015.

FUJITA, O. M. Educação a Distância, currículo e competências: uma proposta de formação online para a gestão empresarial. 2010. 284 f. Tese (Doutorado) Faculdade de Educação, Universidade de São Paulo (USP), SP, 2010. Disponível em< http://www.teses.usp.br/teses/disponiveis/48/48134/tde26042010-091608/en.php> Acesso em: 28 nov. 2015.

GADOTTI, Moacir, and Carlos Alberto Torres. "Paulo Freire." Administrador Público: A experiência de Paulo Freire na Secretaria da Educação da Cidade de São Paulo [1989-1991. In: FREIRE, Paulo. A educação na cidade. São Paulo: Cortez (1991). Disponível em< $\quad$ http://seminariopaulofreire.pbworks.com/f/unid2 ativ4paulofreire umabiobibliografia.pdf> Acesso em: 10 jan. 2016.

GARCIA, Aretio Lorenzo. "Educación a distancia hoy." Madrid: UNED (1994).

GIL, Antonio Carlos. "Como elaborar projetos de pesquisa." São Paulo 5 (2002): 61. Disponível em < http://s3.amazonaws.com/academia.edu.documents/31110279/9482 lista de revisao 1\%C2\%BA bimestre com respostas direito.pdf?AWSAccessKeyld $=$ AKIAJ56TQJRTWSMTNPEA\&Expires $=1456177997 \&$ Signature $=$ JNFWHEAI YP0Pz2zBSdq2n\%2BQPxJg\%3D\&response-content- 
disposition=inline\%3B\%20filename\%3DComo elaborar projetos de pesquis a.pdf> Acesso em: 16 out. 2015.

GIORDAN, Marcelo. "O computador na educação em ciências: breve revisão crítica acerca de algumas formas de utilização." Ciência \& Educação 11.2 (2005): 279-304.

GOUVÊA, Guaracira, and Carmen Irene Oliveira. Educação a distância na formação de professores: viabilidades, potencialidades e limites. Vieira \& Lent, 2006. Disponível em < https://dialnet.unirioja.es/servlet/articulo?codigo=5274402> Acesso em: 15 dez. 2015.

GUEDES, Gildásio. "Um checklist para avaliar uma plataforma virtual de aprendizagem." Currículos Contemporâneos: formação, diversidade e identidade em transição. Fortaleza: Editora UFC (2005).

IOSIF, R.A. A qualidade da Educação na escola pública e o comprometimento da cidadania global emancipada: Implicação para a situação de pobreza e desigualdade no Brasil, 2007. Dout. Unb - Ciências Humanas, Departamento de Serviço Social.

HARASIN, L. On line education: a new domain. In: MASON, R.; KAYE, A. (eds.).Mindweave: Communication, computers and distance, 1990.

HERMIDA, Jorge Fernando, and Claudia Ramos de Souza BONFIM. "A educação à distância: história, concepções e perspectivas." Revista HISTEDBR On-line, Campinas, n. especial (2006): 166-181. Disponível em< http://www.histedbr.fe.unicamp.br/revista/revis/Especial/Final/art11 22e.pdf> Acesso em 15 jan. 2016.

HICKEL, Melita. "A Educação a Distância e as possibilidades de inclusão (ões)." Anais do $17^{\circ}$ Congresso Internacional de Educação a Distância ABED. 2011. 
HOCHMAN, Gilberto; PIRES-ALVES, Fernando A.; TRINDADE LIMA, Nísia (Editores). A história dos trabalhadores da saúde como política pública. Ciência e Saúde ColetivaRio de Janeiro, v. 13, n. 3, p. 816-816, jun. 2008 . Disponível em:<http://www.scielo.br/scielo.php?script=sci arttext\&pid=S141381232008000300001\&lng=pt\&nrm=iso $>$ Acesso : 08 abr. 2015.

KENSKI, Vani Moreira, Gerson Pastre de OLIVEIRA, and Adriana CLEMENTINO. "Avaliação em movimento: estratégias formativas em cursos online." Avaliação da aprendizagem em educação on-line. São Paulo: Loyola(2006).

KOLLOCK, Peter. "Design Principles for Online Communities: Lessons from Early Settlements." vrais. IEEE, 1997 Disponível em < https://www.computer.org/csdl/proceedings/vrais/1997/7843/00/78430152.pdf >. Acessado em 01 jun. 2013.

KOTLER, P. Administração de marketing. São Paulo: Pearson/Prentice Hall, 2000. Disponível em $<$ http://www.sintracoopsc.com.br/wpcontent/uploads/2009/03/PDF-Marketing-Kotler-2000.pdf> Acesso em 15 jan. 2016.

KUBO, Olga Mitsue, and Sílvio Paulo Botomé. "Ensino-aprendizagem: uma interação entre dois processos comportamentais." Interação em Psicologia $\begin{array}{lllll}\text { (Qualis/CAPES: } & \text { A2) } 5.1 & \text { (2001). Disponível em < }\end{array}$ http://ojs.c3sl.ufpr.br/ojs/index.php/psicologia/article/viewArticle/3321> Acesso em: 19 nov. 2015.

LACERDA, Maria Ribeiro, and Regina G. Santini Costenaro. "O cuidado como manifestação do ser e fazer da enfermagem." Santa Maria: Vidya 1.1 (1999).

LAGO, F.; SILVA, E.P.V.; VIEIRA, T.A. ATUAÇÃO DO ENFERMEIRO NAS DIVERSAS ÁREAS NO ÂMBITO INTRA E EXTRA-HOSPITALAR, 2009. DISPONÍVEL EM http://www.abeneventos.com.br/anais_61cben/files/02323.pdf> ACESSO EM: 10 jan. 2016. 
LARA, E. Artigo por Colunista Portal. EaD - Vantagens da Educação a Distância, 02/2009.

Disponível:

https://www.portaleducacao.com.br/pedagogia/artigos/7671/ead-vantagensda-educacao-a-distancia. Acesso em: 04 mar. 2015.

LEGISLAÇÃO EM EAD DISTRITO FEDERAL Fonte: Normas para o sistema de ensino do Distrito Federal Conselho de Educação do Distrito Federal, 2009.

LEMOS, José Carlos Galvão. "Do encanto ao desencanto, da permanência ao abandono: o trabalho docente e a construção da identidade profissional." Unpublished doctoral thesis). 2009 Pontifícia Universidade Católica, São Paulo. Disponivel em http://revistaescola. abril. com. br/gestaoescolar/tese jose lemos. pdf Acesso em: 08 out. 2015.

LÉVY, Pierre. As tecnologias da inteligência: o futuro do pensamento na era da informática. São Paulo: Editora 34, 1995.

LEVY, Pierre. "O futuro da internet: em direção a uma ciberdemocracia planetária. São Paulo: Paulus, 2010. _." Cibercultura. São Paulo: Editora 34 (1999).

LINARD, Monique. "New debates on learning support." Journal of Computer Assisted Learning 11.4 (1995): 239-253. Disponível em < http://onlinelibrary.wiley.com/doi/10.1111/j.1365-

2729.1995.tb00140.x/abstract> Acesso em: 17 out. 2015.

LUZZI, Daniel Angel. O papel da educação a distância na mudança de paradigma educativo: da visão dicotômica ao continuum educativo. Diss. Universidade de São Paulo, 2007. Disponível em < http://www.teses.usp.br/teses/disponiveis/48/48134/tde-09102007090908/en.php> Acesso em: 27 jan. 2014.

MACHADO, Liliana Dias, and Elian de Castro MACHADO. "O papel da tutoria em ambientes de EAD." Universidade Federal do Ceará (2004). Disponível em<http://nead.uesc.br/arquivos/Biologia/scorm/O_PAPEL_DA_TUTORIA_E M_AMBIENTES_DE_EAD.pdf> Acesso em 30 jan. 2016. 
MACHADO, Glaucio José Couri. "Educação e ciberespaço: estudos, propostas e desafios." (2010). Disponível em < http://bibliodigital.unijui.edu.br:8080/xmlui/bitstream/handle/123456789/1798/E ducacao\%20e\%20ciberespaco.pdf?sequence=1> Acesso em: 13 jan. 2016 MAIA, C. e MATTAR, J. ABC da EaD: educação a distância hoje. São Paulo: 2010. Disponível em: $<$ http://publicacoes.unigranrio.edu.br/index.php/magistro/article/viewFile/1197/ 801>. Acesso em: 09 jan. 2013.

MAIA, C.; MATTAR, J. ABC da EAD: a educação a distância hoje. São Paulo: Pearson Prentice Hall, 2007.

MAIA, Marta de Campos. O uso da tecnologia de informação para a educação a distância no ensino superior. Diss. 2003. Disponível em< http://bibliotecadigital.fgv.br/dspace/handle/10438/2463> Acesso em: 14 nov. 2014.

MALACRIDA, Vanessa Ananias, and HF de BARROS. "A Ação Docente no Século XXI: Novos Desafios." Colloquium Humanarum. Vol. 8. 2011 Disponível em< http://www.unoeste.br/site/pos/enapi/2011/suplementos/documentos/Humanar um-PDF/CDEduca\%C3\%A7\%C3\%A30.pdf\#page=4> Acesso em: 25 out. 2013.

MARCUZZO, MARLEI, et al. "A SATISFAÇÃO DOS ALUNOS DE EDUCAÇÃO A DISTÂNCIA: UM ESTUDO DE CASO APLICADO EM NÍVEL DE GRADUAÇÃO E PÓS-GRADUAÇÃO DE UMA UNIVERSIDADE FEDERAL." (2015).

Disponível em https://repositorio.ufsc.br/handle/123456789/135941> Acesso em: 15 jan. 2016.

Marks, Ronald B., Stanley D. Sibley, and J. B. Arbaugh. "A structural equation model of predictors for effective online learning." Journal of Management Education $29.4 \quad$ (2005): 531-563.. $\quad$ Disponível em< http://jme.sagepub.com/content/29/4/531.short> Acesso em: 12 out. 2015. 
MATTAR, João. "Design Educacional: educação a distância na prática." São Paulo: Artesanato Educacional (2014).

MATTEI, Rejane E.V.As percepções dos professores do ensino superior, na modalidade a distância sobre suas atividades docentes. Dissertação de Mestrado. Universidade do Estado de Santa SANTOS- UDESC, Florianópolis, SC 2012.

Disponível:

http://www.faed.udesc.br/arquivos/id submenu/151/rejane esther vieira matt ei.pdf. Acesso em: 07 mai. 2015.

Melo, Ana Cristina. "Desenvolvendo Aplicações com UML - Do conceitual a implementação." Brasport, Rio de Janeiro (2002).

MELO, Luci Ferraz de. "EAD e interatividade-conceitos em evolução." Rumores-Revista de Comunicação, Linguagem e Mídias 2.3 (2009).

MENDES, Eugênio Vilaça. "As redes de atenção à saúde." Brasília: Organização Pan-Americana da Saúde 549 (2011). Disponível em < http://www.scielo.br/pdf/csc/v15n5/v15n5a05> Acesso em: 28 out. 2013.

MENDES NETTO, Cristiane; PERPÉTUO, Denise Graciolli A. Martins. Estratégias para construção de relações afetivas em ambientes virtuais de aprendizagem. In: CONGRESSO INTERNACONAL DE EDUCAÇÃO A DISTÂNCIA, 16., 2010, Foz do Iguaçu. Anais... Foz do Iguaçu: ABED, 2010. 10p. Disponível em: < www.abed.org.br/congresso2010/cd/252010085045.pdf $>$ Acesso em: 15 jan. 2013.

Mercado, Luis Paulo Leopoldo. Práticas de formação de professores. UFAL, 2008. Disponível em < https://books.google.com.br/books?hl=pt$B R \& \mid r=\& i d=L v n I E \_8 T U 8 E C \& o i=f n d \& p g=P A 9 \& d q=M E R C A D O,+L u i s+P a u l o+L$ eopoldo.+Pr\%C3\%A1ticas+de+forma\%C3\%A7\%C3\%A30+de+professores.+U $\mathrm{FAL},+2008$.\&ots=R97Xo5PMKM\&sig=0ldUcjwKCno65anqcbzNX72HvW4\#v=0 nepage\&q=MERCADO\%2C\%20Luis\%20Paulo\%20Leopoldo.\%20Pr\%C3\%A1t icas\%20de\%20forma\%C3\%A7\%C3\%A30\%20de\%20professores.\%20UFAL\% 2C\%202008.\&f=false > Acesso em: 27 nov. 2015. 
Mezzari, Adelina, et al. "O uso do Moodle como reforço ao ensino presencial de parasitologia e micologia no curso de graduação em medicina." Revista brasileira de educação médica= Brazilian journal of medical education. Vol. 36, $\quad$ n. 4 (2012), p. 557-563 (2012). Disponível em < http://www.scielo.br/pdf/rbem/v36n4/16.pdf> Acesso em 16 jan. 2016.

Ministério da Educação. 1998. Decreto Lei №2.494, de 10/02/1998. Disponível em: < http://www.mec.gov.br/Sesu/ftp/dec_2494.doc >. Acesso em 17 out. 2013.

MOORE, Michael G.; KEARSLEY, Greg. Educação a distância: uma visão integrada - Edição especial ABED - Associação Brasileira de Educação a Distância. São Paulo: Thomson Learning, 2007. Disponível: http://joaomattar.com/blog/2007/09/21/a-educacao-a-distancia-uma-visaointegrada/ Acesso em: 10 jan. 2015.

MOORE, Michael. Teoria da Distância Transacional. In : KEEGAN, D. Theoretical Principles of Distance Education. London : Routledge, 1993, p. 2238. Trad. De Wilson Azevedo. Publicado em Revista Brasileira de Aprendizagem Aberta e a Distância. Disponível em< www.abed.org.br/publique> Acesso em: 24 abr. 2015.

MORAN, José Manuel. "O Que é Educação a Distância?" In Boletim de Educação a Distância. Brasil, Ministério da Educação, Secretaria de Educação a Distância, 2007. Disponível em: www.eca.usp.br/prof/moran Acesso em: 10 nov. 2013.

MOURA, Eliane das Neves. A Orientação Acadêmica na Educação a Distância: percepções dos sujeitos envolvidos no processo. Dissertação, Instituto de Educação da Universidade Federal de Mato Grosso, 2002.

MOZZER, Luciene Domenici. "Ambientes virtuais de aprendizagem: conceitos e estratégias de comunicação." Biblioteca virtual do NEAD/UFJF. Disponível em http://www. cead. ufff. br/media/biblioteca/ambientes_virtuais_conceitos. pdf > Acesso em: 15 abr. 2014. 
NEDER, M.L.C. Educação Aberta e a Distância: concepções e modelos. 1. Fascículo do Curso de Especialização em EAD para Formação de Orientadores Acadêmicos. Cuiabá: UFMT, 1999.

NEDER, Maria Lucia Cavalli. "A formação do professor a distância: diversidade como base conceitual." UFMT, Cuibá (1999).

NERY, Belmayr Knopki. O ciclo de desenvolvimento do professor e o sistema de atividade aprendizagem on-line em um curso de especialização em ensino de ciências. Diss. Universidade de São Paulo, 2014. Disponível em< http://www.teses.usp.br/teses/disponiveis/48/48134/tde-25092014105451/en.php> Acesso em: 13 out. 2015.

NETTO, Carla, Viviane GUIDOTTI, and Pricila Kohls SANTOS. "A evasão na EaD: investigando causas, propondo estratégias." Anais da Segunda Conferencia Latinoamericana sobre el abandono en la Educacion Superior. 2012. Disponível em <http://www.alfaguia.org/wwwalfa/images/ponencias/clabesII/LT 1/ponencia completa 26.pdf> Acesso em 18 fev. 2016.

NISKIER, Arnaldo. "Educação a distância: a tecnologia da esperança." São Paulo: Loyola 2001 (1999).

NUNES, I. B. (1992) Noções de Educação a Distância. Acesso em: 10 de Agosto de 2012.

NUNES, Ivônio Barros. "Noções de educação a distância." Revista educação à distância 4.5 (1993): 7-25.

NUNES, Renata Cristina. "A avaliação em educação a distância é inovadora? Uma reflexão." Estudos em Avaliação Educacional23.52 (2012): 274-299. Disponível em http://publicacoes.fcc.org.br/ojs/index.php/eae/article/view/1940> Acesso em: 18 jan. 2016. 
O Jornal Data Folha, Disponível: http://www1.folha.uol.com.br/especial/2014/saudedobrasil/ Acesso em: 10 abr. 2015.

OLIVEIRA, Elsa Guimarães. Educação a distância na transição paradigmática. Papirus Editora, 2003. Disponível em < https://books.google.com.br/books?hl=pt-

$B R \& \mid r=\& i d=N D K \_p x c N h S 0 C \& o i=f n d \& p g=P A 71 \& d q=O L I V E I R A,+E .+G .+E d u c a$ \%C3\%A7\%C3\%A3o+a+dist\%C3\%A2ncia+na+transi\%C3\%A7\%C3\%A3o+par adigm\%C3\%A1tica.+Campinas:+Papirus, $+2003 . \& o t s=w p v Y i 9 p C H 6 \& s i g=V \_T$ FLLTBkVDUILJiNXOPBvv53S4\#v=onepage\&q\&=false> Acesso em: 18 jan. 2016.

OLIVEIRA, Gleyva Maria S. de. "O perfil de tutoria nos projetos de cursos a distância voltados para a formação de professores do Ensino Fundamental." Cuiabá: Nead/UFMT (2003).

OLIVEIRA, M. A. N. (2007). Educação à Distância como Estratégia para a Educação Permanente em Saúde: Possibilidades e Desafios. Revista Brasileira de Enfermagem, v. 60, n. 5, p. 585-589. Disponível em: <http://www.scielo.br/scielo.php?script=sci_arttext\&pid=S0034$71672007000500019>$ Acesso em: 11 nov. 2013.

OLIVEIRA, Marluce Alves Nunes. "Educação à Distância como estratégia para a educação permanente em saúde: possibilidades e desafios." Rev bras enferm60.5 (2007): 585-9.

OLIVEIRA, Terezinha. "Ética e conhecimento na formação da pessoa (professor): uma abordagem no âmbito da História da Educação." Revista Diálogo Educacional 12.36 (2012): 427-446. Disponível em < file://C:/Users/marcelo/Downloads/dialogo-6094\%20(1).pdf> Acesso em: 24 jan. 2016.

PACHECO, Paulo Bernardo de Magalhães. "Os discursos e as práticas no ensino e aprendizagem da História: representações de professores e alunos do ensino secundário." (2014). Disponível em < 
http://repositorium.sdum.uminho.pt/handle/1822/34192> Acesso em: 15 out. 2014.

PACHECO, Laíssa Rodrigues Esposti, and Cristiano Farias Coelho. "O MATERIAL DIDÁTICO IMPRESSO COMO FACILITADOR NA EDUCAÇÃO A DISTÂNCIA." SIED: EnPED-Simpósio Internacional de Educação a Distância e Encontro de Pesquisadores em Educação a Distância 2012(2012). Disponível em

http://sistemas3.sead.ufscar.br/ojs/index.php/sied/article/view/220> Acesso em: 15 out. 2014.

de PAIVA, Marlúcia Menezes. "As primeiras iniciativas da Teleducação no Brasil: os Projetos SACI e EXERN." Revista Educação em Perspectiva 4.2 (2013).

Disponível em

http://www.seer.ufv.br/seer/educacaoemperspectiva/index.php/ppgeufv/article/ view/428>Acesso em: 20 dez. 2015.

PALLOF, Rena M., and Keith PRATT. "Estimulando a aprendizagem colaborativa." Construindo Comunidades de Aprendizagem no Ciberespaço: estratégias eficientes para salas de aula on-line. Porto Alegre: Artmed (2002).

PALLOF, Rena M., et al. Construindo comunidade de aprendizagem no ciberespaço: estratégias eficientes para salas de aula on-line. Artmed, 2002.

PEIXOTO, H.; Peixoto, M.; Alves, E. Estratégias de aprendizagem utilizadas por graduandos e pós-graduandos em disciplinas semipresenciais da área de saúde Rev. Latino-Am. Enfermagem 20(3):[8 telas] maio-jun. 2012 Disponível em < www.eerp.usp.br/rlae> Acesso em: 20 mar.2013.

Perez, Francisco Gutierrez, and Daniel Prieto. A mediação pedagógica: educação a distância alternativa. Papirus, 1994.

PLENS, C. C.; A AVALIAÇÃO NO PROCESSO DE ENSINO E APRENDIZAGEM. IX Workshop Multidisciplinar sobre Ensino e Aprendizagem WEA' 2012/2013 Faculdade Campo Limpo Paulista. 2013. Disponível em< http://www.faccamp.br/wea/anteriores/revista2012-2013.pdf> Acesso em 18 jan. 2016. 
PORTAL MINISTÉRIO DA EDUCAÇÃO; Secretaria de Educação a Distância.

Disponível:<http://portal.mec.gov.br/index.php?option=com content\&view=article\&id=289\&ltemid=822>. Acesso em: 11 nov. 2012.

PORTAL MINISTÉRIO DA EDUCAÇÃO. Legislação da Educação a Distância. Disponível em: <http://portal.mec.gov.br/index.php?option=com_

PORTAL MINISTÉRIO DA EDUCAÇÃO. Secretaria de Educação a Distância. Disponível em:

<http://portal.mec.gov.br/index.php?option=com_content\&view=article \&id=289\&ltemid=822>. Acesso em: 10 nov. 2012.

POSSOLI, GE. "Educação a distância nas instituições de educação superior: análise de tendências para a educação superior no Brasil." Encontro Sul Brasileiro de Psicopedagogia 3 (2009). Disponível em< http://www.pucpr.br/eventos/educere/educere2009/anais/pdf/2558_1547.pdf> Acesso em: 22 mar. 2014.

POSSOLLI, Gabriela Eyng, and Priscila de Quadros CURY. "Reflexões sobre a elaboração de materiais didáticos para educação a distância no Brasil." IX Congresso Nacional de Educação-EDUCERE/III Encontro Sul Brasileiro de Psicopedagogia. 2009.

PRETI, OO, and Gleyva OLIVEIRA. "Estado da Arte sobre "Tutoria": modelos e teorias em construção." PRETI, O.; OLIVEIRA, GMS O sistema de Orientação Acadêmica no curso de Pedagogia a distância da Universidade Federal de Mato Grosso. Relatório de Pesquisa. Programa CAERENADTéléuniversité du Québec, Canadá(2003). Disponível em< http://www.uab.ufmt.br/uab/images/artigos_site_uab/tutoria_estado_arte.pdf> Acesso em: 24 out. 2015.

PRETI, Oreste. "Educação a Distância: uma prática educativa mediadora e mediatizada." Educação a Distância: inícios e indícios de um percurso. NEAD/IE/UFMT. Cuiabá: UFMT(1996). Disponível em< http://www.uab.ufmt.br/uploads/pcientifica/ead_pratica_educativa.pdf> Acesso em: 24 jan. 2016. 
Revista Vozes dos Vales da UFVJM. Disponível em: http://site.ufvjm.edu.br/revistamultidisciplinar/ 2013 Acesso em: 07 mai. 2015 RIBEIRO, Elvia Nunes, GA de A. Mendonça, and Alzino Furtado Mendonça. "A importância dos ambientes virtuais de aprendizagem na busca de novos domínios da EAD." Congresso da Associação Brasileira de Educação a Distância, Goiás. Disponível em< http://www. abed. org. br/congresso2007/tc/4162007104526am. Pdts 2007. Acesso em: 25 jan. 2016 RIBEIRO NETO, J. B. M.; TAVARES, J. C.; HOFFMANN, S. C. Sistemas de gestão integrados. São Paulo: SENAC, 2008.

ROMISZOWSKI, A., and H. ROMISZOWSKI. "Dicionário de Terminologia de Educação a Distância. 1997." Educação a Distância (2003).

ROSADO, Luiz Alexandre da Silva, and Vitor Manuel Nabais Tomé. "As redes sociais na internet e suas apropriações por jovens brasileiros e portugueses em idade escolar." Revista Brasileira de Estudos Pedagógicos 96.242 (2015): 11-25. Disponível em< http://www.scielo.br/pdf/rbeped/v96n242/2176-6681rbeped-96-242-00011.pdf> Acesso em: 26 jan. 2016.

ROTTA, Mariza, Cristiana Bezerra dos Santos, and Giseli Baranoski Brasil. "Uma análise sobre a educação à distância como instrumento de politicas educacionais voltadas para formação de professores/Un análisis acerca de la educación a distancia como instrumento de políticas educacionales dirigidas a la formación de profesores." Actualidades Investigativas en Educación14.1 (2014).

Disponível

em< http://www.revistas.ucr.ac.cr/index.php/aie/article/view/13216> Acesso em: 23 jan. 2016.

SALES, Mary Valda Souza. "Uma reflexão sobre a produção do material didático para EaD." Anais do XII Congresso Internacional de Educação a Distância, $\quad$ ABED. 2005. Disponível em < http://www.abed.org.br/congresso2005/por/pdf/044tcf5.pdf> Acesso em: 18 dez. 2015. 
SANTANA, Fabiana Ribeiro, et al. "Educação à distância nas instituições federais de ensino superior: a situação da enfermagem brasileira." Revista Eletrônica de Enfermagem7.1 (2006). Disponível em < https://www.revistas.ufg.br/index.php?journal=fen\&page=article\&op=view\&pat h\%5B\%5D=862\&path\%5B\%5D=1036 >Acesso em: 20 jan. 2015.

SANTOS, Joao Francisco Severo. "Avaliação no ensino a distância." Revista Iberoamericana de Educación 38.4 (2006): 6 . Disponivel em < https://dialnet.unirioja.es/servlet/articulo?codigo=1704264> Acesso em: 10 jan. 2016

SANTOS, Catarina de Almeida. A expansão da educação superior rumo à expansão do capital: interfaces com a educação à distância. Diss. Universidade de São Paulo, 2008. Disponível em< http://www.teses.usp.br/teses/disponiveis/48/48134/tde-25092009163728/en.php > Acesso em: 26 nov. 2014.

SANTOS, Lenir; MONTI, José Fernando Casquel. É preciso desjudicializar a saúde como uma das medidas de salvação do SUS. II Jornada de Direito da Saúde. CNJ, São Paulo, 19/05/2015. Disponível: http://www.idisa.org.br/img/File/JUDICIALIZA\%C3\%87\%C3\%830\%20DA\%20 SA\%C3\%9ADE.pdf Acesso em 09 jun. 2015.

SANTOS, W. "A utilização de imagens na construção do material didático na EaD." R. N., Linhares (Org.). Anais do $3^{\circ}$ Simpósio de Educação e Comunicação (2012): 229-240.

SANTOS, Carlene Porto. "DESAFIOS DO ENSINO EM EAD." MaiêuticaCurso de Serviço Social1.1 (2015). Disponível em< https://publicacao.uniasselvi.com.br/index.php/SES_EaD/article/view/526> Acesso em: 24 jan. 2016.

SEIXAS, Carlos Alberto, et al. "Ambiente virtual de aprendizagem: estruturação de roteiro para curso online." Rev bras enferm [Internet] (2012): 660-6.

Disponível em $<$ http://gruposdepesquisa.eerp.usp.br/gepecopen/publicacoes/87035d8c10146d 9c11bd9f47058d8ab9.pdf > Acesso em : 12 jan. 2016. 
SILVA, CJP, LEMC OLIVEIRA, and W. P. Camara. "UM ESTUDO DE IMPLANTAÇÃO DE UM SISTEMA DE GESTÃO DE APRENDIZAGEM DE CÓDIGO ABERTO PARA CURSOS DE EDUCAÇÃO A DISTÂNCIA: MOODLE-UM ESTUDO DE CASO." Disponível em < http://www.unibratec.edu.br/tecnologus/wp-

content/uploads/2010/12/silva_oliveira_camara.pdf> Acesso em: 15 jan. 2016

SILVA, SH da. "Controle da qualidade assistencial de enfermagem: implementação de um modelo." São Paulo (SP): Escola de Enfermagem de Ribeirão Preto/USP (1994).

SILVEIRA, Sidnei Renato, et al. "Alternativas para Construção de Objetos de Aprendizagem: um estudo de caso voltado à definição de uma arquitetura para adaptação de cursos na modalidade de Educação a Distância." RCTRevista de Ciência e Tecnologia 1.1 (2015). Disponível em< http://saes2010.ufrr.br/index.php/rct/article/view/2498> Acesso em: 10 jan. 2016.

SODER, R. Cronologia Histórica da Saúde Pública, 2011. Brasília, DF. Disponível: < http://www.funasa.gov.br/site/museu-da-funasa/cronologiahistorica-da-saude-publica/> Acesso em: 23 out. 2015.

SOFFENER, R. Avaliação da aprendizagem em curso a distancia. São Paulo, 2010. Tese de Doutorado; Faculdade de Educação da Universidade de São Paulo.

Disponível:

www.teses.usp.br/teses/disponiveis/48/.../ROSEMARY SOFFNER.pdf Acesso em : 15 fev. 2015.

SOUZA, et all. Educação superior a distância: Comunidade de Trabalho e Aprendizagem em Rede (CTAR) / Amaralina Miranda de Souza, Leda Maria Rangearo Fiorentini e Maria Alexandra Militão Rodrigues, organizadoras. Brasília: Universidade de Brasília, Faculdade de Educação, Editora da Universidade de Brasília, 2010. 264 p.

SOUZA, Helcimara Affonso, et al. "DESAFIOS NA GESTÃO DA EAD: PROPOSTA DE ESTRUTURAÇÃO DE POLOS MODELOS COMO UNIDADES GESTORAS." Gestão e Saúde 1.1 (2012): pag-1455. Disponivel 
emhttp://gestaoesaude.unb.br/index.php/gestaoesaude/article/view/341/0 Acesso em: 10 fev. 2016

TORI, Romero. Educação sem distância: as tecnologias interativas na redução de distâncias em ensino e aprendizagem. São Paulo: Senac, 2010. 256 p. ISBN 85-7359-921-9.

TOZZI, Jocelita Giordani. "O serviço de orientação acadêmica na licenciatura plena em educação básica-modalidade a distância: um estudo de caso. 2002."Monografia (Especialização)-Instituto de Educação, Universidade Federal de Mato Grosso, UFMT, Cuiabá, MT (2002).

Unb cursos a distância Disponível em $<$ http://www.unb.br/aluno de graduacao/cursos a distancia $>$ Acesso em: 02 fev. 2015.

UNIFESP Virtual. 2004. [on line]. Disponível em: <http://www.virtual.unifesp.br/home/posgradua.php> Acesso em: 20 nov. 2014 VASCONCELOS, Raíza Texeira Griffo, et al. "PERFIL DOS DISCENTES DA PRIMEIRA TURMA DO CURSO PRÉ-VESTIBULAR SOCIAL TEOREMA NA MODALIDADE A DISTÂNCIA." Disponivel em < http://www.filologia.org.br/rph/ANO21/63supl/0124.pdf> Acesso em: 15 fev. 2016

VALENTE, José Armando, Maria Elisabette B. Brito Prado, and Maria Elizabeth Bianconcini de Almeida. "Educação a distância via internet." Educação a distância via Internet. Avercamp, 2003. Disponível em < http://bases.bireme.br/cgi-

bin/wxislind.exe/iah/online/?IsisScript=iah/iah.xis\&src=google\&base=LILACS\&I ang=p\&nextAction=Ink\&exprSearch=707976\&indexSearch=ID> Acesso em: 18 jan. 2016.

VIDAL, Eloísa Maia, and José Everardo Bessa Maia. "Introdução a educação a distancia." Fortaleza, $\quad C E: \quad R D S(2010)$. Disponível $\quad$ em< file://C:/Users/marcelo/Downloads/LIVRO\%20\%20INTRODUCAO\%20A\%20EDUCACAO\%20A\%20DISTANCIA\%20\%20UNIDADE1\%20-1\%20(1).pdf> Acesso em: 15 jan. 2016 
VIEIRA, Ana Beatriz Duarte; Alves, Elioenai Dornelles; Kamada, Ivone. Cuidar, cuidando-se e mantendo a chama acesa em nós. Universidade de Brasília-UnB. Núcleo de Estudos em Educação e Promoção da saúde NESPROM/UnB. Brasília, DF, 2014.

VILAÇA, M. (2010). Educação a distância e Tecnologias: conceitos, termos e um pouco de história. Disponível em: < http://publicacoes.unigranrio.edu.br/index.php/magistro/article/viewFile/1197/8 01> Acesso em: 10 nov. 2012.

Yacef, Kalina. "Intelligent teaching assistant systems." Computers in Education, 2002. Proceedings. International Conference on. IEEE, 2002. Disponivel em

http://ieeexplore.ieee.org/xpl/login.jsp?tp=\&arnumber=1185885\&url=http\%3A \%2F\%2Fieeexplore.ieee.org\%2Fxpls\%2Fabs all.jsp\%3Farnumber\%3D11858 85> Acesso em: 10 fev. 2016

WAQUIL, M. P. ; ZANK, C. ; OLIVEIRA, J. R. ; XAVIER, R. T. O. ; OLIVEIRA, W. F. . Educação a distância e comunidades virtuais de aprendizagem: novos espaços, novas possibilidades. Competência (Porto Alegre), v. 2, p. 8, 2009.

ZAMLUTTI, Maria Esmeralda Mineu. "Uma análise do surgimento da educação à distância no contexto sociopolítico brasileiro no final da década de 30 e início da década de 40." (2006). Disponível em < http://www.bibliotecadigital.unicamp.br/document/?code=vtls000383638> Acesso em: 22 nov. 2015.

https://www.revistaensinosuperior.gr.unicamp.br/notas/mulheres-sao-maioriacom-nivel-superior-mas-homens-dominam-mercado-de-trabalho acesso em 14 fev. 2016.

http://www.ibge.gov.br/home/estatistica/populacao/trabalhoerendimento/pnad2 009/ acesso em 14 fev. 2016.

http://www.brasil.gov.br/educacao/2016/01/metade-das-vagas-em-cursofederais-atende-alunos-de-escolas-publicas acesso 16 fev. 2016. 
http://universidades.universia.com.br/universidades-brasil/historia-ensinosuperior/ acesso em 30 jan. 2015.

www.matriculaweb.unb.br acesso em 14 fev. 2016.

https://www.revistaensinosuperior.gr.unicamp.br/notas/ mulheres-sao-maioriacom-nivel-superior-mas-homens-dominam-mercado-de-trabalho acesso em 14 fev. 2016

(http://www.ibge.gov.br/home/estatistica/populacao/trabalhoerendimento/pnad 2009/) acesso em 14 fev. 2016

http://www.dicionarioinformal.com.br/pesquisa+quantitativa/ acesso em 23 fev. 2016 